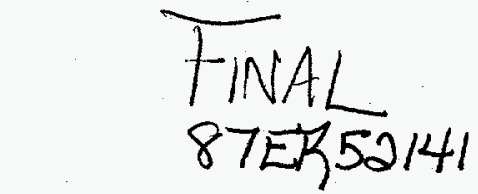

GTFR-119

DOEFR/52141--TH

\title{
RADIOACTIVE WASTE DISPOSAL CHARACTERISTICS OF CANDIDATE TOKAMAK DEMONSTRATION REACTORS
}

\author{
E.A. Hoffman \\ W.M. Stacey \\ N.E. Hertel
}

Fusion Research Center and

Nuclear Engineering Program

Georgia Institute of Technology

Atlanta, Georgia 30332-0225 USA

August, 1995

\begin{abstract}
Results from the current physics, materials and blanket R\&D programs are combined with physics and engineering design constraints to characterize candidate tokamak demonstration plant (DEMO) designs. Blanket designs based on the principal structural materials, breeding materials and coolants being developed for the DEMO were adapted from the literature. Neutron flux and activation calculations were performed, and several radioactive waste disposal indices were evaluated, for each design. Of the primary low-activation structural materials under development in the US, it appears that vanadium and ferritic steel alloys, and possibly silicon carbide, could lead to DEMO designs which could satisfy realistic low-level waste (LLW) criteria, provided that impurities can be controlled within plausible limits. Allowable LLW concentrations are established for the limiting alloying and impurity elements. All breeding materials and neutron multipliers considered meet the LLW criterion.
\end{abstract}




\section{DISCLAIMER}

This report was prepared as an account of work sponsored by an agency of the United States Government. Neither the United States Government nor any agency thereof, nor any of their employees, makes any warranty, express or implied, or assumes any legal liability or responsibility for the accuracy, completeness, or usefulness of any information, apparatus, product, or process disclosed, or represents that its use would not infringe privately owned rights. Reference herein to any specific commercial product, process, or service by trade name, trademark, manufacturer, or otherwise does not necessarily constitute or imply its endorsement, recommendation, or favoring by the United States Government or any agency thereof. The views and opinions of authors expressed herein do not necessarily state or reflect those of the United States Government or any agency thereof. 


\section{DISCLAIMER}

Portions of this document may be illegible electronic image products. Images are produced from the best available original document. 


\section{INTRODUCTION}

The long-term objective of fusion research is to develop an environmentally benign energy source with a virtually inexhaustible fuel supply. Since the product of the fusion reaction (helium in the case of DT fusion) is environmentally benign (and has economic value), and since the halflife of the radioactive tritium fuel is 12.5 years, the environmental benignity will depend on the neutron activation characteristics of the materials of which the fusion reactors will be constructed. In particular, the environmental benignity will depend on the decay rate of neutron-transmuted radioisotopes which emit high energy gamma rays and on the consequent implications for the radioactive waste disposal of components upon removal from the reactor or upon decommissioning of the plant at end of life. The current experience with fission reactor radioactive waste disposal suggests that societal concerns about longterm (millennia) burial of high-level radioactive waste (HLW) in deep geological repositories would destroy the public image of the environmental benignity of fusion if fusion reactors produced high-level radioactive waste, no matter the technical soundness of high-level radioactive waste disposal technology nor the technical distinctions between activated structural materials that must be stored for thousands of years and fission products and actinides which must be stored for hundreds of thousands of years. The societal image of fusion as an environmentally benign energy source, hence a major motivation for the development of fusion, would seem to depend on fusion reactors being constructed of materials with neutron activation properties such that the radioactive waste from fusion reactors would qualify as low-level waste (LLW) that could be disposed of by burial in near-surface repositories. Variants of this viewpoint are held by many people in the fusion community, particularly in the US, and there are R\&D programs to develop low-activation materials.

Our purpose in this paper is to extrapolate the present understanding from the fusion physics and technology R\&D programs to predict the radioactive waste disposal characteristics of fusion demonstration reactors (DEMOs), which might be constructed in the 2025-2050 time frame. The status and anticipated future progress of the tokamak physics data base for a DEMO has been discussed in Ref. 1 , and we use the intermediate advanced tokamak mode defined in that document as a physics design base for DEMO. The US fusion program is developing vanadium and ferritic steel alloys and silicon carbide as candidate low activation structural materials for DEMO, and a martensitic steel is being developed for DEMO in Europe. A number of austenitic steels are either available or under development in the event that these advanced materials $R \& D$ programs are not successful. Recent first-wall/blanket designs based on all of these structural materials and a variety of coolant and breeder options are available in the literature ${ }^{2-5}$, and we adapt these first-wall and blanket designs for our DEMO designs. Otherwise, technology that is being developed for ITER ${ }^{6}$ is adopted for our DEMO designs. The different thermal-mechanical properties of 
the different structural materials and the different tritium breeding capabilities of the different breeding materials lead to significant differences in the dimensions of components and overall size of the different DEMO reactors, which in turn affects the neutron activation rates and waste disposal characteristics. The waste disposal characteristics of the different DEMO designs are established by calculating neutron activation rates and the resulting dose rates as a function of time after removal from the reactor or decommissioning, then evaluating several possible waste disposal indices for comparison with LLW criteria. Since no generally accepted LLW criterion exists for fusion wastes, we compared with several international criteria in use for various types of radioactive waste.

The paper is organized as follows. The development of the DEMO design characteristics is described in section II, and the waste disposal evaluation of these designs is discussed in section III. Conclusions are presented in section IV. Materials properties and compositions used in this work are discussed in appendix $A$, specific activity limits for fusion-relevant radioisotopes are given in appendix $B$, elemental contributions to the Waste Disposal Rating are given in appendix $C$, and a detailed discussion of waste disposal characteristics of the candidate DEMO designs is given in appendix $D$.

\section{DEMO DESIGNS}

\section{II.A. Reference Blanket Designs}

The principal blanket design options being developed for the DEMO in the United States, Japan, and Europe were chosen as the basis for the reference designs. These reference designs were based on 1) a ferritic steel/water/lithium oxide/beryllium blanket design, 2) a martensitic steel/water/lithium lead blanket design, 3) a vanadium/lithium blanket design, and 4) a silicon carbide/helium/ lithium zirconate/beryllium blanket design. In addition, several variants of the structure/water/lithium oxide/beryllium blanket design with different structural materials were considered for purposes of comparison. The materials compositions and thermo-mechanical properties are given in appendix A.

\section{II.A.1. Reference $\mathrm{FeS} / \mathrm{Li}_{2} \mathrm{O} / \mathrm{H}_{2} \mathrm{O}$ Blanket Design (R1)}

Mori et al. ${ }^{2}$ have developed a blanket design that is water-cooled and uses a ferritic steel (FeS) structure, a solid lithium oxide $\left(\mathrm{Li}_{2} \mathrm{O}\right)$ breeder and beryllium (Be) neutron multiplier. The first wall is a FeS tube bank cooled with pressurized water $\left(\mathrm{H}_{2} \mathrm{O}\right)$. Behind the first wall is a replaceable breeding blanket which consists of solid $\mathrm{Li}_{2} \mathrm{O}$ pebbles, a Be multiplying region and intermittent FeS cooling tubes and support structure. Behind the replaceable blanket is a permanent breeding blanket intended to last the life of the plant. 
II.A.2. Reference $\mathrm{MS} / \mathrm{Li}_{17} \mathrm{~Pb}_{83 /} \mathrm{H}_{2} \mathrm{O}$ Blanket Design (R2)

Giancarli et al. ${ }^{3}$ have developed a blanket design for DEMO using a martensitic steel (MS) referred to as Martensite for NET (MANET). The first wall design consists of a MANET tube bank cooled by pressurized water. The blanket is constructed of MANET structure, liquid lithium lead $\left(\mathrm{Li}_{17} \mathrm{~Pb}_{83}\right)$ breeder, and pressurized water in MANET coolant tubes. The $\mathrm{Li}_{17} \mathrm{~Pb}_{83}$ is circulated slowly to extract the tritium.

\section{II.A.3 Reference V/Li Blanket Design (R3)}

Ehst et al." have developed a liquid lithium-cooled blanket design using a vanadium (V) alloy for the structural material. The first wall is a slab of vanadium alloy with lithium $(\mathrm{Li})$ coolant flowing behind it. The blanket consists of lithium flowing through coolant channels defined by the vanadium structure. Behind the blanket, there is a neutron reflector which consists of calcium oxide $(\mathrm{CaO})$, lithium coolant and vanadium structure.

\section{II.A.4 Reference SiC/Li $\mathrm{ZrO}_{3} / \mathrm{He}$ Blanket Design (R4)}

The AIRIES project developed a design AIRIES-I $I^{5}$ using silicon carbide ( $\mathrm{SiC})$ structure and helium $(\mathrm{He})$ coolant. The breeding material is solid lithium zirconate $\left(\mathrm{Li}_{2} \mathrm{ZrO}_{3}\right)$, with isotopically tailored $\mathrm{Zr}$ to reduce off-site exposure during an accident. This design incorporates a Be neutron multiplier.

\section{II.A.5. Blanket Design Variants (V1-V4)}

In order to obtain a more direct comparison of different possible structural materials, variants of the $\mathrm{FeS} / \mathrm{Li}_{2} \mathrm{O} / \mathrm{H}_{2} \mathrm{O}$ blanket design $\mathrm{R} 1$ described in section III.A.1 with other structural materials were considered. The materials studied were stainless steel 316 (316SS), the manganese steel alloy VA64, the proposed improved stainless steel known as PCA, and the vanadium alloy V$4 \mathrm{Cr}-4 \mathrm{Ti}$.

\section{II.B. Divertor, Shield And Vacuum Vessel Designs}

The walls of the divertor chamber were of the same design and materials as the first-wall. A dispersion-strengthened copper (DSCU) divertor plate of the type being developed for ITER 6 was used in all designs.

The shield design was $62 \%$ structure, $38 \% \mathrm{H}_{2} \mathrm{O}$ followed by a $4 \mathrm{~cm} \mathrm{~Pb}$ gamma shield. The same structural material used in the blanket was used in the shield and in the vacuum vessel, except for the vanadium alloy $(\mathrm{R} 3, \mathrm{~V} 1)$ and the silicon carbide (R4) designs, for which ferritic steel was used in the shield and vacuum vessel. 


\section{II.C. Procedures for Determining Demo Design Characteristics}

A $1500 \mathrm{MW}, 10$ effective full power year (EFPY) DEMO design was developed based on each of the four reference and four variant blanket designs described in section II.A. Each design was constrained to satisfy a common set of physics and engineering constraints, evaluated using the materials property data appropriate to the respective designs. The calculation iterated to determine the minimum major radius device that would satisfy the constraints. The calculational model ${ }^{7}$ is summarized below.

The structural components of the central solenoid, toroidal field coil and support structure were sized to satisfy ASME code requirements for SS316LN, taking into account reduction of the stress allowable $S_{m}$ due to crack growth for cyclic operation. Adequate conductor cross section was allowed to accommodate the ITER-EDA Outline Design current density ${ }^{8}$ and a maximum toroidal field of $B=12 \mathrm{~T}$. The number of pulses used for the stress allowable reduction is determined from the total operating time and the $10^{4} \mathrm{~s}$ pulse length, plus $10^{4}$ shakedown pulses.

The flux core was sized to provide the volt-seconds required to induce and maintain the plasma current during the burn pulse, taking into account bootstrap and non-inductive ${ }^{10}$ current drive, and allowing for $50 \%$ reduction in startup resistive volt-seconds due to startup assist. An upper limit of $80 \%$ bootstrap current was imposed to take into account the necessity to provide some non-inductive current drive to tailor current profiles. The pulse length of $10^{4} \mathrm{~s}$ was determined to minimize major radius from a tradeoff between the increasing flux core needed for longer pulses and the increasing magnet structure needed for a larger number of pulses.

The shield was sized to limit peak nuclear heating and neutron fluence in the inboard TF coil to $1 \mathrm{~mW} / \mathrm{cm}^{3}$ and $2 \times 10^{22} \mathrm{n} / \mathrm{m}^{2}$, respectively ${ }^{11}$. The blanket was sized to attenuate $95 \%$ of the nuclear energy flux and to achieve a (1D model) tritium breeding ratio $\geq 1.20$ in order to insure tritium self-sufficiency.

The vacuum vessel, located between the blanket and the shield, was sized to withstand an overpressure of 10 atmospheres. The vacuum vessel and shield were designed to last for the entire 10 EFPY of operation.

The first wall heat removal element and strongback were sized to satisfy the ASME code stress allowable under coolant and disruption pressures. The plasma minor radius must be large enough to satisfy the $q_{95}$ constraint and also to result in a first wall peak heat flux below the ASME code thermal stresslimited value. A tube bank model that has been adjusted to match more exact models and a peaking factor of 2.0 were used for the heat flux calculations.

The major radius was then determined by summing the constituent thicknesses and adding $10 \mathrm{~cm}$ to allow for gaps between the first wall and toroidal field coil. 
The average plasma temperature was set at $\mathrm{T}=10 \mathrm{keV}$ and the plasma density was determined from the specified fusion power. In order that each design point would have the same confinement potential, the plasma current was then calculated, using the ITER89P scaling law' with the appropriate confinement enhancement factor, $\mathrm{H} \leq 3$, to yield an energy confinement time $\tau=$ 3.0 s, which provides some margin for power balance. The solution is constrained to satisfy $\beta_{\mathrm{N}} \leq 4$. A $10 \%$ He concentration plus an oxygen impurity $Z_{\text {eff }}=1.5$ were assumed. The ITER form of the physics constraints' and the general ITER design procedures ${ }^{11}$ have been followed.

\section{II.D. DEMO Design Characteristics}

The composition and dimensions of the components which are activated in the eight DEMO designs are given in Tables 1 and 2 . The corresponding major design parameters are given in Table 3. The DEMO designs differed because of differences in the thermo-mechanical properties of the materials, which are given in appendix $A$. The major radii varied from $6.2 \mathrm{~m}$ to $7.4 \mathrm{~m}$. The lower first-wall heat flux limit of austenitic stainless steels (316,PCA) in V2 and V3 and the reflectors in R3 and R4 account for the larger sizes of these designs. These large differences in size have an impact on the waste streams.

\section{WASTE DISPOSAL EVALUATION}

\section{III.A. Waste Disposal Indices}

While there are no accepted national or international criteria for the disposal of fusion wastes, the criteria presently used for other forms of radioactive waste provide some perspective for fusion radioactive waste disposal. Several international criteria ${ }^{12}$ for LLW are collected in Table 4. There are several parameters which will play a major role in fusion radioactive waste handling and disposal: waste disposal rating, and the associated deep disposal index, specific activity, total activity, contact dose and life cycle volume.

The waste disposal rating (WDR) is defined in terms of the maximum allowable dose that could be received by an inadvertent intruder to an abandoned waste site. Fetter ${ }^{13}$, based on the Nuclear Regulatory Commission (NRC) intruder dose scenario", calculated the Specific Activity Limits (SAL) of each isotope which would result in a $500 \mathrm{mrem} / \mathrm{yr}$ whole body dose or 1500 $\mathrm{mrem} / \mathrm{yr}$ dose to a single organ to an inadvertent intruder. In the inadvertent intruder scenario, construction of a house on the waste disposal site after the assumed 100 year period of institutional control is assumed. Construction workers are exposed to gamma radiation from the waste and inhale suspended waste particles. If the waste is still stabilized, they recognize it as radioactive waste and construction stops after 6 hours. Class $C$ waste ${ }^{14}$, which is the most 
radioactive class of waste still considered low-level, is assumed to be stabilized for 500 years. If the waste is no longer stabilized, the house is completed, with construction taking 500 hours. The house is then occupied, and the residents of the house are exposed to direct gamma radiation and suspended waste particles and grow half of their food on the waste site. From this type of analysis the Specific Activity Limits (SAL) for the various radioisotopes can be established and the corresponding critical concentrations can then be calculated. The WDR is defined as the ratio of the actual concentration to the critical concentration for each radioisotope summed over all radioisotopes present. Thus, satisfaction of the dose limits to an inadvertent intruder corresponds to WDR 1 .

The SALs for the radioisotopes were taken from the lower limit of values given in Fetter ${ }^{13}$ and are included in appendix $B$. These values were calculated for activated metals. The results would be lower for wastes which are not activated metals because of lower stability of these wastes. The values in appendix $B$ were used as the near-surface burial limits The actual specific activities of the different components in each design were calculated by REAC $3^{15}$ as discussed in the next section. Using the ratio of the actual specific activity to the SAL for each radioisotope and summing over isotopes then yielded the waste disposal rating (WDR) for each component.

The deep disposal index (DDI) is a parameter which gives some sense of the relative hazard of the high level waste. The deep disposal index is calculated by summing the life cycle volume multiplied by the WDR for all components with a WDR greater than 1.0.

The specific or total activity of the waste gives only a general representation of the waste hazard, but these values are often quoted. In some countries, these parameters may form the basis for waste classification (Table 4).

When handling radioactive material, one of the most important parameters is the contact dose. This determines the amount of shielding required, if remote handling is required, if the material can be recycled, etc. Therefore, this is a strong factor in determining the cost of handling and transporting the waste. The contact dose is defined as the photon dose at the surface of an uniformly contaminated semi-infinite slab of the material. Contact dose is also a basis for waste classification in some countries (Table 4).

All parameters are calculated based on several assumptions. Solid breeding materials are not recycled. All liquid materials are removed and handled separately. Water is treated and released to the environment. Lithium and lithium lead are used for the life of the plant and the quantity used is twice the volume present in the reactor. Liquids are then disposed of separately as radioactive waste. All components are disposed of as units. No credit is taken for dilution. The entire blanket region inside the vacuum vessel is removed at each blanket replacement. Since tritium $\left(t_{1 / 2}=12.5\right.$ years $)$ is not important on the long time scales of concern for waste disposal, it is not considered. 


\section{III.B. Evaluation of Waste Disposal Indices}

Four separate codes were used in evaluating the waste disposal indices. These codes performed the neutronics calculations, life cycle volume calculations, the activation calculations, and the dose calculations.

The ONEDANT one dimensional, discrete ordinates transport code ${ }^{16}$ with $\mathrm{S}_{8}$ angular quadrature was used. The cross section library used was MATXS10 $0^{17,8}$, which was developed specifically for high-energy neutron transport calculations. The cross section set is a $\mathrm{P}_{4}$ scattering set and consists of 30 neutron groups and 12 photon groups.

The neutron activation analysis was performed using the REAC 3 code ${ }^{15}$. This code and its associated activation cross sections were developed specifically for high energy neutron activation analysis in the fusion environment. It includes an extensive 175 energy group activation cross section library. The 30 group neutron flux from ONEDANT was contant-in-lethargy interpolated to form the 175 group flux. This code was then used to calculate the radioactive inventories for specified times and operational scenarios.

The Microshield code ${ }^{19}$ was used to perform the contact dose rate calculations. The REAC*3 code outputs the decay photon emission rate by energy group and the Microshield code was used to determine a semi-infinite slab contact dose rate response function for each of the decay photon energy groups and material. The response function was then folded with the REAC*3 output to determine the contact dose.

The flux was calculated at a number of mesh points through the reactor based on a one dimensional cylindrical model centered on the plasma centerline. All parameters were then calculated at each mesh point, and the results for each component were the volume-weighted average of all solid materials in that component. The liquid materials were treated separately.

The component volumes were calculated with a simple geometric model. The neutronics code was then used to calculate component failure and replacement rates due to radiation damage. Life cycle component volumes were then determined from component volumes and replacements over lifetime.

\section{III.C. Comparison of Waste Disposal Rating for DEMO Designs}

The waste disposal rating (WDR), which is based on detailed analysis of the dose that could be received by an inadvertent intruder, is believed to be representative of a realistic criterion for fusion waste disposal. The WDR limit for near-surface burial is unity. The results for the first wall, divertor wall, blanket, vacuum vessel and shield of each DEMO design are shown in Figures 15 , respectively. Figures 1 and 2 show that for either design $\mathrm{R} 3(\mathrm{~V} / \mathrm{Li})$ or design $\mathrm{V} 1\left(\mathrm{~V} / \mathrm{Li}_{2} \mathrm{O} / \mathrm{H}_{2} \mathrm{O}\right)$, the vanadium alloy first wall and divertor wall will meet this near-surface burial criterion (WDRs 1 ) if impurities can be controlled to within plausible bounds. The ferritic steel design R1 will be below the WDRs 1 limit 
without impurities, but with the specified impurities ferritic steel slightly exceeded this limit in the divertor wall. (See Appendix A for a discussion of assumed impurities.) The silicon carbide in the first wall and divertor wall was just above WDR $\leq 1$ limit. For all other structural materials, WDR $>>1$ in the first wall and divertor wall.

The WDR for the different blankets is shown in Figure 3. In the designs (R1,R3,R4,V1) incorporating blankets with the lower activation structural materials ( $\mathrm{V}, \mathrm{SiC}$, and $\mathrm{FeS}), \mathrm{WDR} \ll<1$. However, in the SiC design the zirconium in the $\mathrm{Li}_{2} \mathrm{ZrO}_{3}$ breeder must be (expensively) isotopically tailored in order to meet the WDRs1 criterion.

The WDR of the MS $/ \mathrm{Li}_{17} \mathrm{~PB}_{83} / \mathrm{H}_{2} \mathrm{O}$ blanket design (R2) is noticeably higher than the other blankets. The WDR for each component is the volume weighted average of all solid materials within that component. In the blanket of design $\mathrm{R} 2$, the only solid material is the MANET structure, therefore, the WDR is solely due to the high activation MANET. In designs V2-V4, which incorporate the high activation austenitic steels, the WDR of the blanket is the volume weighted average of these high activation structural materials and the low activation breeder $\left(\mathrm{Li}_{2} \mathrm{O}\right)$ and neutron multiplier $(\mathrm{Be})$.

All lithium-bearing materials, without impurities, had WDR's much less than unity. Activation of elemental lithium does not pose any long-term disposal problems and the WDR is determined by alloying elements and impurities. With impurities included, the lithium lead was the only breeder which did not meet near-surface burial limits.

The divertor plates for the different designs all used the same material, dispersion strengthened copper. The WDR without impurities tended to be slightly greater than unity, and with impurities it was considerably greater.

The use of ferritic steel in the vacuum vessel and shield led to designs (R1,R3,R4,V1) for which these components satisfy WDR $<<1$. The use of austenitic, martensitic and manganese steels in these components produced WDR $\gg 1$ for these components. We understand that low-activation versions of the martensitic steel (MANET) and the manganese steel (VA64) have been considered and perhaps are under development.

A detailed comparison of the elemental contributions to the WDR for each component in each design is given in appendix $C$.

\section{III.D. Comparison of Deep Disposal Index for DEMO Designs}

Many of the components do not meet the near-surface burial limits, WDR $\leq 1$,particularly with the levels of impurities considered. Figure 6 shows the deep disposal index (DDI), which is a rough measure of the hazard posed by the high-level waste, WDR $>1$, from each design. The designs which incorporated the lower activation structural materials (i.e. $\mathrm{V}, \mathrm{FeS}, \mathrm{SiC}$ ) had approximately 3 orders of magnitude lower DDI's than the other designs. A large component of 
the DDI in the former was due to the dispersion-strengthened copper divertor plate.

For the $\mathrm{V} / \mathrm{Li}$ reference design ( $\mathrm{R} 3$ ) and the $\mathrm{V} / \mathrm{Li}_{2} \mathrm{O} / \mathrm{H}_{2} \mathrm{O}$ variant design (V1), the only component that did not meet WDRs1 criterion and which therefore contributes to the DDI was the divertor plate. In the $\mathrm{SiC} / \mathrm{Li}_{2} \mathrm{ZrO}_{3} / \mathrm{He}$ reference design (R4), the first wall and divertor wall WDR were slightly greater than 1.0 and therefore in addition to the divertor plate also contributed to the DDI for this design. In the $\mathrm{FeS} / \mathrm{Li}_{2} \mathrm{O} / \mathrm{H}_{2} \mathrm{O}$ reference design, the divertor wall WDR was slightly greater than 1.0 and therefore also contributed to the DDI. These three designs, because of the low WDR values and resulting low DDI's, pose less of an overall long term disposal hazard than the other designs.

In all other designs (i.e. R2,V2,V3,V4), all components had WDR $>1$ and therefore contributed to the DDI. The first wall and divertor wall in most cases accounted for the bulk of the DDI because their WDR was much higher than the WDR of the remainder of the components.

\section{III.E. Comparison of Specific Activity for DEMO Designs}

For all first wall materials, the specific activiy was nearly the same at shutdown $\left(-10^{8} \mathrm{Ci} / \mathrm{m}^{3}\right)$. There was a very significant difference in the rate of decay for the specific activity in the different first wall materials. The specific activity at 10 years after shutdown for the different first walls is shown in Figure 7.

Both vanadium and silicon carbide have specific activities which have decayed by orders of magnitude at 10 years after shutdown. The impurities in silicon carbide dominated the specific activity at 10 years after shutdown and increased the specific activity by two orders of magnitude. Compared with silicon carbide with the impurities removed, the vanadium alloy has a higher specific activity at 10 years after shutdown. The silicon carbide design (R4) with impurities removed comes close to meeting the Japanese $<1 \mathrm{Ci} / \mathrm{m}^{3}$ criterion for low level waste. No other design comes close to meeting this criterion.

The common divertor plate material still has a very high specific activity $\left(-2 \times 10^{8} \mathrm{Ci} / \mathrm{m}^{3}\right)$ at 10 years after shutdown in all of the designs.

\section{III.F. Comparison of Contact Dose for DEMO Designs}

For all first wall materials, the contact dose was nearly the same at shutdown $\left(-10^{9} \mathrm{mSv} / \mathrm{hr}\right)$. There was a very significant difference in the rate of decay for the contact dose in the different first wall materials. The contact dose at 10 years after shutdown for the different first walls is shown in Figure 8.

The contact dose of both vanadium and silicon carbide have decayed by orders of magnitude at 10 years after shutdown. The impurities in silicon carbide dominated the contact dose at 10 years after shutdown and increased the contact dose by several orders of magnitude. The rapid decay of the contact dose 
in these materials will greatly reduce handling requirements, assuming that the impurities can be controlled. The vanadium alloy had a much lower contact dose at 10 years after shutdown than the silicon carbide, even with the impurities removed from the latter. In this regard, vanadium is much better than any of the other materials. The vanadium designs (V3,R1) come close to meeting the IAEA $<2 \mathrm{mSv} / \mathrm{hr}$ criterion for low level waste at 10 years after shutdown.

The common divertor plate material still has a very high contact dose $\left(-2 \times 10^{7} \mathrm{mSv} / \mathrm{hr}\right)$ at 10 years after shutdown in the various designs. This is primarily due to the reaction ${ }^{63} \mathrm{Cu}(n, \alpha)^{60} \mathrm{Co}$. The 5.27 year half-life of Cobalt-60 will require a longer decay time to reduce the contact dose to the same levels that vanadium and silicon carbide reached at 10 years after shutdown.

\section{III.G. Life Cycle Waste Volume}

A comparison of the life cycle waste volume (LCV) for each design is shown in Figure 9. The difference between the smallest and largest LCV was slightly more than a factor of two.

In the variant designs using $316 \mathrm{SS}$ (V2) and PCA (V3), the shield volume was much larger than in the other designs. A greater radial shielding thickness was not needed for these designs, but as a result of the relatively poor heat removal properties of the stainless steels, the first wall heat load must be reduced relative to the other designs to meet thermal stress limits. This results in a larger plasma chamber, which increases the volume of all materials which surround the plasma chamber. The shield was most noticeably affected because it was at the largest major radius.

The Argonne design" and the AIRIES-I design both incorporate large neutron reflectors inside the vacuum vessel. In this analysis, the entire blanket/reflector region inside the vacuum vessel was replaced when the structure at the front of the blanket had reached its radiation damage limit. This caused the large blanket/reflector regions in the $\mathrm{V} / \mathrm{Li}$ and $\mathrm{SiC} / \mathrm{Li}_{2} \mathrm{ZrO}_{3} / \mathrm{He}$ reference designs to be replaced once each. Mori et al. ${ }^{2}$, which was the basic reference for the $\mathrm{FeS} / \mathrm{Li}_{2} \mathrm{O} / \mathrm{H}_{2} \mathrm{O}$ reference design, incorporated a replaceable and a permanent blanket in their design. This was not done for any of the blankets in this analysis, but this clearly is a method to reduce the waste volume generated in the blanket.

\section{SUMMARY AND CONCLUSIONS}

The waste disposal characteristics of candidate DEMO reactors were evaluated. DEMO designs were developed, based on blanket designs from the literature using advanced and existing structural materials and based on 
advanced tokamak physics. Neutron activation calculations were made for the different designs, and three international low-level waste disposal criteria were evaluated. In general, the more involved USNRC-type criterion ${ }^{14}$, based on pathway analysis of the dose to an inadvertent intruder and leading to a waste disposal rating (WDRs 1) criterion, was less demanding than the simple criteria based on specific activity or contact dose. We believe the WDR type criterion to be more realistic and base our conclusions primarily on it.

Our analysis indicates that it should be possible to develop fusion reactor designs which satisfy the WDRs1 criterion and thus qualify as low-level waste that can be buried in near-surface repositories. The vanadium alloy $\mathrm{V}-4 \mathrm{Ti}-4 \mathrm{Cr}$ has a very low WDR in its pure form; it can tolerate significant impurity concentrations up to $3.8 \mathrm{ppm} \mathrm{Nb}, 15 \% \mathrm{Si}$, or $71 \mathrm{ppm} \mathrm{Mo}$, or some prorated combination thereof, and still satisfy WDR $\leq 1$. The low activation ferritic steel in pure form has WDR $\cong 0.5$; it can tolerate a tungsten alloying up to $3.7 \mathrm{w} / \mathrm{o}$ or impurity concentrations up to $1.3 \mathrm{ppm} \mathrm{Nb}$ or $18 \mathrm{ppm} \mathrm{Mo} \mathrm{or} 0.025 \mathrm{w} / \mathrm{o} \mathrm{Al}$, or some prorated combination thereof, and still satisfy WDRs 1 . These numbers are for the most limiting first-wall and divertor chamber wall components; higher impurity concentrations could be tolerated in other components. For pure silicon carbide, $1<$ WDR $<3$ in the first-wall and divertor chamber wall. Thus, taking into account the uncertainties involved in the WDR evaluation, $\mathrm{V}-4 \mathrm{Ti}-4 \mathrm{Cr}$, low activation ferritic steel and silicon carbide, in that order, would seem to have a good possibility of leading to fusion reactors that could qualify for LLW nearsurface burial, provided that impurities (particularly $\mathrm{Mo}, \mathrm{Nb}, \mathrm{Ag}, \mathrm{Al}$ ) can be controlled within plausible limits.

The other structural material that is being considered for DEMO, MANET, is not close to meeting the WDRs1 criterion; however, we understand that a low activation MANET is under development in Europe, and this possibly could provide a fourth structural option for LLW qualification. The austenitic stainless steels (316, PCA) have been shown to be unsuitable for LLW qualification numerous times, and we included them only for comparison. The manganese substituted austenitic steel, VA64, also is not close to meeting the WDR criterion; however, a low-activation version that is under consideration in Europe was found to have WDR $\cong 0.7$ in pure form, and may possibly represent a fifth structural option for a fusion reactor that would qualify as LLW for nearsurface burial.

In the blankets, the pure $\mathrm{V}-4 \mathrm{Ti}-4 \mathrm{Cr}$, ferritic steel and $\mathrm{SiC}$ structures satisfied WDR $<<1$, leaving a large margin for impurities. All four lithiumbearing tritium breeding materials considered $\left(\mathrm{Li}_{2} \mathrm{O}, \mathrm{Li}_{2} \mathrm{ZrO}_{3}, \mathrm{Li}, \mathrm{Li}_{17} \mathrm{~Pb}_{83}\right)$ met the WDR $\leq 1$ criterion in pure form, although it was necessary to isotopically tailor the $\mathrm{Zr}$ to do so. The $10 \mathrm{ppm} \mathrm{Ag}$ impurity assumed in the $\mathrm{Li}_{17} \mathrm{~Pb}_{83}$ in the analysis increased the WDR to near 4, indicating the need to limit Ag to $\leq 2.5 \mathrm{ppm}$. The $\mathrm{Al}_{2} \mathrm{O}_{3}$ insulator suggested as a possibility in one of the designs led to an overall blanket WDR $\cong 4$ and is definitely a poor choice in this respect. 
The dispersion strengthened copper divertor plate of the type being developed for ITER did not meet the WDRs 1 criterion because of the $\mathrm{Al}$ in the $\mathrm{Al}_{2} \mathrm{O}_{3}$ dispersion material. A maximum $\mathrm{Al}$ concentration of $0.11 \mathrm{w} / \mathrm{o}$ in the dispersion strengthened copper can be tolerated. It seems feasible that divertor plate designs could be developed using low-activation structural materials.

Although we believe the WDR criterion is the most realistic, we considered other LLW criteria as well. All materials have roughly the same specific activity $\left(-10^{8} \mathrm{Ci} / \mathrm{m}^{3}\right)$ at shutdown, but the $\mathrm{SiC}$ and $\mathrm{V}-4 \mathrm{Ti}-4 \mathrm{Cr}$ activities decay much more rapidly than the others, and these materials satisfy the very demanding Japaneses $1 \mathrm{Ci} / \mathrm{m}^{3}$ LLW criterion after about 100 years. All materials also have about the same contact dose $\left(-10^{9} \mathrm{mSv} / \mathrm{hr}\right)$ at shutdown. The V-4Ti$4 \mathrm{Cr}$ components satisfied the very stringent IAEA $\leq 2 \mathrm{mSv} / \mathrm{hr} \mathrm{LLW}$ criterion within 10 years after shutdown, but none of the other structural materials satisfied this criterion.

\section{APPENDIX A. MATERIALS PROPERTIES}

This appendix describes all material compositions and thermo-mechanical and radiation damage properties that were used in this work. It also gives brief discussions of why some choices were made. Thermo-mechanical properties are given in Table A.1 and compositions in Tables A.2-A.4. Operating temperatures for the structural materials are taken from the blanket design studies ${ }^{2.5}$ and given in Table A.1. Impurities must be controlled to reduce activation. For this reason a representative level of unintentional impurities is included for each material.

\section{A.1. Structural Materials}

\section{A.1.a. Reduced Activation Ferritic Steel}

Ferritic steels are considered as possible low activation materials and are being actively developed in the US, Japan, and Europe. The reference structural material in the Japanese $\mathrm{FeS} / \mathrm{Li}_{2} \mathrm{O} / \mathrm{H}_{2} \mathrm{O}$ blanket design ${ }^{2}$ is of this type. The thermo-mechanical properties were taken from the Nuclear Systems Materials Handbook ${ }^{20}$ for the material HT-9m. According to Klueh ${ }^{21}$, good agreement in materials properties exists between this material and the reduced activation steels. Gelles ${ }^{22}$ reports that ferritic steels are radiation resistant to 200 displacements per atom (dpa). The low-activation ferritic steel composition, including impurities, was taken from Bloom ${ }^{23}$.

\section{A.1.b. MANET}

Martensite for NET (MANET) is the reference material in the design of the European lithium-lead blanket design ${ }^{3}$. All properties and the composition were taken from the NET database ${ }^{24}$. In the absence of data, a radiation damage 
lifetime of $200 \mathrm{dpa}$ was chosen so as not to bias the comparison with the reduced activation ferritic steel and vanadium.

\section{A.1.b. $V-4 C r-4 T i$}

This material is currently under development in the US as a lowactivation structural material. The properties for this material were gathered through personal communications $\mathrm{s}^{25}$. A damage lifetime of $200 \mathrm{dpa}$ is used ${ }^{25}$. An impurity level of $1 \mathrm{ppm} \mathrm{Nb}$ was assumed ${ }^{25}$.

\section{A.1.d. Silicon Carbide}

The properties of silicon carbide were taken from the AIRIES-I report ${ }^{5}$. In this report, a radiation lifetime of $200 \mathrm{dpa}$ was used, and this same value was used in the present work. Impurity concentrations were given in the AIRIES-I report. Fetter ${ }^{26}$ gave a different set of impurities. Both are included in Table A.2, but the impurity levels given in the AIRIES-I report are used in the analysis.

\section{A.1.e. 316 Stainless Steel}

This material has been used extensively in industry and a large database of its properties exists. This material exhibits high swelling rates at high temperatures and is therefore limited to operation below $400 \mathrm{C}$. The mechanical properties and composition were taken from the ITER-CDA materials database ${ }^{27}$. Radiation damage will limit operation, with an expected lifetime of about 60 $\mathrm{dpa}^{25}$.

\section{A.1.f. $P C A$}

This material is a modified stainless steel to improve radiation damage resistance. The 316SS thermo-mechanical properties were assumed. The composition was taken from Kinzig ${ }^{28}$. In the absence of data and since PCA is designed specifically to improve radiation damage resistance, an irradiation lifetime of $100 \mathrm{dpa}$ was assumed to show the effect of increased lifetime.

\section{A.1.g. VA64}

VA64 is a manganese stabilized austenitic stainless steel which is an alternative to 316 stainless steel. Zucchetti and Zublena ${ }^{29}$ and Piatti and Schiller ${ }^{30}$ studied the properties of several manganese steels. Piatti and Schiller found that VA64 had a "noticeably high thermal stress resistance" and this was the reason for selecting VA64. Piatti and Schiller found that swelling behavior of high manganese austenitic steels are similar to type 316SS. Thus, the same value of 60 $\mathrm{dpa}$, as for 316SS, was used for the radiation damage lifetime. The stress limit was taken from Piatti and Schiller and all other properties were taken from Zucchetti and Zublena. 


\section{A.1.h. Divertor Material - Dispersion Strengthened Copper}

The divertor will be subject to extreme high heat loads and one of the leading candidate materials is the dispersion strengthened copper, which is being developed for the ITER divertor ${ }^{6}$. Copper has very high thermal conductivity, and by dispersion strengthening with alumina $\left(\mathrm{Al}_{2} \mathrm{O}_{3}\right)$ it is expected to be able to withstand intense thermal loading. The properties were taken from the ITER-CDA materials database ${ }^{16}$. The radiation damage lifetime of 150 dpa was chosen based on the report by Zinkle and Fabritsiev ${ }^{33}$; they found that swelling was still minimal at values up to $150 \mathrm{dpa}$. An operation temperature of $500 \mathrm{C}$ was chosen based on Zinkle and Fabritsiev, in which they found that "based on the available data, dispersion strengthened copper ( $\mathrm{Cu}$ $\mathrm{Al}_{2} \mathrm{O}_{3}$ ) may be used up to temperatures in excess of $500 \mathrm{C}^{\prime \prime}$. The impurity concentrations for copper were taken from Holdren ${ }^{32}$.

\section{A.2. Breeding Materials}

Each of the reference designs used a different breeding material to produce the required tritium. The compositions are given in Table A.3.

\section{A.2.a. Lithium Oxide}

The Japanese reference blanket design ${ }^{2}$ uses solid $\mathrm{Li}_{2} \mathrm{O}$ for tritium breeding. The solid breeder is in pebble form at $85 \%$ theoretical density and a $70 \%$ packing factor. Impurity concentrations were taken from Holdren ${ }^{32}$.

\section{A.2.b. Lithium Lead}

The European reference blanket design ${ }^{3}$ uses the liquid eutectic $\mathrm{Li}_{17} \mathrm{~Pb}_{83}$. The lithium is enriched to $90 \% \mathrm{Li}-6^{3}$. Impurity concentrations were given by Holdren $^{32}$ and by Fetter ${ }^{26}$. There is a large discrepancy between them. Both are given in Table A.3. The impurity concentrations from Holdren were used in this analysis since this is the more recent work and Fetter was cited in the Holdren paper.

\section{A.2.c. Lithium}

The Argonne reference blanket design ${ }^{4}$ uses pure lithium in liquid metal form as both the breeder and coolant. The lithium is not enriched. The impurity concentrations were taken from Fetter ${ }^{26}$.

\section{A.2.d. Lithium Zirconate}

The AIRIES-I reference blanket design ${ }^{5}$ uses solid $\mathrm{Li}_{2} \mathrm{ZrO}_{3}$ for tritium breeding. The solid breeder is in pebble form at $90 \%$ theoretical density with an $80 \%$ packing factor. To reduce activation, the zirconium is isotopically tailored. The tailored composition is $99.908 \% \mathrm{Zr}-\mathbf{9 2} ; 0.057 \% \mathrm{Zr}-90 ; 0.013 \% \mathrm{Zr}-91 ; 0.019 \%$ $\mathrm{Zr}-94 ; 0.003 \% \mathrm{Zr}-96$. The Li-6 was enriched to $80 \%$. The impurity concentrations were also taken from the AIRIES-I report ${ }^{5}$. 


\section{A.3. Other Materials}

\section{A.3.a Neutron Multiplier}

In the Japanese reference ${ }^{2}$ design and the AIRIES-I reference ${ }^{5}$, beryllium

(Be) was added as a neutron multiplier to increase tritium breeding ratio (TBR). In the Japanese design, the beryllium is present in solid blocks. In the AIRIES-I design, it is present in pebble form at $90 \%$ theoretical density and an $80 \%$ packing factor. The impurity concentrations were taken from Fetter ${ }^{26}$.

\section{APPENDIX B. SPECIFIC ACTIVITY LIMITS}

Specific Activity Limits for Class $\mathrm{C}$ disposal ${ }^{14}$ as calculated by Fetter ${ }^{13}$, are given in Table B.1.

\section{APPENDIX C. ELEMENTAL CONTRIBUTIONS TO THE WASTE DISPOSAL RATING}

The contributions to the Waste Disposal Rating (WDR) for the most significant elements present are given in Table C. 1 for each component of each design.

\section{APPENDIX D. DETAILED DISCUSSION OF WASTE DISPOSAL CHARACTERISTICS OF CANDIDATE TOKAMAK DEMO DESIGNS}

\section{D.1. DEMO with Reference $\mathrm{FeS} / \mathrm{Li}_{2} \mathrm{O} / \mathrm{H}_{2} \mathrm{O}$ Blanket Design (R1)}

The structural material in all components, except for the divertor plate, was ferritic steel (FeS). The structure of the divertor plate was dispersion strengthened copper. In Figures D.1-D.3, "other" refers to alumina $\left(\mathrm{Al}_{2} \mathrm{O}_{3}\right)$, lithium oxide $\left(\mathrm{Li}_{2} \mathrm{O}\right)$, and beryllium $(\mathrm{Be})$ in the blanket and lead $(\mathrm{Pb})$ in the shield.

The waste disposal rating for the various components are shown in Figure D.1. The first wall, vacuum vessel, and shield will meet the WDR limit of unity. The ferritic steel in the divertor wall will slightly exceed this limit with the specified impurities, but the pure ferritic steel in the divertor wall has a WDR of 0.55 , which shows that it could meet the WDR criterion if impurities are better controlled.

Tungsten $(W)$ was the primary element of concern in the pure ferritic steel structure, and the impurities $\mathrm{Mo}, \mathrm{Nb}$, and $\mathrm{Al}$ contribute significantly to the WDR of ferritic steel. In the divertor wall, the elemental contributions to the WDR was $\mathrm{W}, 0.54 ; \mathrm{Mo}, 0.10 ; \mathrm{Nb}, 0.18$; and $\mathrm{Al}, 0.37$. We define the Maximum Impurity 
Concentration (MIC) as the concentration of an impurity which would increase the WDR of the pure structure to unity. The MICs of $\mathrm{Mo}, \mathrm{Nb}$ and $\mathrm{Al}$ in the firstwall spectrum are $31 \mathrm{ppm}, 2.3 \mathrm{ppm}$, and $0.048 \%$, respectively. The MICs for $\mathrm{Mo}, \mathrm{Nb}$ and $\mathrm{Al}$ in the divertor-wall spectrum are $18 \mathrm{ppm}, 1.3 \mathrm{ppm}$, and $0.025 \%$, respectively. The low-activation ferritic steel in pure form could tolerate a $\mathrm{W}$ alloy concentration up to $5.2 \%$ in the first-wall and $3.7 \%$ in the divertor-wall.

In the divertor plate, the copper contributes very little to the WDR. The aluminum present in the dispersion strengthener, alumina $\left(\mathrm{Al}_{2} \mathrm{O}_{3}\right)$, was responsible for nearly all of the pure structure WDR. The concentration of aluminum is $0.2 \%$. Fetter's results ${ }^{13}$ lead to an estimated limit of $0.1 \% \mathrm{Al}$ for that particular design. If near-surface burial limits are to be met, it may be necessary to reduce the alumina content. Pure $\mathrm{Cu}$ has a WDR of 0.4. The maximum allowable concentration of $\mathrm{Al}$ in dispersion strengthened copper is $0.11 \%$. The impurities in the divertor plate greatly increased the WDR of the divertor plate and in particular the silver $(\mathrm{Ag})$ contributed 5.92 to the WDR. The $\mathrm{MIC}$ for $\mathrm{Ag}$ is $1.2 \mathrm{ppm}$ in pure copper (WDR=0.4).

In the Japanese blanket design, a thermal insulator material would be required to increase minimum temperatures ${ }^{2}$. The material that was mentioned ${ }^{2}$ was alumina $\left(\mathrm{Al}_{2} \mathrm{O}_{3}\right)$. Irradiation of aluminum produces the isotope $\mathrm{Al}-26$, which is a limiting isotope for waste disposal. Even though only a small quantity of alumina would be present in the design, it would be sufficient to prevent near-surface burial of the entire blanket. In the absence of this alumina, the blanket would meet the near-surface burial criterion, WDR s1.0. Since there are many other possible thermal insulator materials, it should be reasonable to assume that an acceptable replacement could be found. Therefore, alumina is only considered in this appendix and not included in any of the data or figures in the body of the paper. In Figure D.1, the contribution to the blanket WDR by other materials is alumina, $\mathrm{WDR}=3.54$; beryllium, $\mathrm{WDR}=0.06$; and lithium oxide, WDR $=0.07$. The beryllium and lithium oxide used in this design will easily meet the criterion WDR $\leq 1.0$.

In Figure D.1, the WDR's of the first wall and divertor wall showed a large difference despite being the same material and design. This resulted from differences in geometry. The divertor wall is further from the plasma and therefore subject to a lower flux because of the geometric attenuation. The lifetime is limited by the peak flux and the irradiation parameters were evaluated at the average flux. Since the divertor wall is further from the plasma, the peak flux, which determines the irradiation lifetime, is lower and therefore the irradiation time longer. Also, because of geometry, the peak to average ratio for the neutron load on the first wall was greater than for the divertor wall. Since activation calculations are performed with the average flux, the divertor wall receives a larger average fluence than the first wall over their respective lifetimes. This resulted in an average neutron load of $9.5 \mathrm{MW}-\mathrm{yr} / \mathrm{m}^{2}$ for the first wall and $13.7 \mathrm{MW}-\mathrm{yr} / \mathrm{m}^{2}$ for the divertor wall. 
Figure D. 2 shows the specific activity for the various components. The specific activity for each component is given at shutdown and 1,10,102,103, and $10^{4}$ years after shutdown. By comparison, the Japanese low-level waste (LLW) limit ${ }^{12}$ for solid wastes is $1 \mathrm{Ci} / \mathrm{m}^{3}$. Using this criterion, none of the components would be classified as LLW until at least 100 years after shutdown. Impurities do not contribute significantly to the waste activity until 100 years after shutdown.

The contact dose for each component at various times after shutdown is shown in Figure D.3. The IAEA proposal for a LLW limit for solid waste is $<2$ $\mathrm{mSv} / \mathrm{hr}^{12}$. Based on this criterion, the first wall, divertor wall, and divertor plate would not meet this limit within 100 years after shutdown. The vacuum vessel and shield would meet this limit between 10 and 100 years after shutdown. The blanket will not meet this limit at 100 years if alumina were used, but would be well below this limit at 100 years without alumina.

The WDR limit, which is based on detailed analysis of the dose that could be received by an inadvertent intruder, is believed to be representative of a realistic criterion for LLW that would qualify for near-surface burial. In terms of WDR, ferritic steel without impurities will meet the near-surface burial criterion, but with the specified impurities, ferritic steel will be very close to this limit and in fact slightly exceeds it in the divertor wall. If a WDR less than unity is to be achieved, it is going to be critical to control impurities. In particular a few such as $\mathrm{Mo}, \mathrm{Nb}$, and $\mathrm{Ag}$ will need to be controlled to parts per million (ppm) or less. The dominant elemental WDRs given Table C.1 and the corresponding elemental concentrations given in Table A.2 provide a basis for calculationg the WDR for other $w / o$ concentrations of the alloying and impurity elements.

\section{D.2. DEMO with Reference $\mathrm{MS} / \mathrm{Li}_{17} \mathrm{~Pb}_{83} / \mathrm{H}_{2} \mathrm{O}$ Blanket Design (R2)}

The structural material in all components, except for the divertor plate, was the martensitic steel (MS) MANET. No information on impurities was found for MANET. Since activation was generally quite high without impurities, they were not considered. The structure of the divertor plate was dispersion strengthened copper. The breeder in this design is a liquid eutectic, lithium lead. Since it is a liquid, it is assumed that it would be drained from the reactor and disposed of separately from the MANET structure. Therefore, in the blanket, the structural material and lithium lead are treated as separate components, and only the structural material is included in Figures D.4-D.6.

The waste disposal rating for the various components is shown in Figure D.4., All of the components, except the divertor plate, exceed the WDR criteria of unity by an order of magnitude or more.

The WDR for MANET is dominated by the presence of molybdenum $(\mathrm{Mo})$ and niobium $(\mathrm{Nb})$. In this case, both are intentional alloys and are present in concentrations much higher than allowable levels for LLW disposal. The 
maximum concentration for the alloys $\mathrm{Mo}$ and $\mathrm{Nb}$ in this first-wall spectrum are $52 \mathrm{ppm}$ and $3.8 \mathrm{ppm}$, respectively, and in the divertor-wall spectrum are $36 \mathrm{ppm}$ and $2.6 \mathrm{ppm}$, respectively.

For the pure lithium lead breeder the WDR was 0.07 , which satisfies the WDR criterion. Impurities increased the WDR by 3.95. This was primarily due to the presence of silver (Ag), which contributed 3.56 to the WDR. The MIC for $\mathrm{Ag}$ and Mo in this blanket spectrum are $2.6 \mathrm{ppm}$ and $81 \mathrm{ppm}$, respectively.

The specific activity for the various components is shown in Figure D.5. Using the Japanese LLW limit ${ }^{12}$ for solid wastes of $1 \mathrm{Ci} / \mathrm{m}^{3}$, none of the components would be classified as LLW.

The contact dose for each component is shown in Figure D.6. Based on the IAEA proposal for a LLW limit for solid waste of $<2 \mathrm{mSv} / \mathrm{hr}^{12}$, none of the components would be classified as LLW.

MANET exceeds the LLW criteria by one or more orders of magnitude. It could not be modified to satisfy LLW criteria without significant substitution for the alloying elements, molybdenum and niobium. We understand that a lowactivation MANET is under development but were unable to obtain a composition for inclusion in this analysis. The lithium lead breeder meets the WDR limit in the pure form, but was well in excess of this value with impurities.

\section{D.3. DEMO with Reference V/Li Blanket Design (R3)}

The structural material in the first wall, divertor wall, and blanket was the vanadium alloy, $\mathrm{V}-4 \mathrm{Cr}-4 \mathrm{Ti}$. The structural material in the vacuum vessel and shield was the ferritic steel alloy. The structural material in the divertor plate was dispersion strengthened copper. The breeder in this design is a liquid metal, lithium. Since it was a liquid, it was assumed that the breeder would be drained from the reactor and disposed of separately from the vanadium structure. Therefore, in the blanket, the solid materials and the liquid lithium are treated as separate components and only the solid materials are included in Figures D.7-D.9. In these figures, "other" refers to calcium oxide $(\mathrm{CaO})$ in the blanket and lead $(\mathrm{Pb})$ in the shield.

The waste disposal rating for the various components is shown in Figure D.7. All components, except the divertor plate, will meet the WDR limit of unity. The vanadium with impurities and the calcium oxide contributed 0.02 and 0.06 , respectively, to the WDR of the solid portion of the blanket. The WDR of the liquid lithium breeder with impurities was 0.06 .

The contribution to the WDR of the primary alloying elements in vanadium is almost zero. The impurity level of $1 \mathrm{ppm} \mathrm{Nb}$ was assumed, which results in a WDR of 0.26 . The MICs for $\mathrm{Nb}, \mathrm{Si}$ and another likely impurity ${ }^{25}$, Mo in the first-wall spectrum are $97 \mathrm{ppm}, 28 \%$ and $5.2 \mathrm{ppm}$, respectively and in the divertor-wall spectrum are $71 \mathrm{ppm}, 15 \%$ and $3.8 \mathrm{ppm}$, respectively.

The specific activity for the various components is shown in Figure D.8. Using the Japanese LLW limit ${ }^{12}$ for solid wastes of $1 \mathrm{Ci} / \mathrm{m}^{3}$, vanadium will be 
classified as LLW some time between 10-100 years after shutdown. If this criteria were to be applied, the pure lithium would be classified as LLW, but with the specified impurities, it would not be classified as LLW. The presence of calcium oxide $(\mathrm{CaO})$ as a reflector in the blanket would prevent the blanket from being classified as LLW based on this criterion. The vacuum vessel and shield would not meet this criterion even at 100 years because of the impurities in the ferritic steel used as structural material.

The contact dose for each component is shown in Figure D.9. Using the IAEA proposal for a LLW limit for solid waste of $<2 \mathrm{mSv} / \mathrm{hr}^{12}$, all components, except the divertor plate, would satisfy this criterion between 10 and 100 years after shutdown.

Vanadium ( $\mathrm{V}-4 \mathrm{Cr}-4 \mathrm{Ti})$ appears to be a very good candidate for meeting all low-level waste criteria. The pure material is very low activation and the activation of this material will be dominated by impurities, but with reasonable levels of impurities the WDRs1.0 criterion for near-surface burial should still be satisfied.

\section{D.4. DEMO with Reference $\mathrm{SiC} / \mathrm{Li}_{2} \mathrm{ZrO}_{3} / \mathrm{He}$ Blanket Design (R4)}

The structural material in the first wall, divertor wall, and blanket was silicon carbide $(\mathrm{SiC})$. The structural material in the vacuum vessel and shield was the ferritic steel alloy given in Table A.2. The structural material in the divertor plate was dispersion strengthened copper. In Figures D.10-D.12, "other" refers to lithium zirconate $\left(\mathrm{Li}_{2} \mathrm{ZrO}_{3}\right)$ and beryllium $(\mathrm{Be})$ in the blanket, and to lead $(\mathrm{Pb})$ in the shield.

The waste disposal rating for the various components is shown in Figure D.10. The silicon carbide design almost qualifies for LLW near-surface burial. The first wall, divertor wall, and divertor plate exceeded the WDR limit of unity. The WDR was 1.56 for the first wall and 2.71 for the divertor wall. The contribution to the WDR was primarily from silicon. The impurities were insignificant for the WDR. In the AIRIES-I report ${ }^{5}$, a WDR of 0.12 was reported for the first wall using silicon carbide. Fetter ${ }^{13}$ reports a limiting concentration of $30 \%$ for silicon in the first wall of a design irradiated to $20 \mathrm{MW}-\mathrm{yr} / \mathrm{m}^{2}$, which would correspond approximately to a WDR $=1.1$ based on the density of silicon in silicon carbide. The AIRIES-I report used the same specific activity limits (Table B.1) as used in this analysis and an older version of the REAC code and associated cross sections ${ }^{5}$. Fetter ${ }^{33}$ used REAC 2 and associated cross sections. The difference between this analysis and Fetter's, which are in reasonable agreement, and the AIRIES results for the WDR of silicon carbide may be due to differences in the activation cross sections in successive versions of REAC. The discrepancy needs to be resolved.

The blanket with the isotopically tailored zirconium satisfies the WDRs 1 criterion. In the AIRIES-I report ${ }^{5}$, the cost of isotopically tailoring the zirconium for the breeding material was estimatd to be $\$ 2097 / \mathrm{kg}^{5}$. Isotopically tailoring is 
necessary for the blanket to meet LLW criteria ${ }^{5}$, but the cost would certainly be a factor in choosing this material.

The specific activity for the various components is shown in Figure D.11. Using the Japanese low-level waste (LLW) limit ${ }^{12}$ for solid wastes of $1 \mathrm{Ci} / \mathrm{m}^{3}$, the first wall will meet this criterion between 10 and 100 years after shutdown. The vacuum vessel and shield will not meet this criterion until after more than 100 years after shutdown, and all other components will not meet this criterion. The beryllium in the blanket causes the blanket to not meet this criterion.

The contact dose for each component is shown in Figure D.12. Based on the IAEA proposal for a LLW limit for solid waste of $<2 \mathrm{mSv} / \mathrm{hr}^{12}$, the first wall, divertor wall, and divertor plate would not meet this criterion. The blanket would meet this criterion between 1 and 10 years after shutdown, and the vacuum vessel and shield between 10 and 100 years after shutdown.

\section{D.5. DEMO with Variant $\mathrm{V} / \mathrm{Li}_{2} \mathrm{O} / \mathrm{H}_{2} \mathrm{O}$ Blanket Design (V1)}

A DEMO design similar to design $\mathrm{R} 1$, except that $\mathrm{V}-4 \mathrm{Cr}-4 \mathrm{Ti}$ instead of ferritic steel was used as the structural material in the first wall, divertor wall, and blanket, was developed. The structural material in the vacuum vessel and shield remained the ferritic steel alloy, because of the expense of vanadium. The structural material in the divertor plate was dispersion strengthened copper. In Figures D.13-D.15, "other" refers to lithium oxide $\left(\mathrm{Li}_{2} \mathrm{O}\right)$ and beryllium $(\mathrm{Be})$ in the blanket, and to lead $(\mathrm{Pb})$ in the shield.

The waste disposal rating for the various components is shown in Figure D.13. All components, except the divertor plate, will meet the WDR limit of unity.

The contribution to the WDR of the primary alloying elements in vanadium is almost zero. An impurity level of $1 \mathrm{ppm} \mathrm{Nb}$ was assumed, which still meets the WDR limit. The WDR of the blanket is 0.17 , which is from the beryllium $(\mathrm{WDR}=0.08)$ and the lithium oxide $(\mathrm{WDR}=0.09)$ in the blanket.

The MICs for $\mathrm{Nb}, \mathrm{Si}$ and another likely impurity ${ }^{25}, \mathrm{Mo}$ in the first-wall spectrum are $98 \mathrm{ppm}, 29 \%$ and $5.0 \mathrm{ppm}$, respectively and in the divertor-wall spectrum are $73 \mathrm{ppm}, 13 \%$ and $3.7 \mathrm{ppm}$, respectively:

The specific activity for the various components is shown in Figure D.14. Using the Japanese LLW limit for solid wastes of $1 \mathrm{Ci} / \mathrm{m}^{3}{ }^{12}$, the first wall and divertor wall would be classified as LLW between 10 and 100 years after shutdown. The blanket would not be classified as LLW because of the beryllium and lithium oxide. The vacuum vessel and shield would not meet this criterion because of the use of ferritic steel as a structural material.

The contact dose for each component is shown in Figure D.15. Using the IAEA proposal for a LLW limit for solid waste of $<2 \mathrm{mSv} / \mathrm{hr}^{12}$, the first wall and divertor wall would almost qualify as LLW between 1 and 10 years after shutdown. The blanket would be classified as LLW at 10 years after shutdown. All components would be classified as LLW at 100 years after shutdown using 
this criteria, except the divertor plate and the divertor wall, the latter of which would still have a contact dose of $2.1 \mathrm{mSv} / \mathrm{hr}$, only slightly greater than this criterion.

Replacement of the ferritic steel (FeS) by $\mathrm{V}-4 \mathrm{Cr}-4 \mathrm{Ti}(\mathrm{V})$ in the reference $\mathrm{FeS} / \mathrm{Li}_{2} \mathrm{O} / \mathrm{H}_{2} \mathrm{O}$ design leads to a design with attractive low activation properties in those components in which the replacement was made. If the replacement was also made in the divertor, all components would meet the WDRs 1.0 criteria for near-surface burial.

\section{D.6. DEMOs with Variant Austenitic Stainless $\mathrm{Steel} / \mathrm{Li}_{2} \mathrm{O} / \mathrm{H}_{2} \mathrm{O}$ Blanket Designs (V2,V3,V4)}

Austenitic stainless steels have been widely used in industry and have an extensive database. Unless an advanced structural material with low activation properties is successfully developed and tested by the time of construction, austenitic steel structure would have to be used for DEMO. The existing materials of this type are all high activation and clearly not candidates for nearsurface burial, even if irradiated to relatively low fluences. DEMO designs similar to design R1, except that austenitic stainless steels (316SS, PCA, VA64) were used as structural materials instead of ferritic steel, were developed. The divertor plate was still dispersion strengthened copper. Figures D.16-D.18 show the properties of the $316 \mathrm{SS}$ variant. The other austenitic materials, PCA and VA64, showed similar activation properties.

The waste disposal rating for the various components is shown in Figure D.16. All components have WDR $>>1$. This was true for all three austenitic materials considered. The activation of the base material was so high for these materials that impurities were not considered.

The WDR for $3165 S$ and PCA resulted nearly $100 \%$ from Mo, while for $\mathrm{VA64}$, it was primarily from $\mathrm{Mo}$ and $\mathrm{Nb}$. The maximum allowable concentration of Mo in the $316 \mathrm{SS}$ first wall and divertor wall spectra are $170 \mathrm{ppm}$ and $90 \mathrm{ppm}$, respectively. The maximum concentration of $\mathrm{Mo}, \mathrm{Nb}$ and $\mathrm{Al}$ in the PCA first-wall spectrum are $95 \mathrm{ppm}, 7.2 \mathrm{ppm}$ and $0.17 \%$, respectively, and in divertor-wall spectrum are $63 \mathrm{ppm}, 4.6 \mathrm{ppm}$ and $0.11 \%$, respectively. The maximum concentration of $\mathrm{Mo}, \mathrm{Nb}$ and $\mathrm{W}$ in the VA64 first-wall spectrum are $140 \mathrm{ppm}, 12 \mathrm{ppm}$ and $16 \%$, respectively, and in the divertor-wall spectrum are $95 \mathrm{ppm}, 8.1 \mathrm{ppm}$ and $11 \%$, respectively.

A low-activation version of VA64 was proposed ${ }^{29}$ which contains $0.2 \mathrm{ppm}$ $\mathrm{Nb}, 50 \mathrm{ppm} \mathrm{Mo}$, and $1.94 \% \mathrm{~W}$. The estimated WDRs for the low-activation version of VA64 in the first-wall and divertor-wall are 0.5 and 0.7 , for the pure VA64. Both the low-activation VA64 and the ferritic steel contain $2 \% \mathrm{~W}$, which is the only element that will contribute significantly to the WDR in the pure structure.

The specific activities for the various components are shown in Figure D.17. Using the Japanese LLW limit ${ }^{12}$ for solid wastes of $1 \mathrm{Ci} / \mathrm{m}^{3}$, all 
components would exceed the LLW limit by orders of magnitude. The specific activities are still quite high even after long decay times, in excess of $100 \mathrm{Ci} / \mathrm{m}^{3}$ in the first wall for all three austenitic materials at 10,000 years after shutdown.

The contact dose for each component is shown in Figure D.18. Using the IAEA proposal for a LLW limit for solid waste of $<2 \mathrm{mSv} / \mathrm{hr}^{12}$, all components exceed this limit until 100 years or more after shutdown.

The austenitic stainless steels clearly would be classified as high-level waste and lead to all of the difficulties associated with the requirement for deep geologic disposal.

\section{D.7. Maximum Impurity Concentrations}

Maximum Impurity Concentration (MIC) has been defined as the concentration of an impurity which would increase the WDR of the pure structure to unity. The MIC depends, of course, on the alloying composition of the pure structure and on the neutron spectrum and the neutron fluence experienced by the component. For convenience, the MICs quoted previously in this appendix are collected in Table D.1. The requirement for WDR $\leq 1$ for the component is that the ratio of the actual impurity concentration to the MIC for that impurity, summed over all impurities present, be less than or equal to unity.

\section{REFERENCES}

1. D.M Meade, et al., " Advanced Tokamak Modes and ITER," Comments on Plasma Physics, to be published.

2. S. Mori et al. "Blanket and Divertor Design for the Steady State Tokamak Reactor (SSTR)," Fusion Engineering and Design, 18, 249, 1991.

3. L. Giancarli, "Water-Cooled Pb-17Li Demo Blanket Line EU Reference Conceptual Design and Performance Presentation," Commissariat a l'Energie Atomique, DMT 94/538 (SERMA/LCA/1678), 1994.

4. D. Ehst, et al., "Tokamak Power Systems Studies - FY1986: A Second Stability Power Reactor," Argonne National Laboratory, ANL/FPP/86-1, 1986.

5. "The AIRIES-I Tokamak Reactor Study Final Report 1991," UCLA-PPG-1323, 1991.

6. P.H. Rebut, et al., "The ITER EDA Outline Design," Proceedings of the 15th International Conference on Plasma Physics and Controlled Nuclear Fusion Research, IAEA-CN-60/E-1-I-3, (Seville 1994) IAEA, Vienna, 1995. 
7. W.M. Stacey, "Tokamak Demonstration Reactors," Georgia Tech report GTFR118 ,1995; also Nuclear Fusion, to be published.

8. R. J. Thome, "Magnet Design for the International Thermonuclear Experimental Experimental Reactor," Fusion Technology 26, 465, 1994.

9. ITER-CDA Team, "Physics," ITER Doc. Series 21, IAEA, Vienna, 1991.

10. ITER-CDA Team, "ITER Current Drive and Heating System," ITER Doc. Series 32, IAEA, Vienna, 1991.

11. ITER-EDA Team, Presentations to Technical Advisory Committee, 1993-94.

12. ITER-CDA Team "ITER Safety," ITER Doc. Series 36, IAEA, Vienna, 1991.

13. S. Fetter, E.T. Cheng, F.M. Mann, "Long-term Radioactive Waste From Fusion Reactors: Part II," Fusion Engineering and Design 13, 239, 1990.

14. Code of Federal Regulations, Licensing Requirements for Land Disposal of Radioactive Waste, Title 10, Part 61, Washington, DC, Nuclear Regulatory Commission.

15. F.M. Mann, Westinghouse, personal communication, $\left(R E A C^{*} 3\right.$ is an upgrade version of "REAC*2: Users Manual and Code Description," Westinghouse Hanford Company, WHC-EP-0282, 1989).

16. "TWODANT-SYS One- and Two-Dimensional, Multigroup, DiscreteOrdinates Transport Code System," Oak Ridge National Laboratory, CCC-547, 1992.

17. R.E. MacFarlane, "MATXS10 30-Group Neutron, 12 Group Photon Cross Sections from ENDF/B-VI in MATXS Format," Oak Ridge National Laboratory, DLC-176, 1994.

18. R.E. MacFarlane, "TRANSX 2.0 Code System to Produce Neutron, Photon, and Particle Transport Tables for Discrete-Ordinates and Diffusion Codes from Cross Sections in MATXS Format," Oak Ridge National Laboratory, PSR-317, 1992.

19. "Microshield Version 3," Grove Engineering, Inc., 1987.

20. R.L. Klueh, Oak Ridge National Laboratory, personal communications, data from "Nuclear Systems Materials Handbook," Rev. 2.

21. R.L. Klueh, Oak Ridge National Laboratory, personal communications. 
22. D.S. Gelles, "Microstructural Examination of Commercial Ferritic Alloys at 200 DPA," Semiannual Progress Report, DOE/ER-0313/16, (1994).

23. E.E. Bloom, R.L. Klueh, A.F. Rowcliffe, D.S. Gelles, personal communications presentation at ISCUS/US-TAC Meeting, UCLA August 16-17, 1993.

24. M. Küchle, "Material Data Base for the NET Test Blanket Design Studies," KfK report, February 1991.

25. D. Smith, Argonne National Laboratory, personal communications (1994-95).

26. S.A. Fetter, "Radiological Hazards of Fusion Reactors: Models and Comparisons," Ph. D dissertation, UC-Berkeley, 1985.

27. ITER CDA Team, "Material Data Base," ITER Doc. Series, 29, IAEAA, Vienna, 1991.

28. A.P. Kinzig, et al., "Safety and Environmetal Comparison of Stainless Steel with Alternative Structural Materials for Fusion Reactors," Fusion Technology, 26, 79, 1994.

29. M. Zucchetti, M. Zublena, "A Study on the Prospects of a New Low Activation Austenitic Stainless Steel for Fusion Applications," Proceedings of the 15th Symposium on Fusion Technology 991, North-Holland, 1989.

30. G. Piatti, P. Schiller, "Thermal and Mechanical Properties of the Cr-Mn (Nifree) Austenitic Steels for Fusion Reactor Applications," Lournal of Nuclear Materials, 144-143, 417, 1986.

31. S.J. Zinkle, S.A. Fabritsiev, "Copper Alloys for High Heat Flux Structure Applications," Fusion Reactor Materials Semiannual Progress Report, DOE/ER0313/16, 1994.

32. J.P. Holdren, et al., "Exploring the Competitive Potential of Magnetic Fusion Energy: the Interaction of Economics with Safety and Environmental Characteristics," Fusion Technology 13, 7, 1988.

33. S. Fetter, E.T. Cheng, F.M. Mann, "Long-term Radioactivity In Fusion Reactors," Fusion Engineering and Design, 6, 123, 1990.

34. E. A. Hoffman, "Low Activation Tokamak Reactors," MS Thesis, Georgia Institute of Technology, 1995. 


\section{Acknowledgement}

We gratefully acknowledge the materials or design information provided by E.E. Bloom, R.L. Klueh, D.L. Smith, H. Attaya, M.A. Futterer, and C. Wong. We are grateful to F. Mann for providing an updated version of the REAC code. Discussions with G. Nardella, W. Wiffen, S. Berk and R. Price resulted in useful insights during the course of the work.

The work was supported by the US Dept. of Energy under grant \#DEFG05-87ER52141.

This paper was adapted from an MS Thesis ${ }^{34}$ by the first author, where more detailed information may be found. 
Table 1

Compositions and Dimensions of the Reference Reactor Designs

\begin{tabular}{|c|c|c|c|c|c|c|c|c|}
\hline & \multicolumn{2}{|c|}{$\overline{\mathrm{R} 1}$} & \multicolumn{2}{|c|}{$\mathrm{R} 2$} & \multicolumn{2}{|c|}{ R3 } & \multicolumn{2}{|c|}{$\mathrm{R4}$} \\
\hline Component & Materials & $\begin{array}{c}\text { Thickness } \\
\text { (cm) }\end{array}$ & Materials & $\begin{array}{c}\text { Thickness } \\
(\mathrm{cm})\end{array}$ & Materials & $\begin{array}{c}\text { Thickness } \\
\text { (cm) }\end{array}$ & Materials & $\begin{array}{c}\text { Thickness } \\
(\mathrm{cm})\end{array}$ \\
\hline First Wall & $\begin{array}{c}\text { Ferritic } \\
\text { Steel/ } \\
\mathrm{H}_{2} \mathrm{O}\end{array}$ & 2.68 & $\begin{array}{c}\text { MANET } \\
\mathrm{H}_{2} \mathrm{O}\end{array}$ & 2.24 & $\mathrm{~V} / \mathrm{Li}$ & 2.52 & $\begin{array}{c}\text { Silicon } \\
\text { Carbide/ } \\
\mathrm{He}\end{array}$ & 2.43 \\
\hline $\begin{array}{c}\text { Divertor } \\
\text { Plate }\end{array}$ & $\begin{array}{c}\text { DSCu/ } \\
\mathrm{H}_{2} \mathrm{O} \\
\end{array}$ & 4.24 & $\begin{array}{c}\text { DSCu/ } \\
\mathrm{H}_{2} \mathrm{O}\end{array}$ & 4.32 & $\begin{array}{c}\text { DSCu/ } \\
\mathrm{H}_{2} \mathrm{O}\end{array}$ & 4.43 & $\begin{array}{c}\text { DSCu/ } \\
\text { He }\end{array}$ & 3.82 \\
\hline $\begin{array}{c}\text { Divertor } \\
\text { Wall }\end{array}$ & $\begin{array}{c}\text { Ferritic } \\
\text { Steel/ } \\
\mathrm{H}_{2} \mathrm{O}\end{array}$ & 268 & $\begin{array}{c}\text { MANET } \\
/ \mathrm{H}_{2} \mathrm{O}\end{array}$ & 2.24 & $\mathrm{~V} / \mathrm{Li}$ & 2.52 & $\begin{array}{c}\text { Silicon } \\
\text { Carbide/ } \\
\mathrm{He}\end{array}$ & 2.43 \\
\hline Blanket & $\begin{array}{c}\text { Ferritic } \\
\text { Steel/ } \\
\mathrm{H}_{2} \mathrm{O} / \\
\mathrm{Li}_{2} \mathrm{O} / \mathrm{Be}\end{array}$ & 44.0 & $\begin{array}{c}\text { MANET } \\
/ \mathrm{H}_{2} \mathrm{O} \\
\mathrm{Li}_{17} \mathrm{~Pb}_{\mathrm{B} 3}\end{array}$ & 40.0 & $\begin{array}{l}\mathrm{V} / \mathrm{Li} / \\
\mathrm{CaO}\end{array}$ & 85.5 & $\begin{array}{l}\text { Silicon } \\
\text { Carbide/ } \\
\mathrm{He} / \mathrm{Be} / \\
\mathrm{Li}_{2} \mathrm{Zr} \mathrm{O}{ }_{3}\end{array}$ & 96.0 \\
\hline $\begin{array}{c}\text { Vacuum } \\
\text { Vessel }\end{array}$ & $\begin{array}{c}\text { Ferritic } \\
\text { Steel }\end{array}$ & 2.38 & MANET & 1.85 & $\begin{array}{c}\text { Ferritic } \\
\text { Steel }\end{array}$ & 2.84 & $\begin{array}{c}\text { Ferritic } \\
\text { Steel }\end{array}$ & 2.94 \\
\hline Shield & $\begin{array}{l}\text { Ferritic } \\
\text { Steel/ } \\
\mathrm{H}_{2} \mathrm{O} / \mathrm{Pb}\end{array}$ & 63.5 & $\begin{array}{c}\text { MANET } \\
/ \mathrm{H}_{2} \mathrm{O} \\
/ \mathrm{Pb}\end{array}$ & 58.1 & $\begin{array}{c}\text { Ferritic } \\
\text { Steel/ } \\
\mathrm{H}_{2} \mathrm{O} / \mathrm{Pb}\end{array}$ & $\overline{47.4}$ & $\begin{array}{c}\text { Ferritic } \\
\text { Steel/ } \\
\mathrm{H}_{2} \mathrm{O} / \mathrm{Pb}\end{array}$ & 41.5 \\
\hline
\end{tabular}

1. DSCu - Dispersion Strengthened Copper 
Table 2

Compositions and Dimensions of the Variant Reactor Designs

\begin{tabular}{|c|c|c|c|c|c|c|c|c|}
\hline & \multicolumn{2}{|c|}{$\overline{\mathrm{V} 1}$} & \multicolumn{2}{|c|}{$\mathrm{V} 2$} & \multicolumn{2}{|c|}{ V3 } & \multicolumn{2}{|c|}{ V4 } \\
\hline Component & Materials & $\begin{array}{c}\text { Thickness } \\
\text { (cm) }\end{array}$ & Materials & $\begin{array}{l}\text { Thickness } \\
(\mathrm{cm})\end{array}$ & Materials & $\begin{array}{c}\text { Thickness } \\
(\mathrm{cm})\end{array}$ & Materials & $\begin{array}{c}\text { Thickness } \\
(\mathrm{cm})\end{array}$ \\
\hline First Wall & $\mathrm{V} / \mathrm{H}_{2} \mathrm{O}$ & 2.42 & $\begin{array}{c}316 \mathrm{SS} / \\
\mathrm{H}_{2} \mathrm{O}\end{array}$ & 3.50 & $\begin{array}{l}\mathrm{PCA} / \\
\mathrm{H}_{2} \mathrm{O}\end{array}$ & 3.52 & $\begin{array}{c}\mathrm{VA} 64 / \\
\mathrm{H}_{2} \mathrm{O}\end{array}$ & 1.50 \\
\hline $\begin{array}{c}\text { Divertor } \\
\text { Plate }\end{array}$ & $\begin{array}{c}\text { DSCu/ } \\
\mathrm{H}_{2} \mathrm{O}\end{array}$ & 4.23 & $\begin{array}{c}\overline{\mathrm{DSCu} /} \\
\mathrm{H}_{2} \mathrm{O}\end{array}$ & 4.62 & $\begin{array}{c}\text { DSCu/ } \\
\mathrm{H}_{2} \mathrm{O}\end{array}$ & 4.65 & $\begin{array}{c}\text { DSCu/ } \\
\mathrm{He}\end{array}$ & 4.24 \\
\hline $\begin{array}{c}\text { Divertor } \\
\text { Wall }\end{array}$ & $\begin{array}{c}\text { Ferritic } \\
\text { Steel/ } \\
\mathrm{H}_{2} \mathrm{O}\end{array}$ & 2.42 & $\begin{array}{c}316 \mathrm{SS} / \\
\mathrm{H}_{2} \mathrm{O}\end{array}$ & 3.50 & $\begin{array}{l}\mathrm{PCA} / \\
\mathrm{H}_{2} \mathrm{O}\end{array}$ & 3.52 & $\begin{array}{c}\text { VA64/ } \\
\mathrm{H}_{2} \mathrm{O}\end{array}$ & 1.50 \\
\hline Blanket & $\begin{array}{l}\mathrm{V} / \mathrm{H}_{2} \mathrm{O} / \\
\mathrm{Li}_{2} \mathrm{O} / \mathrm{Be}\end{array}$ & $\overline{37.3}$ & $\begin{array}{c}316 \mathrm{SS} / \\
\mathrm{H}_{2} \mathrm{O} / \\
\mathrm{Li}_{2} \mathrm{O} / \mathrm{Be}\end{array}$ & 42.0 & $\begin{array}{c}\mathrm{PCA} / \\
\mathrm{H}_{2} \mathrm{O} / \\
\mathrm{Li}_{2} \mathrm{O} / \mathrm{Be}\end{array}$ & 36.0 & $\begin{array}{c}\mathrm{VA64/} \\
\mathrm{H}_{2} \mathrm{O} / \\
\mathrm{Li}_{2} \mathrm{O} / \mathrm{Be}\end{array}$ & 425 \\
\hline $\begin{array}{l}\text { Vacuum } \\
\text { Vessel }\end{array}$ & $\begin{array}{l}\text { Ferritic } \\
\text { Steel }\end{array}$ & 2.34 & $316 S S$ & 3.61 & PCA & 3.55 & VA64 & 1.16 \\
\hline Shield & $\begin{array}{c}\text { Ferritic } \\
\text { Steel/ } \\
\mathrm{H}_{2} \mathrm{O} / \mathrm{Pb}\end{array}$ & 72.1 & $\begin{array}{c}316 S S / \\
\mathrm{H}_{2} \mathrm{O} / \mathrm{Pb}\end{array}$ & 60.4 & $\begin{array}{c}\mathrm{PCA} / \\
\mathrm{H}_{2} \mathrm{O} / \mathrm{Pb}\end{array}$ & 63.9 & $\begin{array}{c}\mathrm{VA64/} \\
\mathrm{H}_{2} \mathrm{O} / \mathrm{Pb}\end{array}$ & 67.9 \\
\hline
\end{tabular}

1. DSCu - Dispersion Strengthened Copper 
Table 3

DEMO Reactor Parameters

\begin{tabular}{|c|c|c|c|c|c|c|c|c|}
\hline Design & R1 & R2 & R3 & R4 & V1 & V2 & V3 & V4 \\
\hline $\begin{array}{c}\text { Fusion } \\
\text { Power } \\
\text { (MW) }\end{array}$ & 1500 & 1500 & 1500 & 1500 & 1500 & 1500 & 1500 & 1500 \\
\hline $\begin{array}{c}\text { Lifetime } \\
\text { (EFPY) }\end{array}$ & 10 & 10 & 10 & 10 & 10 & 10 & 10 & 10 \\
\hline $\begin{array}{c}\text { Major } \\
\text { Radius } \\
\text { (m) }\end{array}$ & 6.25 & 6.22 & 6.59 & 6.67 & 6.26 & 7.38 & 7.37 & 6.26 \\
\hline $\begin{array}{c}\text { Minor } \\
\text { Radius } \\
\text { (m) }\end{array}$ & 1.84 & 1.81 & 1.97 & 1.99 & 1.85 & 2.41 & 2.41 & 1.84 \\
\hline $\begin{array}{c}\text { Plasma } \\
\text { Elongation }\end{array}$ & 1.8 & 1.8 & 1.8 & 1.8 & 1.8 & 1.8 & 1.8 & 1.8 \\
\hline $\begin{array}{c}\text { Maximum } \\
\text { Toroidal } \\
\text { Field (T) }\end{array}$ & 12 & 12 & 12 & 12 & 12 & 12 & 12 & 12 \\
\hline $\begin{array}{c}\text { Plasma } \\
\text { Current } \\
(\text { MA) }\end{array}$ & 12.9 & 13.0 & 13.1 & 13.1 & 12.9 & 15.5 & 15.6 & 12.9 \\
\hline \begin{tabular}{c}
$\beta_{N}$ \\
\hline H ITER89
\end{tabular} & 3.89 & 3.75 & 4.00 & 4.00 & 3.92 & 2.96 & 2.93 & 3.90 \\
\hline $\begin{array}{c}\text { Auxiliary } \\
\text { Power } \\
(\text { MW) }\end{array}$ & 100 & 100 & 100 & 100 & 100 & 100 & 100 & 100 \\
\hline $\begin{array}{c}\text { Maximum } \\
\text { First Wall } \\
\text { Heat Flux } \\
\text { (MW/m }{ }^{2} \text { ) }\end{array}$ & 0.695 & 0.712 & 0.618 & 0.603 & 0.692 & 0.450 & 0.450 & 0.694 \\
\hline $\begin{array}{c}\text { Average } \\
\text { First Wall } \\
\text { Neutron } \\
\text { Load } \\
\left(\text { MW/m }{ }^{2}\right)\end{array}$ & 1.80 & 1.84 & 1.60 & 1.56 & 1.79 & 1.16 & 1.16 & 1.80 \\
\hline
\end{tabular}


Table 4

Low-Level Waste Criteria ${ }^{12}$

\begin{tabular}{|l|l|l|}
\hline Country & Waste & Criteria \\
\hline \hline USA & & Isotope Specific \\
\hline \multirow{4}{*}{ Japan } & Solid & $1-10^{-3} \mathrm{Ci} / \mathrm{m}^{3}$ \\
\cline { 2 - 3 } & Liquid & $10^{-3}-10^{-6} \mathrm{Ci} / \mathrm{m}^{3}$ \\
\cline { 2 - 3 } & Gaseous & $10^{-6}-10^{-9} \mathrm{Ci} / \mathrm{m}^{3}$ \\
\hline \multirow{3}{*}{ U.K. } & Alpha & $<0.11 \mathrm{Ci} / \mathrm{t}$ \\
\cline { 2 - 3 } & Beta, Gamma & $<0.32 \mathrm{Ci} / \mathrm{t}$ \\
\hline France & & Isotope Specific \\
\hline FRG & & Isotope Specific \\
\hline Sweden & Alpha & $0.27 \mathrm{Ci}$ total site \\
\cline { 2 - 3 } & Beta, Gamma & $270 \mathrm{Ci}$ total site \\
\hline \multirow{4}{*}{ USSR } & Solid Alpha & $0.01-0.0001 \mathrm{Ci} / \mathrm{t}$ \\
\cline { 2 - 3 } & & $0.1-0.001 \mathrm{Ci} / \mathrm{t}$ \\
\cline { 2 - 3 } & & $0.3-0.0003 \mathrm{mSv} / \mathrm{hr}$ \\
\cline { 2 - 3 } & Giquid & $<10^{-2} \mathrm{Ci} / \mathrm{m}^{3}$ \\
\hline \multirow{3}{*}{ IAEA } \\
proposal & Solid & $<2 \mathrm{mSv} / \mathrm{hr}$ \\
\cline { 2 - 3 } & Liquid & $10^{-3}-10^{-6} \mathrm{Ci} / \mathrm{m}^{3}$ \\
\cline { 2 - 3 } & Gaseous & $<10^{-10} \mathrm{Ci} / \mathrm{m}^{3}$ \\
\hline
\end{tabular}


Table A.1

Structural Material Thermo-Mechanical Properties

\begin{tabular}{|c|c|c|c|c|c|c|c|}
\cline { 2 - 8 } \multicolumn{1}{c|}{} & $\mathrm{HT}-9 \mathrm{~m}^{20-23}$ & $\mathrm{MANET}^{24}$ & $\mathrm{~V}-4 \mathrm{CrTi}^{25}$ & $\mathrm{SiC}^{5}$ & $316 \mathrm{SS}^{25.26}$ & $\mathrm{VA}^{2930}$ & D.S. Copper $^{27.31}$ \\
\hline $\mathrm{US}(\mathrm{Pa})$ & $3.96 \mathrm{E}+08$ & $4.94 \mathrm{E}+08$ & $4.40 \mathrm{E}+08$ & & $4.85 \mathrm{E}+08$ & & $2.50 \mathrm{E}+08$ \\
\hline $\mathrm{YS}(\mathrm{Pa})$ & $3.07 \mathrm{E}+08$ & $4.26 \mathrm{E}+08$ & $2.70 \mathrm{E}+08$ & & $1.65 \mathrm{E}+08$ & & $2.20 \mathrm{E}+08$ \\
\hline $\begin{array}{c}\text { Stress Limit } \\
(\mathrm{Pa})\end{array}$ & $1.02 \mathrm{E}+08$ & $1.42 \mathrm{E}+08$ & $9.00 \mathrm{E}+07$ & $1.40 \mathrm{E}+08$ & $5.50 \mathrm{E}+07$ & $2.70 \mathrm{E}+08$ & $8.33 \mathrm{E}+08$ \\
\hline $\begin{array}{c}\text { Expansion } \\
\text { Coff. (1/K) }\end{array}$ & $1.23 \mathrm{E}-05$ & $1.22 \mathrm{E}-05$ & $1.04 \mathrm{E}-05$ & $4.40 \mathrm{E}-06$ & $1.80 \mathrm{E}-05$ & $1.64 \mathrm{E}-05$ & $1.85 \mathrm{E}-05$ \\
\hline $\begin{array}{c}\text { Elongation } \\
\text { Modulus (Pa) }\end{array}$ & $1.81 \mathrm{E}+11$ & $1.81 \mathrm{E}+11$ & $1.12 \mathrm{E}+11$ & $3.64 \mathrm{E}+11$ & $1.66 \mathrm{E}+11$ & $1.67 \mathrm{E}+11$ & $9.93 \mathrm{E}+10$ \\
\hline $\begin{array}{c}\text { Thermal } \\
\text { Conductivity } \\
(W / m-K)\end{array}$ & 30.0 & 26.2 & 34.0 & 15.0 & 14.8 & 25.2 & 288.3 \\
\hline $\begin{array}{c}\text { Poisson's } \\
\text { ratio }\end{array}$ & 0.3 & 0.30 & 0.37 & 0.16 & 0.27 & 0.283 & 0.33 \\
\hline Temp (C) & 500 & 500 & 600 & 1000 & 400 & 500 & 500 \\
\hline cpa limit & 200 & 200 & 200 & 200 & 60 & 60 & 150 \\
\hline
\end{tabular}


Table A.2

Structural Material Compositions

\begin{tabular}{|c|c|c|c|c|c|c|c|c|}
\hline \multirow{2}{*}{\multicolumn{2}{|c|}{$\frac{\text { Ferritic Steel }^{23}}{7.57 \mathrm{~g} / \mathrm{cm}^{\wedge} 3}$}} & \multicolumn{2}{|c|}{$\mathrm{MANET}^{24}$} & \multicolumn{2}{|c|}{$\mathrm{V}-4 \mathrm{Cr}-4 \mathrm{Ti}^{25}$} & \multicolumn{3}{|c|}{ Silicon Carbide ${ }^{5}$} \\
\hline & & \multicolumn{2}{|c|}{$7.76 \mathrm{~g} / \mathrm{cm}^{\wedge} 3$} & \multicolumn{2}{|c|}{$5.398 \mathrm{~g} / \mathrm{cm}^{\wedge} 3$} & \multicolumn{3}{|c|}{$2.50 \mathrm{~g} / \mathrm{cm}^{\wedge} 3$} \\
\hline & $w / o$ & & $w / o$ & & $w / o$ & & $a / o$ & \\
\hline $\mathrm{Fe}$ & Remainder & $\overline{\mathrm{Fe}}$ & Remainder & $\mathrm{V}$ & Remainder & $\mathrm{Si}$ & 50 & \\
\hline $\bar{C}$ & $\begin{array}{l}0.08-0.12 \\
(0.1)\end{array}$ & C & 0.13 & $\overline{C r}$ & 4 & C & 50 & \\
\hline$\overline{\mathrm{Si}}$ & $\begin{array}{c}0.01-0.06 \\
(0.035)\end{array}$ & $\overline{\mathrm{Cr}}$ & 10.6 & $\mathrm{Ti}$ & $\overline{4}$ & \multicolumn{3}{|c|}{ Impurities } \\
\hline$\overline{C r}$ & $\begin{array}{l}7.5-8.5 \\
(8.0)\end{array}$ & $\overline{\mathrm{Ni}}$ & 0.87 & $\mathrm{Si}$ & 0.05 & & AIRIES-I ${ }^{5}$ & Fetter $^{26}$ \\
\hline $\bar{W}$ & $\begin{array}{l}1.8-2.2 \\
(2.0)\end{array}$ & $\mathrm{Mo}$ & 0.77 & \multicolumn{2}{|c|}{ impurities $^{25}$} & & wppm & appm \\
\hline $\bar{V}$ & $\begin{array}{l}0.15-0.25 \\
(0.2)\end{array}$ & $\mathrm{V}$ & 0.22 & $\mathrm{Nb}$ & $1 \mathrm{ppm}$ & $\mathrm{Fe}$ & 11 & 1 \\
\hline $\mathrm{Ta}$ & $\begin{array}{l}0.01-0.06 \\
(0.035)\end{array}$ & $\mathrm{Nb}$ & 0.16 & & & $\mathrm{Co}$ & 3 & 0.2 \\
\hline \multicolumn{2}{|c|}{\begin{tabular}{l|l} 
Impurities $^{23}$ & $w / o$
\end{tabular}} & $\mathrm{Si}$ & 0.37 & & & $\mathrm{Na}$ & & 0.045 \\
\hline $\mathrm{Mn}$ & $\begin{array}{l}<0.5 \\
(0.5)\end{array}$ & $\overline{\mathrm{Mn}}$ & 0.82 & & & $\bar{K}$ & & 0.06 \\
\hline $\bar{P}$ & $\begin{array}{l}<0.01 \\
(0.01)\end{array}$ & S & 0.004 & & & $\overline{\mathrm{Sc}}$ & & 0.04 \\
\hline $\bar{S}$ & $\begin{array}{l}<0.01 \\
(0.01)\end{array}$ & $\bar{P}$ & 0.005 & & & $\mathrm{Mn}$ & & 0.02 \\
\hline Mo & $\begin{array}{l}\text { LAP } \\
\text { (4 ppm) }\end{array}$ & $\bar{B}$ & 0.0085 & & & $\mathrm{Cr}$ & & 1 \\
\hline$\overline{\mathrm{Ni}}$ & $\begin{array}{l}<0.1 \\
(0.1) \\
\end{array}$ & $N$ & 0.003 & & & As & . & 0.002 \\
\hline $\mathrm{Nb}$ & $\begin{array}{l}\text { LAP } \\
(0.5 \mathrm{ppm})\end{array}$ & $\overline{\mathrm{Al}}$ & 0.054 & & & $\mathrm{Sb}$ & & 0.003 \\
\hline $\mathrm{N}$ & $\begin{array}{l}<0.001 \\
(0.001)\end{array}$ & $\mathrm{Co}$ & 0.01 & & & $\bar{W}$ & & 0.01 \\
\hline$\overline{\mathrm{Al}}$ & $\begin{array}{l}\text { LAP } \\
(0.02)\end{array}$ & $\mathrm{Cu}$ & 0.015 & & & $\overline{\mathrm{Au}}$ & & 0.00003 \\
\hline & & $\mathrm{Zr}$ & 0.053 & & & $\mathrm{Ta}$ & & 0.08 \\
\hline & & & & & & & & \\
\hline
\end{tabular}


Table A.2 (cont.)

Structural Material Compositions

\begin{tabular}{|c|c|c|c|c|c|c|c|}
\hline \multicolumn{2}{|c|}{$316 \mathrm{SS}^{27}$} & \multicolumn{2}{|c|}{ VA64 $4^{29}$} & \multicolumn{2}{|c|}{$\mathrm{PCA}^{28}$} & \multicolumn{2}{|c|}{ D.S. Copper ${ }^{27}$} \\
\hline \multicolumn{2}{|c|}{$7.86 \mathrm{~g} / \mathrm{cm}^{\wedge} 3$} & \multicolumn{2}{|c|}{$7.72 \mathrm{~g} / \mathrm{cm}^{\wedge} 3$} & \multicolumn{2}{|c|}{$7.97 \mathrm{~g} / \mathrm{cm}^{\wedge} 3$} & \multicolumn{2}{|c|}{$7.97 \mathrm{~g} / \mathrm{cm}^{\wedge} 3$} \\
\hline & $w / o$ & & $w / o$ & & $w / o$ & & \\
\hline $\mathrm{Fe}$ & Remainder & $\mathrm{Fe}$ & Remainder & $\mathrm{Fe}$ & Remainder & $\mathrm{Gu}_{\mathrm{u}}$ & Remainder \\
\hline $\mathrm{Cr}$ & 17.4 & $\mathrm{Cr}$ & 20.76 & $\mathrm{Ni}$ & 16 & $\mathrm{Al}_{2} \mathrm{O}_{3}$ & $0.2 \mathrm{w} / \mathrm{o} \mathrm{Al}$ \\
\hline $\mathrm{Mn}$ & 1.8 & $\mathrm{Ni}$ & 0.25 & $\mathrm{Cr}$ & $\overline{14}$ & impurit & $w / o$ \\
\hline $\mathrm{Ni}$ & 12.3 & $\mathrm{Mn}$ & 10.59 & $\mathrm{Mn}$ & 2 & $\mathrm{Zr}$ & 0.15 \\
\hline Mo & 2.5 & $\mathrm{Si}$ & 0.12 & $\mathrm{Mo}$ & 2 & $\mathrm{Fe}$ & 0.0022 \\
\hline $\mathrm{Co}$ & 0.17 & $\mathrm{~S}$ & 0.006 & $\mathrm{Si}$ & 0.5 & S & 0.0012 \\
\hline $\mathrm{Cu}$ & 0.2 & $\mathrm{P}$ & 0.024 & $\mathrm{Ti}$ & 0.3 & $\mathrm{Ag}$ & 0.0012 \\
\hline$\overline{\mathrm{Si}}$ & 0.46 & $\mathrm{Mo}$ & 1.04 & $\mathrm{~V}$ & 0.1 & $\overline{\mathrm{Ni}}$ & 0.0005 \\
\hline $\mathrm{B}$ & 0.001 & V & 1 & $W$ & 0.05 & As & 0.0005 \\
\hline $\mathrm{C}$ & 0.024 & $\mathrm{~N}$ & 0.5 & $\mathrm{Al}$ & 0.03 & $\mathrm{Sb}$ & 0.0005 \\
\hline $\mathbf{N}$ & 0.06 & C & 0.62 & Co & 0.03 & $\mathrm{~Pb}$ & 0.0005 \\
\hline $\mathrm{S}$ & 0.002 & $\overline{\mathrm{Nb}}$ & 1.2 & $\mathrm{Nb}$ & 0.03 & $\mathrm{Se}$ & 0.0002 \\
\hline $\mathrm{P}$ & 0.027 & Co & 0.03 & $\mathrm{Gu}$ & 0.02 & $\mathrm{sn}$ & 0.0001 \\
\hline & & $\overline{A l}$ & 0.001 & As & 0.02 & $\mathrm{Te}$ & 0.0001 \\
\hline & & Impu & $w / o$ & $\mathbf{N}$ & 0.01 & $\mathrm{Bi}$ & 0.0001 \\
\hline & & Sn & 0.005 & $\mathrm{P}$ & 0.01 & $\mathrm{Mn}$ & 0.00005 \\
\hline & & $\mathrm{Ba}$ & 0.0002 & $\mathrm{Ta}$ & 0.01 & & \\
\hline & & $\mathrm{Sm}$ & 0.00005 & B & 0.005 & & \\
\hline & & $\overline{B i}$ & 0.0005 & C & 0.005 & & \\
\hline & & $\mathrm{Tb}$ & 0.00005 & S & 0.005 & & \\
\hline & & Eu & 0.00002 & $\mathrm{Zr}$ & 0.005 & & \\
\hline & & $\mathrm{Ir}$ & 0.00001 & $\mathrm{Sn}$ & 0.005 & & \\
\hline & & $\overline{A g}$ & 0.00005 & $\mathrm{Sb}$ & 0.001 & & \\
\hline & & & & $\mathrm{Ba}$ & 0.001 & & \\
\hline & & & & $\mathrm{Tb}$ & 0.001 & & \\
\hline & & & & Ir & 0.001 & & \\
\hline & & & & $\mathrm{Pb}$ & 0.001 & & \\
\hline & & & & $\overline{\mathrm{Bi}}$ & 0.001 & & \\
\hline & & & & $\mathrm{K}$ & 0.0003 & & \\
\hline & & & & $\mathrm{Cd}$ & 0.0002 & & \\
\hline & & & & $\mathrm{Ag}$ & 0.0001 & & \\
\hline
\end{tabular}


Table A.3

Breeding Material Compositions

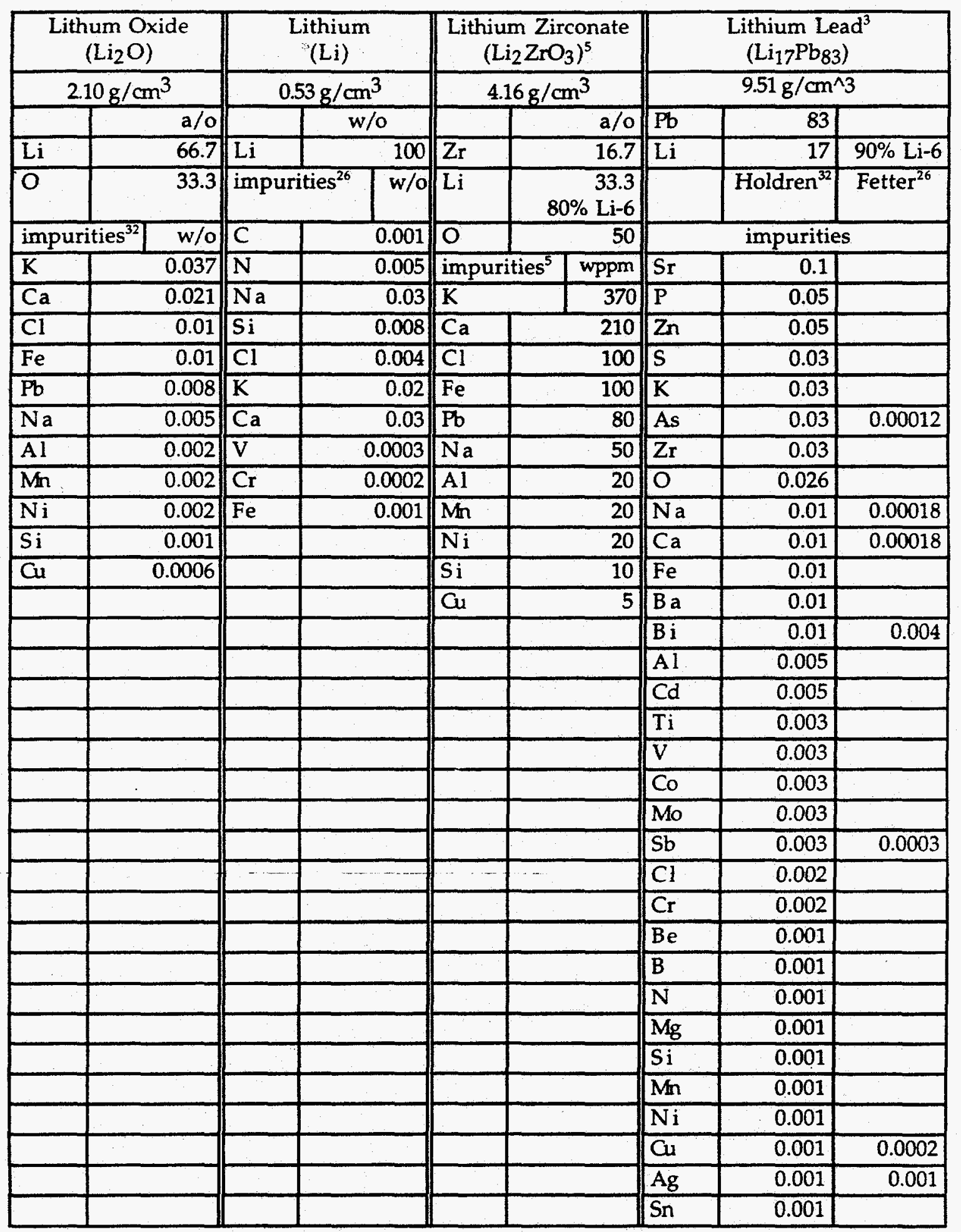


Table A.4

Other Material Compositions

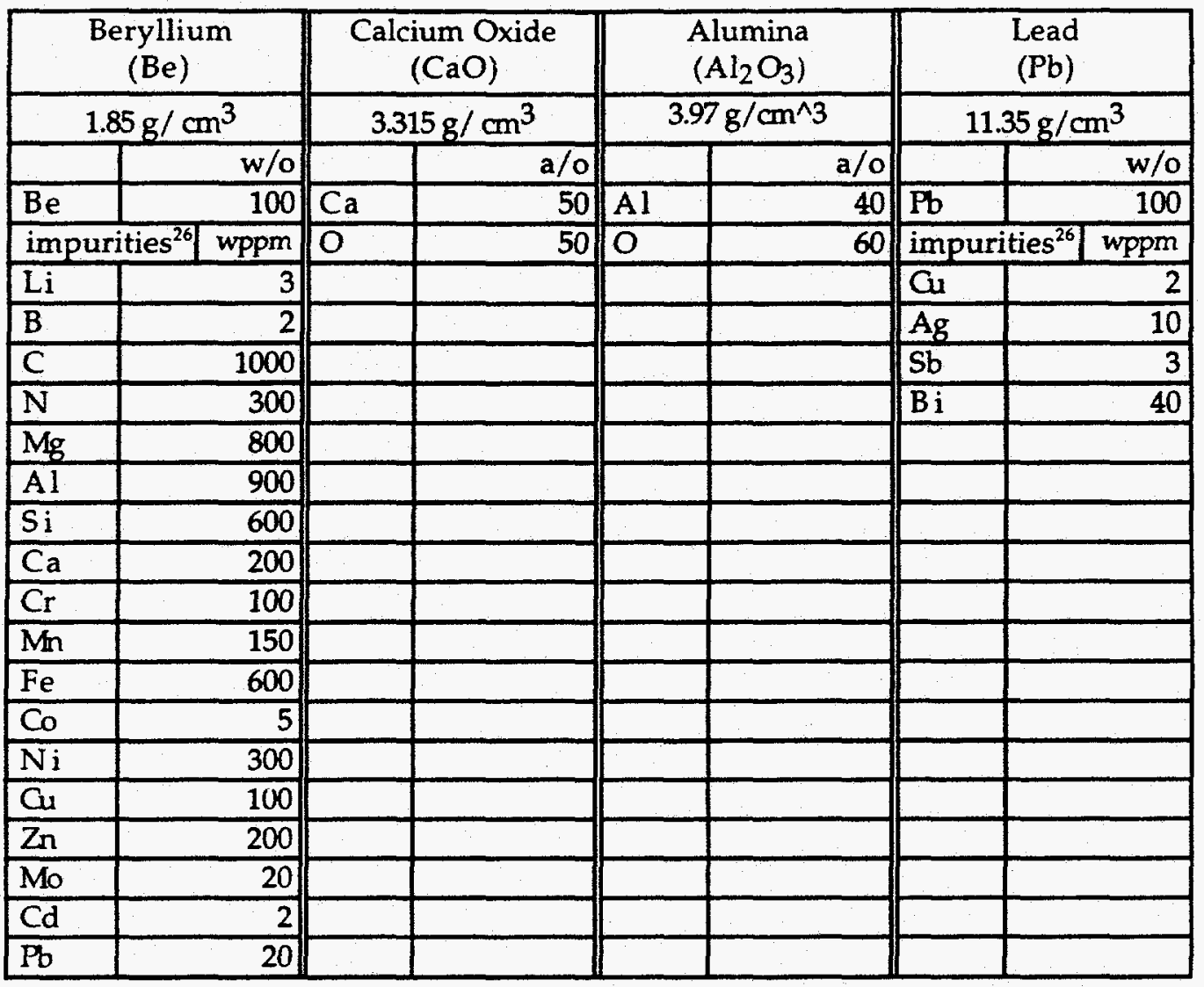


Table B.1

Near-Surface Disposal Specific Activity Limits ${ }^{13}$

\begin{tabular}{|c|c|c|c|c|c|c|c|c|}
\hline Isotope & $\begin{array}{c}\text { Half-life } \\
\text { (yrs) }\end{array}$ & $\begin{array}{c}\text { Limit } \\
\left(\mathrm{Ci} / \mathrm{m}^{\wedge} 3\right)\end{array}$ & Isotope & $\begin{array}{c}\begin{array}{c}\text { Half-life } \\
(y r s)\end{array} \\
\end{array}$ & $\begin{array}{c}\text { Limit } \\
\left(\mathrm{Ci} / \mathrm{m}^{\wedge} 3\right)\end{array}$ & Isotope & $\begin{array}{c}\begin{array}{c}\text { Half-life } \\
\text { (yrs) }\end{array} \\
\end{array}$ & $\begin{array}{c}\text { Limit } \\
\left(\mathrm{Ci} / \mathrm{m}^{\wedge} 3\right) \\
\end{array}$ \\
\hline h 3 & $1.23 E+01$ & $\mathrm{TMSA}^{\mathrm{T}}$ & $\mathrm{sn} 121 \mathrm{~m}$ & $5.50 \mathrm{E}+01$ & $7.00 \mathrm{E}+05$ & $\mathrm{pb} 210$ & $2.23 \mathrm{E}+01$ & $3.00 \mathrm{E}+07$ \\
\hline be 10 & $1.60 \mathrm{E}+06$ & $5.00 \mathrm{E}+03$ & $\operatorname{sn} 126$ & $1.00 \mathrm{E}+05$ & $1.00 \mathrm{E}-01$ & bi207 & $3.22 \mathrm{E}+01$ & $9.00 \mathrm{E}+03$ \\
\hline c 14 & $5.70 \mathrm{E}+03$ & $6.00 \mathrm{E}+02$ & i129 & $1.57 \mathrm{E}+07$ & $2.00 \mathrm{E}+00$ & bi210m & $3.00 \mathrm{E}+06$ & $1.00 \mathrm{E}+00$ \\
\hline al 26 & $7.20 \mathrm{E}+05$ & $9.00 \mathrm{E}-02$ & $\operatorname{cs135}$ & $3.00 \mathrm{E}+06$ & $1.70 \mathrm{E}+03$ & po209 & $1.02 \mathrm{E}+02$ & $3.00 \mathrm{E}+03$ \\
\hline si 32 & $1.04 \mathrm{E}+02$ & $6.00 \mathrm{E}+02$ & cs137 & $3.00 \mathrm{E}+01$ & $5.00 \mathrm{E}+04$ & ra226 & $1.60 \mathrm{E}+03$ & $1.00 \mathrm{E}-01$ \\
\hline $\mathrm{cl} 36$ & $3.01 \mathrm{E}+02$ & $1.00 \mathrm{E}+01$ & la137 & $6.00 \mathrm{E}+04$ & $2.00 \mathrm{E}+02$ & $\mathrm{ra228}$ & $5.80 \mathrm{E}+06$ & $3.00 \mathrm{E}+07$ \\
\hline ar 39 & $2.69 \mathrm{E}+02$ & $2.00 \mathrm{E}+04$ & la138 & $1.06 \mathrm{E}+11$ & $1.50 \mathrm{E}-01$ & ac227 & $2.18 \mathrm{E}+01$ & $5.00 \mathrm{E}+05$ \\
\hline $\operatorname{ar} 42$ & $3.30 \mathrm{E}+01$ & $2.00 \mathrm{E}+04$ & $\mathrm{pm} 145$ & $1.77 \mathrm{E}+01$ & $1.00 \mathrm{E}+09$ & $\operatorname{th} 229$ & $7.30 \mathrm{E}+03$ & $2.00 \mathrm{E}+00$ \\
\hline k 40 & $1.30 \mathrm{E}+09$ & $2.00 \mathrm{E}+00$ & $\mathrm{pm} 146$ & $5.50 \mathrm{E}+00$ & $3.20 \mathrm{E}+09$ & th 230 & $7.40 \mathrm{E}+04$ & $3.00 \mathrm{E}-01$ \\
\hline ca 41 & $1.03 E+05$ & $1.00 \mathrm{E}+04$ & $\operatorname{sm} 146$ & $1.03 \mathrm{E}+06$ & $1.70 \mathrm{E}+02$ & th 232 & $1.40 \mathrm{E}+10$ & $1.00 \mathrm{E}-01$ \\
\hline ti 44 & $4.70 \mathrm{E}+01$ & $2.00 \mathrm{E}+02$ & $\operatorname{sm} 147$ & $1.06 \mathrm{E}+11$ & $1.70 \mathrm{E}-01$ & pa231 & $6.28 \mathrm{E}+04$ & $7.00 \mathrm{E}-01$ \\
\hline $\mathrm{mn} 53$ & TMSA $^{1}$ & $1.30 \mathrm{E}+04$ & sm151 & $9.00 \mathrm{E}+01$ & $5.00 \mathrm{E}+07$ & u 232 & $6.89 \mathrm{E}+01$ & $3.00 \mathrm{E}+01$ \\
\hline fe 60 & $1.00 \mathrm{E}+05$ & $1.00 \mathrm{E}-01$ & eu150m & $3.60 \mathrm{E}+01$ & $3.00 \mathrm{E}+03$ & u 233 & $1.59 \mathrm{E}+05$ & $2.00 \mathrm{E}+01$ \\
\hline $\cos 60$ & $5.30 \mathrm{E}+00$ & $3.00 \mathrm{E}+08$ & eu152 & $1.33 \mathrm{E}+01$ & $3.00 \mathrm{E}+05$ & u 234 & $2.45 \mathrm{E}+05$ & $9.00 \mathrm{E}+01$ \\
\hline nं 59 & $7.50 \mathrm{E}+05$ & $9.00 \mathrm{E}+02$ & eu154 & $8.80 \mathrm{E}+00$ & $5.00 \mathrm{E}+06$ & บ 235 & $7.04 E+08$ & $2.00 \mathrm{E}+00$ \\
\hline ni 63 & $1.00 \mathrm{E}+02$ & $7.00 \mathrm{E}+05$ & gd148 & $9.80 \mathrm{E}+01$ & $2.00 \mathrm{E}+05$ & u 236 & TMSA $^{1}$ & $1.20 \mathrm{E}+03$ \\
\hline se 79 & $6.50 \mathrm{E}+05$ & $5.00 \mathrm{E}+01$ & gd150 & $1.80 \mathrm{E}+06$ & $2.00 \mathrm{E}+03$ & u 238 & TMSA $^{1}$ & $6.30 \mathrm{E}+00$ \\
\hline $\mathrm{kr} 81$ & $2.10 \mathrm{E}+05$ & $3.00 \mathrm{E}+01$ & tb157 & $1.50 \mathrm{E}+02$ & $5.00 \mathrm{E}+03$ & $n p 236$ & $1.15 \mathrm{E}+05$ & $1.00 \mathrm{E}+00$ \\
\hline $\mathrm{kr} 85$ & TMSA $^{1}$ & $6.00 \mathrm{E}+08$ & tb158 & $1.50 \mathrm{E}+02$ & $4.00 \mathrm{E}+00$ & np237 & $2.10 \mathrm{E}+06$ & $1.00 \mathrm{E}+00$ \\
\hline $\mathrm{rb} 87$ & TMSA $^{1}$ & $1.30 \mathrm{E}-01$ & dy154 & $1.00 \mathrm{E}+07$ & $1.00 \bar{E}+03$ & pu238 & $8.77 \mathrm{E}+01$ & $7.00 \mathrm{E}+04$ \\
\hline sr 90 & $2.85 E+01$ & $8.00 E+05$ & ho166m & $1.20 \mathrm{E}+03$ & $2.00 \mathrm{E}-01$ & pu239 & $2.41 E+04$ & $1.00 \mathrm{E}+03$ \\
\hline$\overline{\text { zr } 93}$ & TMSA $^{\top}$ & $1.70 E+04$ & lu176 & $\overline{T M S A}^{T}$ & $5.60 \mathrm{E}-01$ & pu240 & $6.60 \mathrm{E}+03$ & $1.00 \mathrm{E}+03$ \\
\hline nb 91 & $6.80 \mathrm{E}+02$ & $2.00 \mathrm{E}+02$ & hf178m & $3.10 \mathrm{E}+01$ & $9.00 \mathrm{E}+03$ & pu241 & $1.44 \mathrm{E}+01$ & $2.00 \mathrm{E}+03$ \\
\hline nb 92 & $3.60 \mathrm{E}+07$ & $2.00 \mathrm{E}-01$ & hf182 & $9.00 \mathrm{E}+06$ & $2.00 \mathrm{E}-01$ & pu242 & $3.73 E+05$ & $1.00 \mathrm{E}+03$ \\
\hline$n b 93 m$ & TMSA $^{1}$ & $2.40 E+03$ & $\mathrm{re} 186 \mathrm{~m}$ & $2.00 \mathrm{E}+05$ & $2.00 \mathrm{E}+01$ & pu244 & $8.08 \mathrm{E}+07$ & $9.00 \mathrm{E}-01$ \\
\hline nb 94 & $2.00 \mathrm{E}+04$ & $2.00 \mathrm{E}-01$ & re187 & TMSA $^{1}$ & $1.00 \mathrm{E}+00$ & $\operatorname{am} 241$ & $4.32 \mathrm{E}+02$ & $5.00 \mathrm{E}+01$ \\
\hline $\operatorname{mo} 93$ & $3.50 \mathrm{E}+03$ & $4.00 \mathrm{E}+03$ & os194 & $\mathrm{TMSA}^{1}$ & $7.10 E+09$ & $\operatorname{am} 242 m$ & $1.41 \mathrm{E}+02$ & $3.00 \mathrm{E}+02$ \\
\hline tc 97 & $2.60 E+06$ & $4.00 \mathrm{E}-01$ & ir192m & $2.41 \mathrm{E}+02$ & $1.00 E+00$ & $\operatorname{am} 243$ & $7.40 \mathrm{E}+03$ & $2.00 \mathrm{E}+00$ \\
\hline tc 98 & $4.20 \mathrm{E}+06$ & $1.00 \mathrm{E}-02$ & pt190 & $\mathrm{TMSA}^{1}$ & $6.50 \mathrm{E}-02$ & $\mathrm{~cm} 243$ & $2.85 \mathrm{E}+01$ & $6.00 \mathrm{E}+02$ \\
\hline tc 99 & $2.13 E+05$ & $6.00 \mathrm{E}-02$ & $p+193$ & $5.00 \mathrm{E}+01$ & $2.00 \mathrm{E}+08$ & $\mathrm{~cm} 244$ & $1.81 E+01$ & $5.00 \mathrm{E}+05$ \\
\hline pd107 & $6.50 \mathrm{E}+06$ & $9.00 \mathrm{E}+02$ & hg194 & $5.20 \mathrm{E}+02$ & $5.00 \mathrm{E}-01$ & $\mathrm{~cm} 245$ & $8.50 \mathrm{E}+03$ & $5.00 \mathrm{E}+00$ \\
\hline ag108m & $1.27 \mathrm{E}+02$ & $3.00 \mathrm{E}+\infty 0$ & pb202 & $5.30 \mathrm{E}+04$ & $6.00 \mathrm{E}-01$ & $\mathrm{~cm} 246$ & $4.80 \mathrm{E}+03$ & $8.00 \mathrm{E}+02$ \\
\hline $\mathrm{cd} 113 \mathrm{~m}$ & $\mathrm{TMSA}^{1}$ & $2.00 \mathrm{E}+09$ & pb205 & TMSA $^{1}$ & $1.00 \mathrm{E}+03$ & $\mathrm{~cm} 248$ & $3.40 \mathrm{E}+05$ & $8.00 \mathrm{E}+02$ \\
\hline
\end{tabular}

1. Theoretical Maximum Specific Activity (TMSA) does not exceed dose limits to inadvertent intruder. 
Table C.1

Dominant Element Contributions to the Waste Disposal Rating

\begin{tabular}{|c|c|c|c|c|c|c|}
\hline & $\begin{array}{l}\text { First } \\
\text { Wall }\end{array}$ & $\begin{array}{c}\text { Divertor } \\
\text { Plate }\end{array}$ & $\begin{array}{c}\text { Divertor } \\
\text { Wall }\end{array}$ & Blanket & $\begin{array}{l}\text { Vacuum } \\
\text { Vessel }\end{array}$ & Shield \\
\hline \multicolumn{7}{|c|}{ Reference $\mathrm{FeS} / \mathrm{Li}_{2} \mathrm{O} / \mathrm{H}_{2} \mathrm{O}$ Design (R1) } \\
\hline \multicolumn{7}{|c|}{ Structure by Element } \\
\hline $\bar{W}$ & $3.82 \mathrm{E}-01$ & & $5.38 \mathrm{E}-01$ & $1.32 \mathrm{E}-02$ & $8.65 \mathrm{E}-03$ & $7.80 \mathrm{E}-04$ \\
\hline Mo & $* 7.91 \mathrm{E}-02$ & & $* 1.04 \mathrm{E}-01$ & $7.31 \mathrm{E}-03$ & $* 9.48 \mathrm{E}-03$ & $* 8.39 \mathrm{E}-04$ \\
\hline $\mathbf{N b}$ & $* 1.33 \mathrm{E}-01$ & & * 1.79E-01 & $* 1.49 \mathrm{E}-02$ & $* 2.17 \mathrm{E}-02$ & * $1.93 \mathrm{E}-03$ \\
\hline Al & $* 2.58 \mathrm{E}-01$ & $1.08 \mathrm{E}+00$ & * 3.70E-01 & $* 6.06 \mathrm{E}-03$ & * $2.67 \mathrm{E}-03$ & $2.25 \mathrm{E}-04$ \\
\hline $\mathrm{Ag}$ & & $75.92 \mathrm{E}+00$ & & & & \\
\hline $\mathrm{Gu}_{\mathrm{u}}$ & & $3.90 \mathrm{E}-01$ & & & & \\
\hline \multicolumn{7}{|l|}{ Other } \\
\hline $\mathrm{Li}_{2} \mathrm{O}(w / i m p)$ & & & & 7.00E-02 & & \\
\hline $\mathrm{Al}_{2} \mathrm{O}_{3}$ & & & & $3.54 \mathrm{E}+00$ & & \\
\hline $\mathrm{Be}(\mathrm{w} / \mathrm{imp})$ & & & & 5.75E-02 & & \\
\hline $\mathrm{Pb}(\mathrm{w} / \mathrm{imp})$ & & & & & & $6.27 \mathrm{E}-05$ \\
\hline \multicolumn{7}{|c|}{ Reference MS $/ \mathrm{Li}_{17} \mathrm{~Pb}_{83} / \mathrm{H}_{2} \mathrm{O}$ Design (R2) } \\
\hline \multicolumn{7}{|c|}{ Structure by Element } \\
\hline Mo & $1.49 \mathrm{E}+02$ & & $2.12 \mathrm{E}+02$ & $5.34 \mathrm{E}+01$ & $3.54 \mathrm{E}+01$ & $3.76 \mathrm{E}+00$ \\
\hline$\overline{\mathrm{Nb}}$ & $4.24 \mathrm{E}+02$ & & $6.10 \mathrm{E}+02$ & $1.96 \mathrm{E}+02$ & $1.38 \mathrm{E}+02$ & $1.52 \mathrm{E}+01$ \\
\hline$\overline{\mathrm{Al}}$ & & $1.20 \mathrm{E}+00$ & & & & \\
\hline$\overline{\mathrm{Ag}}$ & & $* 5.43 \mathrm{E}+00$ & & & & \\
\hline$\overline{G u}$ & & $4.10 \mathrm{E}-01$ & & & & \\
\hline \multicolumn{7}{|l|}{ Other } \\
\hline $\mathrm{Pb}(\mathrm{w} / \mathrm{imp})$ & & & & & & $1.22 \mathrm{E}-04$ \\
\hline $\mathrm{Li}_{17} \mathrm{~Pb}_{83}$ & & & & $6.64 \mathrm{E}-02$ & & \\
\hline Mo & & & & ** 3.46E-01 & & \\
\hline$\overline{\mathrm{Ag}}$ & & & & $7 * 3.56 \mathrm{E}+00$ & & \\
\hline \multirow{2}{*}{\multicolumn{7}{|c|}{ Reference V/Li Design (R3) }} \\
\hline \multicolumn{6}{|c|}{ Structure by Element } & \\
\hline$\overline{S i}$ & $1.80 \mathrm{E}-03$ & & $3.44 \mathrm{E}-03$ & $1.53 \mathrm{E}-05$ & & \\
\hline $\mathrm{Nb}$ & * 1.93E-01 & & 2.64E-01 & * 2.13E-02 & *2.16E-02 & * $1.12 \mathrm{E}-03$ \\
\hline Al & & $1.11 \mathrm{E}+00$ & & & & \\
\hline$\overline{\mathrm{Ag}}$ & & * $3.15 E+00$ & & & & \\
\hline $\bar{W}$ & & & & & $\begin{array}{l}7.06 \mathrm{E}-03 \\
\end{array}$ & $\begin{array}{l}3.17 \mathrm{E}-04 \\
\end{array}$ \\
\hline Mo & & & & & $9.84 \mathrm{E}-03$ & $4.74 \mathrm{E}-04$ \\
\hline$\overline{\mathrm{Cu}}$ & & $3.70 \mathrm{E}-01$ & & & & \\
\hline \multicolumn{7}{|l|}{ Other } \\
\hline $\mathrm{CaO}$ & & & & 5.86E-02 & & \\
\hline $\mathrm{Pb}(\mathrm{w} / \mathrm{imp})$ & & & & & & $5.52 \mathrm{E}-05$ \\
\hline $\mathrm{Li}$ & & & & $6.01 \mathrm{E}-02$ & & \\
\hline $\mathrm{K}$ & & & & $* * \quad 1.04 \mathrm{E}-03$ & & \\
\hline $\mathbf{N}$ & & & & $* \quad 5.49 \mathrm{E}-04$ & & \\
\hline
\end{tabular}


Table C.1 (cont.)

Dominant Element Contributions to the

Waste Disposal Rating

\begin{tabular}{|c|c|c|c|c|c|c|}
\hline & $\begin{array}{l}\text { First } \\
\text { Wall }\end{array}$ & $\begin{array}{c}\text { Divertor } \\
\text { Plate }\end{array}$ & $\begin{array}{c}\text { Divertor } \\
\text { Wall } \\
\end{array}$ & Blanket & $\begin{array}{c}\text { Vacuum } \\
\text { Vessel }\end{array}$ & Shield \\
\hline \multicolumn{7}{|c|}{ Reference $\mathrm{SiC} / \mathrm{Li}_{2} \mathrm{ZrO}_{3} / \mathrm{He}$ Design (R4) } \\
\hline \multicolumn{7}{|c|}{ Structure by Element } \\
\hline$S i$ & $1.59 \mathrm{E}+00$ & & $2.71 \mathrm{E}+00$ & $1.52 \mathrm{E}-02$ & & \\
\hline C & $2.77 \mathrm{E}-04$ & & $3.62 \mathrm{E}-04$ & $3.86 \mathrm{E}-04$ & & \\
\hline $\mathrm{Al}$ & & $1.14 \mathrm{E}+00$ & & & & \\
\hline$\overline{\mathrm{Ag}}$ & & $4.79 \mathrm{E}+00$ & & & & \\
\hline $\mathrm{W}$ & & & & & $7.60 \mathrm{E}-03$ & $9.69 \mathrm{E}-05$ \\
\hline Mo & & & & & $* 4.39 \mathrm{E}-03$ & * 1.91E-04 \\
\hline $\mathrm{Nb}$ & & & & & *1.18E-02 & * 5.02E-04 \\
\hline $\mathrm{Cu}$ & & $4.10 \mathrm{E}-01$ & & & & \\
\hline \multicolumn{7}{|l|}{ Other } \\
\hline $\operatorname{Be}(w / i m p)$ & & & & $4.27 \mathrm{E}-02$ & & \\
\hline $\begin{array}{l}\mathrm{Li}_{2} \mathrm{ZrO}_{3} \\
(w / \mathrm{imp})\end{array}$ & & & & $2.27 \mathrm{E}-02$ & & \\
\hline $\mathrm{Pb}(\mathrm{w} / \mathrm{imp})$ & & & & & & $6.71 \mathrm{E}-05$ \\
\hline \multicolumn{7}{|c|}{ Variant $\mathrm{V} / \mathrm{Li}_{2} \mathrm{O} / \mathrm{H}_{2} \mathrm{O}$ Design (V1) } \\
\hline \multicolumn{7}{|c|}{ Structure by Element } \\
\hline $\mathrm{Nb}$ & *2.00E-01 & & * $2.73 \mathrm{E}-01$ & * $3.32 \mathrm{E}-02$ & * 5.30E-02 & * 4.36E-03 \\
\hline $\mathrm{Si}$ & $1.71 \mathrm{E}-03$ & & $3.76 \mathrm{E}-03$ & $1.41 \mathrm{E}-05$ & & \\
\hline A1 & & $1.17 \mathrm{E}+00$ & & & & \\
\hline $\mathrm{Ag}$ & & ${ }^{*} 6.37 \mathrm{E}+00$ & & & & \\
\hline $\bar{W}$ & & & & & $5.19 \mathrm{E}-02$ & $3.87 \mathrm{E}-03$ \\
\hline Mo & & & & & $2.67 \mathrm{E}-02$ & * $1.95 \mathrm{E}-03$ \\
\hline $\mathrm{Gu}$ & & $4.20 \mathrm{E}-01$ & & & & \\
\hline \multicolumn{7}{|l|}{ Other } \\
\hline $\mathrm{Li}_{2} \mathrm{O}(\mathrm{w} / \mathrm{imp})$ & & & & $8.63 \mathrm{E}-02$ & & \\
\hline $\operatorname{Be}(w / i m p)$ & & & & $7.59 \mathrm{E}-02$ & & \\
\hline $\mathrm{Pb}(\mathrm{w} / \mathrm{imp})$ & & & & & & $1.23 \mathrm{E}-04$ \\
\hline \multicolumn{7}{|c|}{ Variant $316 \mathrm{SS} / \mathrm{Li}_{2} \mathrm{O} / \mathrm{H}_{2} \mathrm{O}$ Design (V2) } \\
\hline Mo & $1.47 \mathrm{E}+02$ & & $2.79 \mathrm{E}+02$ & $1.39 \mathrm{E}+01$ & $3.55 \mathrm{E}+01$ & $2.93 \mathrm{E}+00$ \\
\hline $\mathrm{Al}$ & & $1.02 \mathrm{E}+00$ & & & & \\
\hline $\mathrm{Ag}$ & & $6.05 \mathrm{E}+0 \mathrm{~g}$ & & & & \\
\hline $\mathrm{Gu}$ & & $3.70 \mathrm{E}-01$ & & & & \\
\hline \multicolumn{7}{|l|}{ Other } \\
\hline $\mathrm{Li}_{2} \mathrm{O}(w / \mathrm{imp})$ & & & & $2.81 \mathrm{E}-02$ & & \\
\hline $\operatorname{Be}(w / i m p)$ & & & & $1.74 \mathrm{E}-02$ & & \\
\hline $\mathrm{Pb}(w / \mathrm{imp})$ & & & & & & $6.15 E-05$ \\
\hline
\end{tabular}

* Structural Impurity 
Table C.1 (cont.)

Dominant Element Contributions to the

Waste Disposal Rating

\begin{tabular}{|c|c|c|c|c|c|c|}
\hline & $\begin{array}{l}\text { First } \\
\text { Wall }\end{array}$ & $\begin{array}{c}\text { Divertor } \\
\text { Plate }\end{array}$ & $\begin{array}{c}\text { Divertor } \\
\text { Wall }\end{array}$ & Blanket & $\begin{array}{c}\text { Vacuum } \\
\text { Vessel }\end{array}$ & Shield \\
\hline \multicolumn{7}{|c|}{ Variant $\mathrm{PCA} / \mathrm{Li}_{2} \mathrm{O} / \mathrm{H}_{2} \mathrm{O}$ Design (V3) } \\
\hline \multicolumn{7}{|c|}{ Structure by Element } \\
\hline Mo & $2.10 E+02$ & & $3.18 \mathrm{E}+02$ & $2.20 \mathrm{E}+01$ & $4.11 E+01$ & $3.53 E+00$ \\
\hline $\mathrm{Al}$ & 1.73E-01 & $5.98 \mathrm{E}-01$ & $2.83 E-01$ & $4.61 \mathrm{E}-03$ & $4.12 \mathrm{E}-03$ & $3.26 \mathrm{E}-04$ \\
\hline$\overline{\mathrm{Nb}}$ & $4.18 \mathrm{E}+01$ & & $6.48 E+01$ & $5.29 \mathrm{E}+00$ & $1.05 \mathrm{E}+01$ & $9.45 \mathrm{E}-01$ \\
\hline$\overline{\mathrm{Ag}}$ & & * $3.82 \mathrm{E}+00$ & & & & \\
\hline $\mathrm{Gu}$ & & $2.09 \mathrm{E}-01$ & & & & \\
\hline \multicolumn{7}{|l|}{ Other } \\
\hline $\mathrm{Li}_{2} \mathrm{O}(\mathrm{w} / \mathrm{imp})$ & & & & $4.60 E-02$ & & \\
\hline $\mathrm{Be}(\mathrm{w} / \mathrm{imp})$ & & & & $4.10 \mathrm{E}-02$ & & \\
\hline $\mathrm{Pb}(\mathrm{w} / \mathrm{imp})$ & & & & & & $6.26 \mathrm{E}-05$ \\
\hline \multicolumn{7}{|c|}{ Variant VA64/ $\mathrm{Li}_{2} \mathrm{O} / \mathrm{H}_{2} \mathrm{O}$ Design (V4) } \\
\hline \multicolumn{7}{|c|}{ Structure by Element } \\
\hline Mo & $7.28 \mathrm{E}+01$ & & $1.09 E+02$ & $5.68 \mathrm{E}+00$ & $2.75 E+01$ & $2.52 \mathrm{E}+00$ \\
\hline $\mathrm{Nb}$ & $9.73 \mathrm{E}+02$ & & $1.48 E+03$ & $1.01 E+02$ & $5.26 \mathrm{E}+02$ & $5.02 \mathrm{E}+01$ \\
\hline $\mathrm{Al}$ & & $1.26 \mathrm{E}+0 \mathrm{~g}$ & & & & \\
\hline$\overline{\mathrm{Ag}}$ & & * $6.14 \mathrm{E}+0 \mathrm{O}$ & & & & \\
\hline $\mathrm{Cu}$ & & $4.48 \mathrm{E}-01$ & & & & \\
\hline \multicolumn{7}{|l|}{\begin{tabular}{|l|} 
Other \\
\end{tabular}} \\
\hline $\mathrm{Li}_{2} \mathrm{O}(\mathrm{w} / \mathrm{imp})$ & & & & $2.97 \mathrm{E}-02$ & & \\
\hline $\mathrm{Be}(w / \mathrm{imp})$ & & & & $1.81 \mathrm{E}-02$ & & \\
\hline $\mathrm{Pb}(\mathrm{w} / \mathrm{imp})$ & & & & & & $6.69 \mathrm{E}-05$ \\
\hline
\end{tabular}

* Structural Impurity 
Table D.1

Maximum Impurity Concentrations

\begin{tabular}{|l|r|r|}
\hline \multicolumn{3}{|c|}{$\mathrm{Li}_{17} \mathrm{~Pb}_{83}-$ Blanket (R2) } \\
\hline $\mathrm{Ag}$ & $2.6 \mathrm{ppm}$ & \\
\hline $\mathrm{Mo}$ & $81 \mathrm{ppm}$ & \\
\hline & $\begin{array}{c}\text { First } \\
\text { Wall }\end{array}$ & $\begin{array}{c}\text { Divertor } \\
\text { Wall }\end{array}$ \\
\hline \multicolumn{3}{|c|}{ Ferritic Steel (R1) } \\
\hline $\mathrm{Mo}$ & $31 \mathrm{ppm}$ & $18 \mathrm{ppm}$ \\
\hline $\mathrm{Nb}$ & $2.3 \mathrm{ppm}$ & $1.3 \mathrm{ppm}$ \\
\hline $\mathrm{Al}$ & $0.048 \%$ & $0.025 \%$ \\
\hline \multicolumn{3}{|c|}{ Vanadium (R3) } \\
\hline $\mathrm{Mo}$ & $97 \mathrm{ppm}$ & $71 \mathrm{ppm}$ \\
\hline $\mathrm{Nb}$ & $5.2 \mathrm{ppm}$ & $3.8 \mathrm{ppm}$ \\
\hline $\mathrm{Si}$ & \multicolumn{3}{|c|}{$28 \%$} & $15 \%$ \\
\hline \multicolumn{3}{|c|}{ Vanadium (V1) } \\
\hline $\mathrm{Mo}$ & $98 \mathrm{ppm}$ & $73 \mathrm{ppm}$ \\
\hline $\mathrm{Nb}$ & $5.0 \mathrm{ppm}$ & $3.7 \mathrm{ppm}$ \\
\hline $\mathrm{Si}$ & $29 \%$ & $13 \%$ \\
\hline
\end{tabular}




\section{List of Figures}

1. Comparison of First Wall Waste Disposal Ratings

2. Comparison of Divertor Wall Waste Disposal Ratings

3. Comparison of Blanket Waste Disposal Ratings

4. Comparison of Vacuum Vessel Waste Disposal Ratings

5. Comparison of Shield Waste Disposal Ratings

6. Comparison of Deep Disposal Indexes

7. Comparison of First Wall Specific Activities (10 Years After Shutdown)

8. Comparison of First Wall Contact Doses (10 Years After Shutdown)

9. Comparison of Life Cycle Volumes

D.1. Waste Disposal Rating Reference $\mathrm{FeS} / \mathrm{Li}_{2} \mathrm{O} / \mathrm{H}_{2} \mathrm{O}$ Blanket Design (R1)

D.2. Specific Activity Reference $\mathrm{FeS} / \mathrm{Li}_{2} \mathrm{O} / \mathrm{H}_{2} \mathrm{O}$ Blanket Design (R1)

D.3. Contact Dose Reference FeS $/ \mathrm{Li}_{2} \mathrm{O} / \mathrm{H}_{2} \mathrm{O}$ Blanket Design (R1)

D.4. Waste Disposal Rating Reference MS/ $\mathrm{Li}_{17} \mathrm{~Pb}_{83} / \mathrm{H}_{2} \mathrm{O}$ Blanket Design (R2)

D.5. Specific Activity Reference MS $/ \mathrm{Li}_{17} \mathrm{~Pb}_{83} / \mathrm{H}_{2} \mathrm{O}$ Blanket Design (R2)

D.6. Contact Dose Reference $\mathrm{MS} / \mathrm{Li}_{17} \mathrm{~Pb}_{83} / \mathrm{H}_{2} \mathrm{O}$ Blanket Design (R2)

D.7. Waste Disposal Rating ReferenceV/Li Blanket Design (R3)

D.8. Specific Activity Reference V/Li Blanket Design (R3)

D.9. Contact Dose Reference V/Li Blanket Design (R3)

D.10. Waste Disposal Rating Reference $\mathrm{SiC} / \mathrm{Li}_{2} \mathrm{ZrO}_{3} / \mathrm{He}$ Blanket Design (R4)

D.11. Specific Activity Reference $\mathrm{SiC} / \mathrm{Li}_{2} \mathrm{ZrO}_{3} / \mathrm{He}$ Blanket Design (R4)

D.12. Contact Dose Reference $\mathrm{SiC} / \mathrm{Li}_{2} \mathrm{ZrO}_{3} / \mathrm{He}$ Blanket Design (R4)

D.13. Waste Disposal Rating Reference $\mathrm{V} / \mathrm{Li}_{2} \mathrm{O} / \mathrm{H}_{2} \mathrm{O}$ Blanket Design (V1)

D.14. Specific Activity Reference $\mathrm{V} / \mathrm{Li}_{2} \mathrm{O} / \mathrm{H}_{2} \mathrm{O}$ Blanket Design (V1)

D.15. Contact Dose Reference $\mathrm{V} / \mathrm{Li}_{2} \mathrm{O} / \mathrm{H}_{2} \mathrm{O}$ Blanket Design (V1)

D.16. Waste Disposal Rating Reference $316 \mathrm{SS} / \mathrm{Li}_{2} \mathrm{O} / \mathrm{H}_{2} \mathrm{O}$ Blanket Design (V2)

D.17. Specific Activity Reference $316 \mathrm{SS} / \mathrm{Li}_{2} \mathrm{O} / \mathrm{H}_{2} \mathrm{O}$ Blanket Design (V2)

D.18. Contact Dose Reference 316SS $/ \mathrm{Li}_{2} \mathrm{O} / \mathrm{H}_{2} \mathrm{O}$ Blanket Design (V2) 


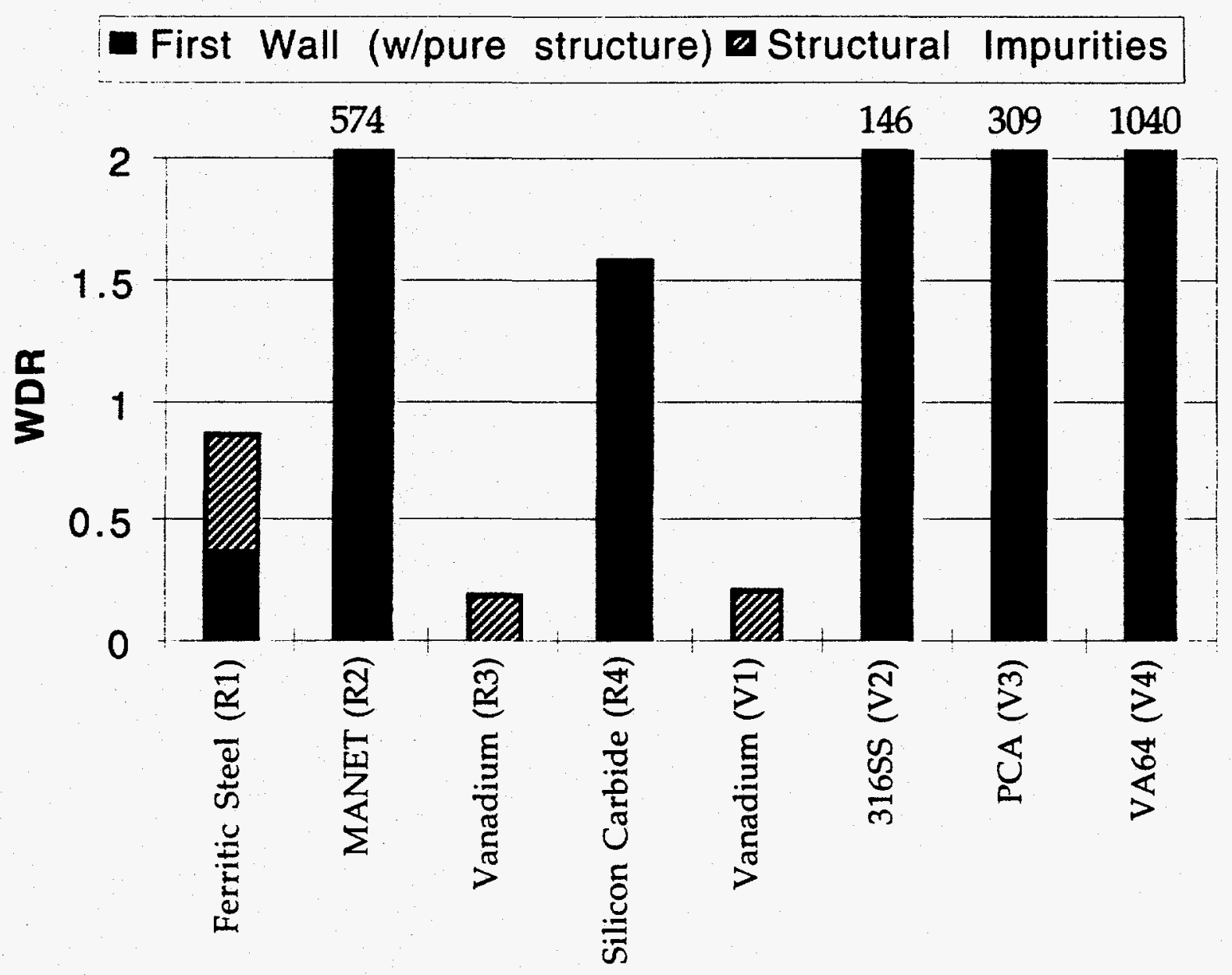

Figure 1

Comparison of First Wall Waste Disposal Ratings 


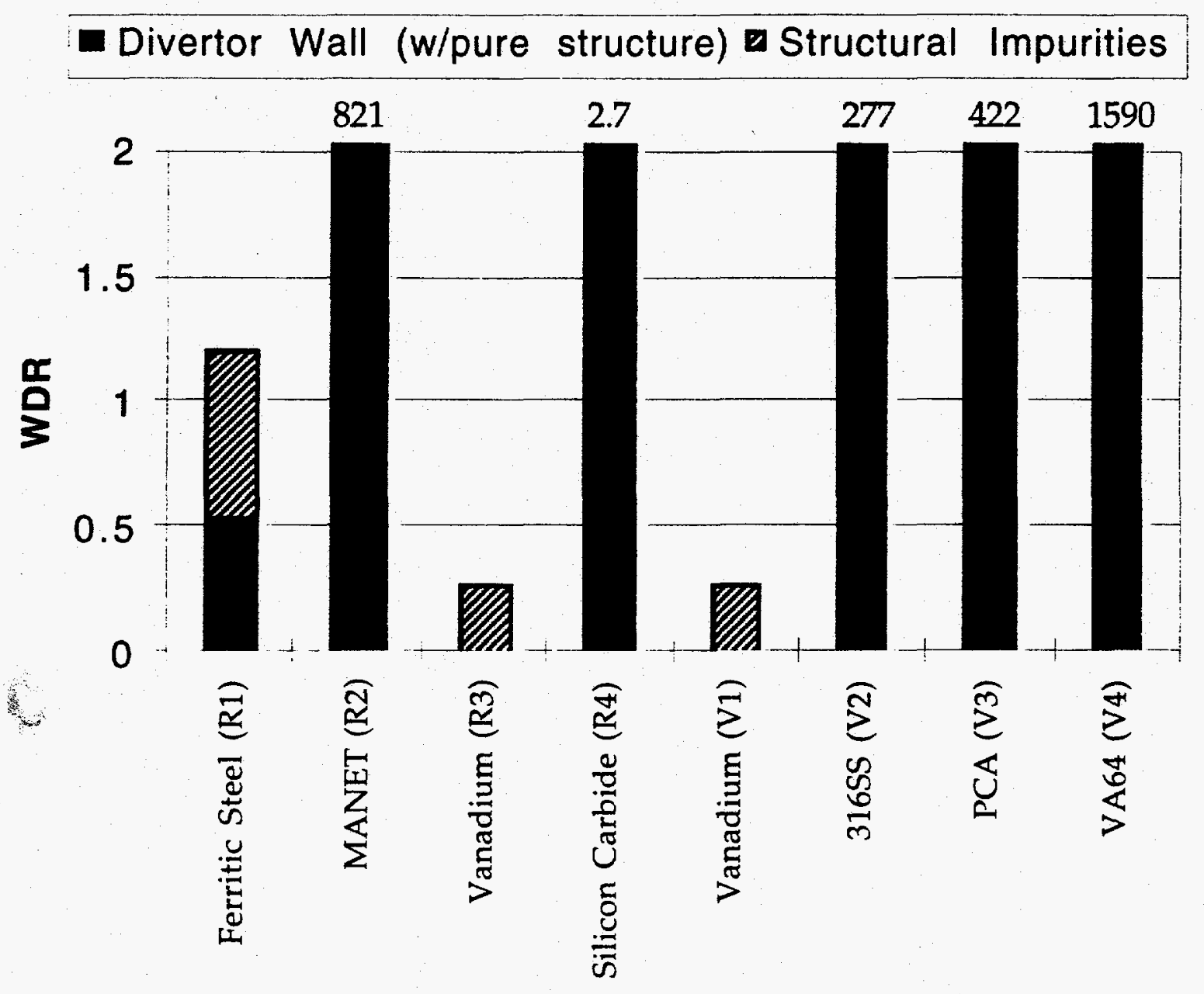

Figure 2

Comparison of Divertor Wall Waste Disposal Ratings 


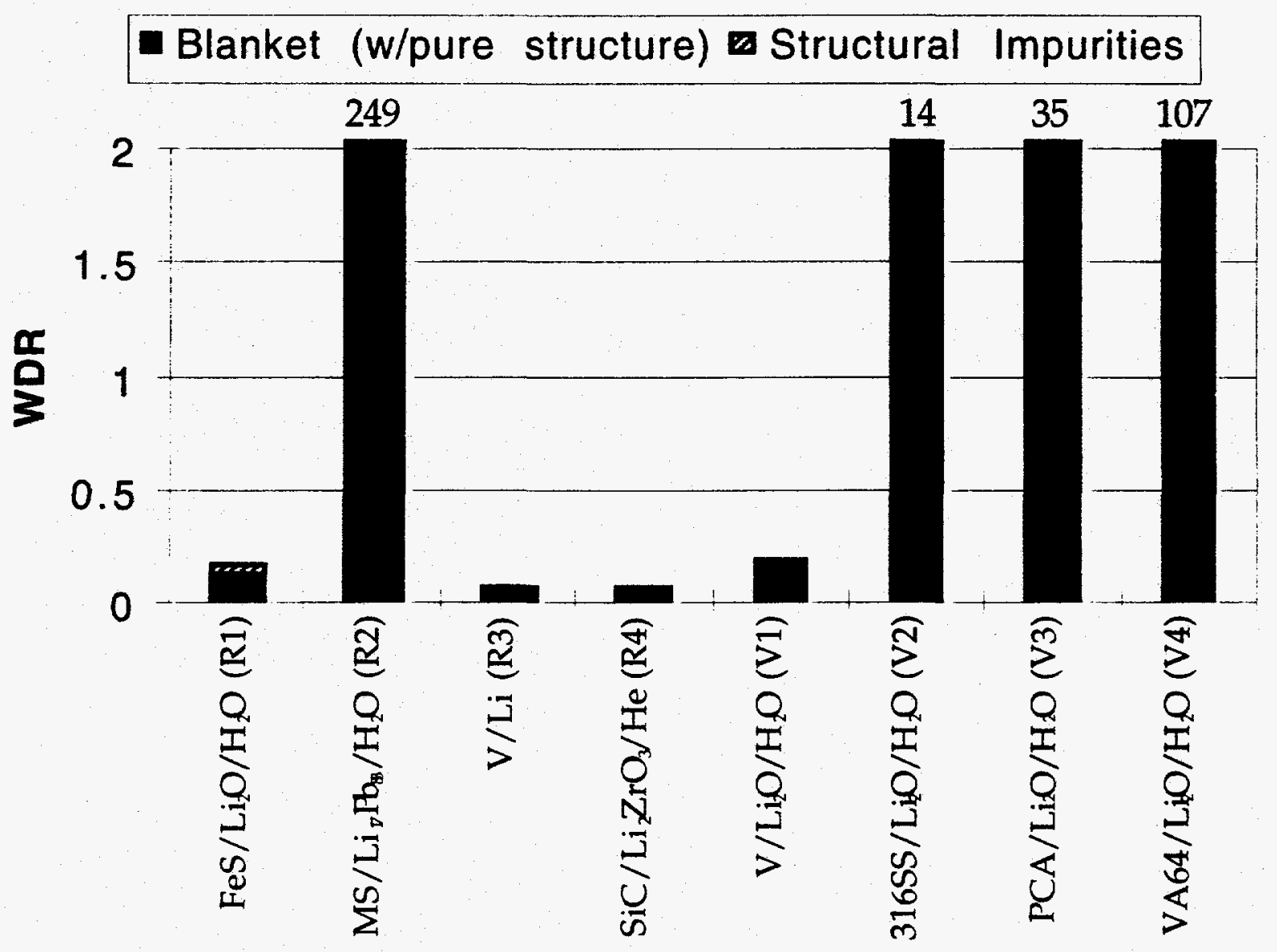

Figure 3

Comparison of Blanket Waste Disposal Ratings 


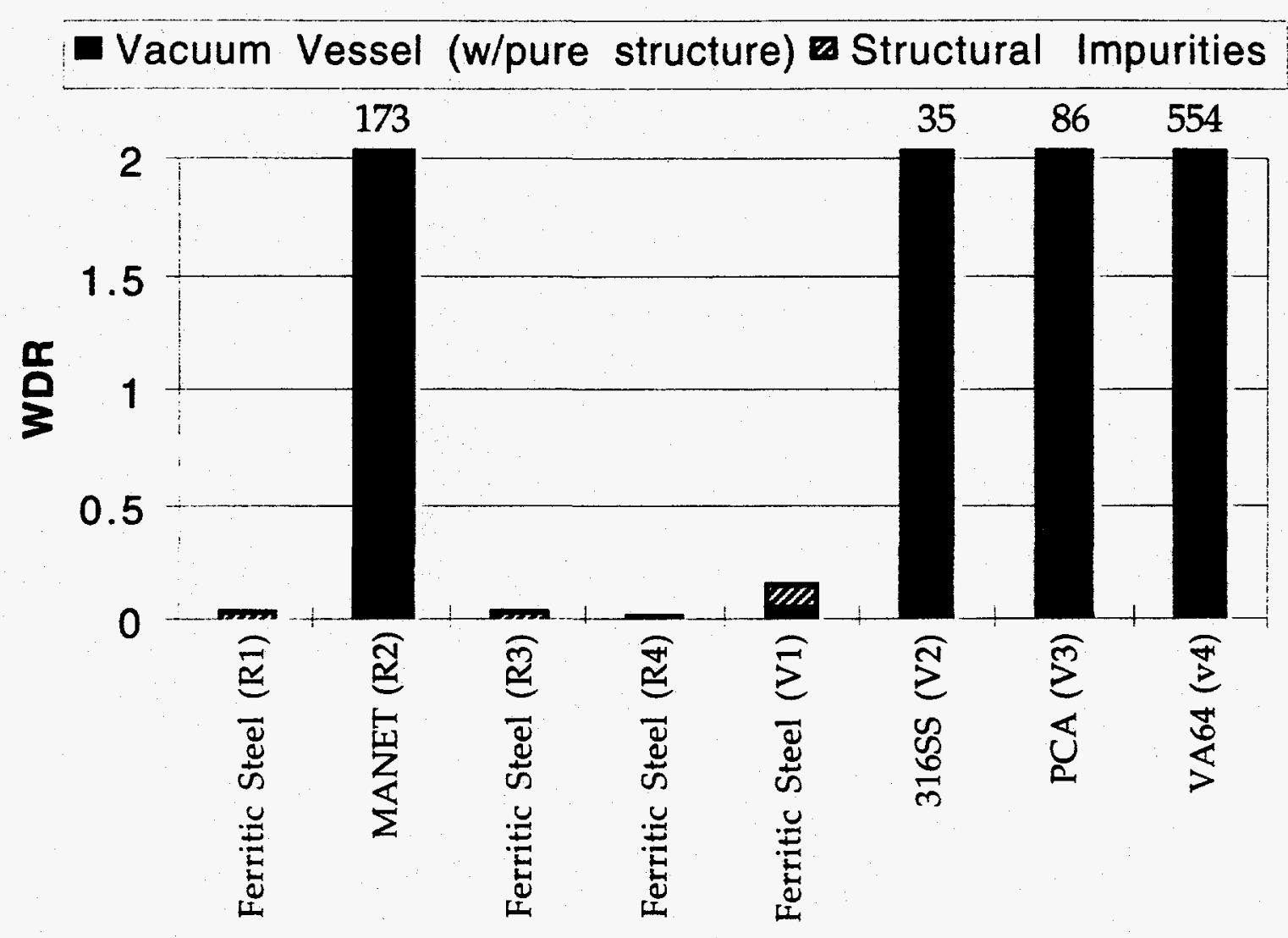

Figure 4

Comparison of Vacuum Vessel Waste Disposal Ratings 


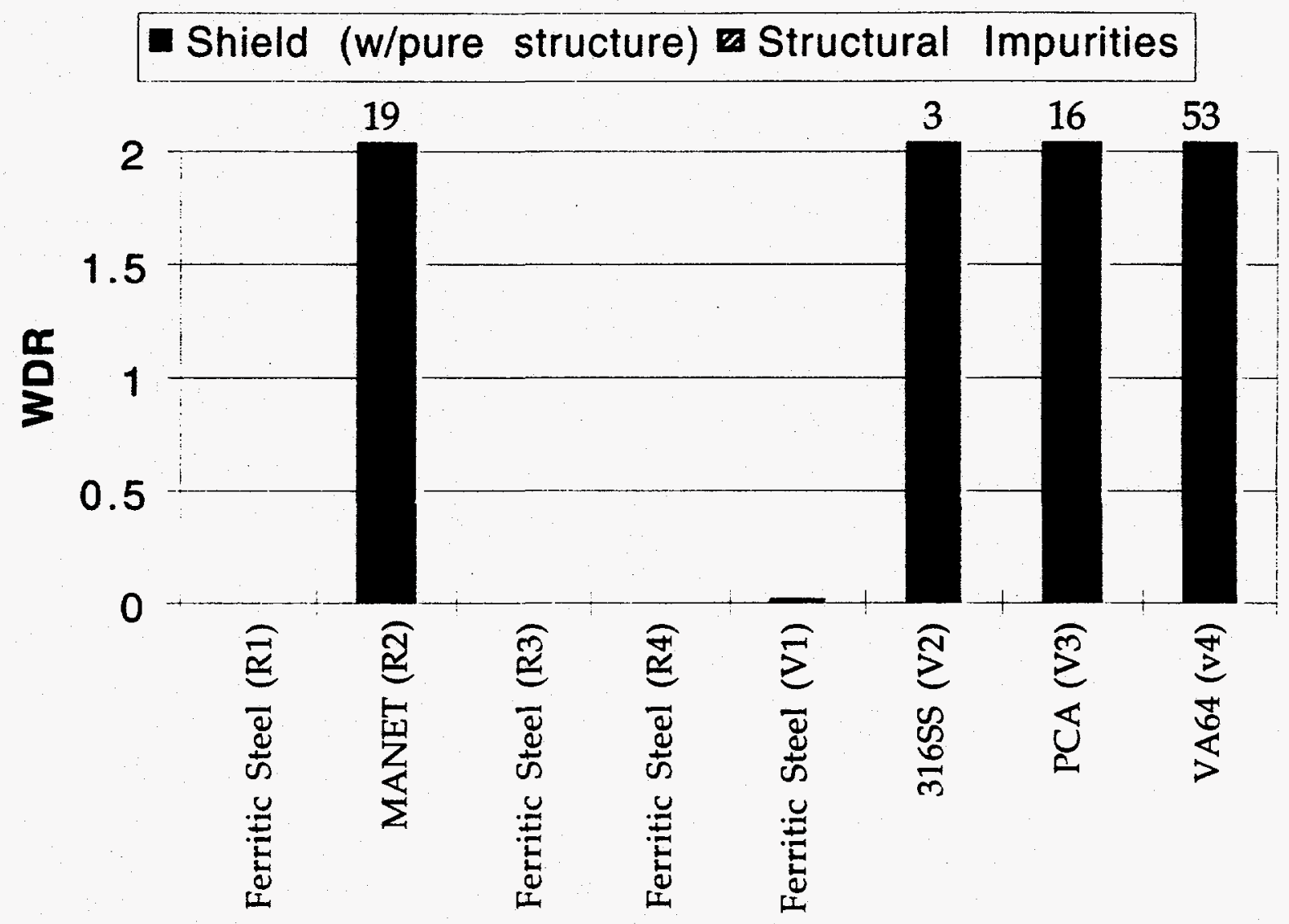

Figure 5

Comparison of Shield Waste Disposal Ratings 


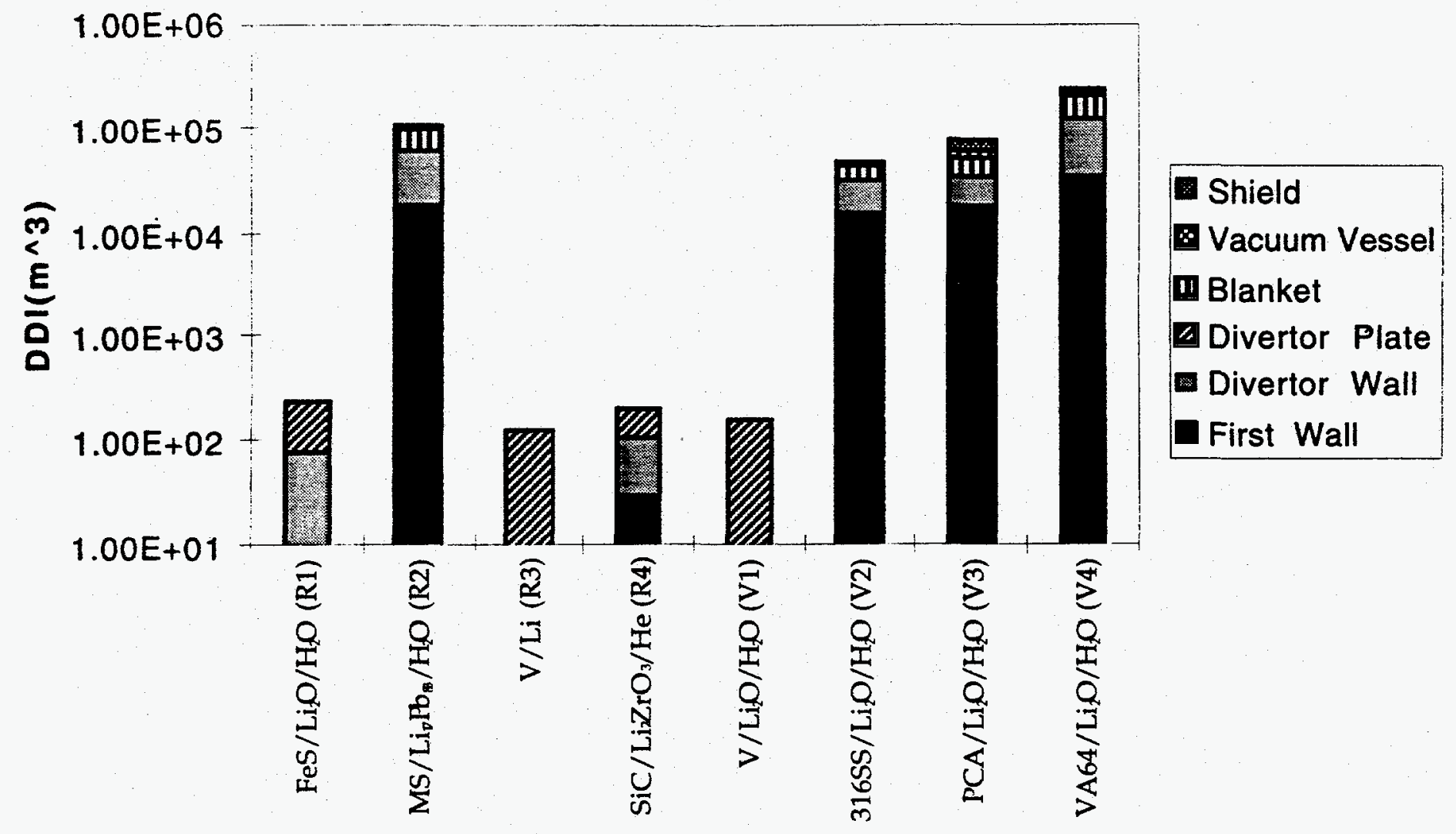

Figure 6

Comparison of Deep Disposal Indexes 
- First Wall (w/pure structure) $\mathbf{m}$ Structural Impurities
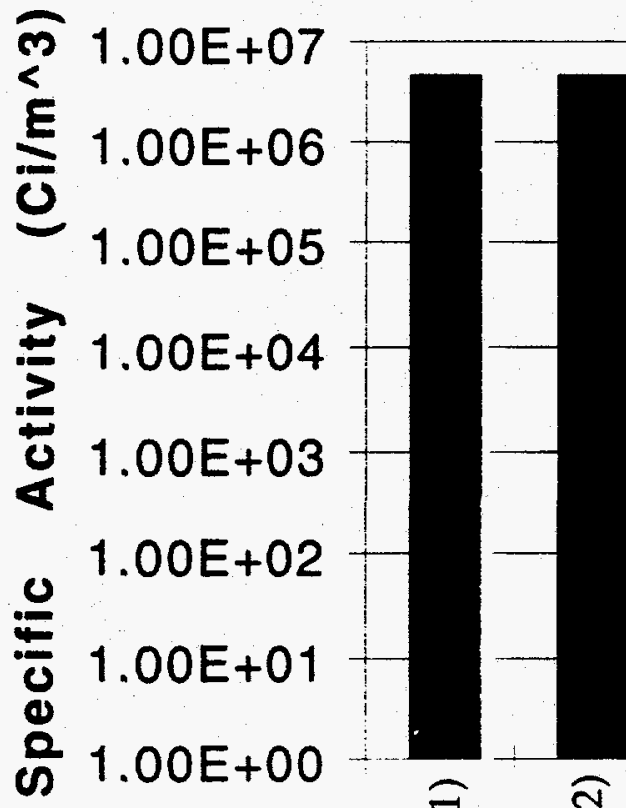

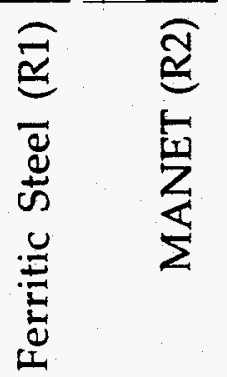
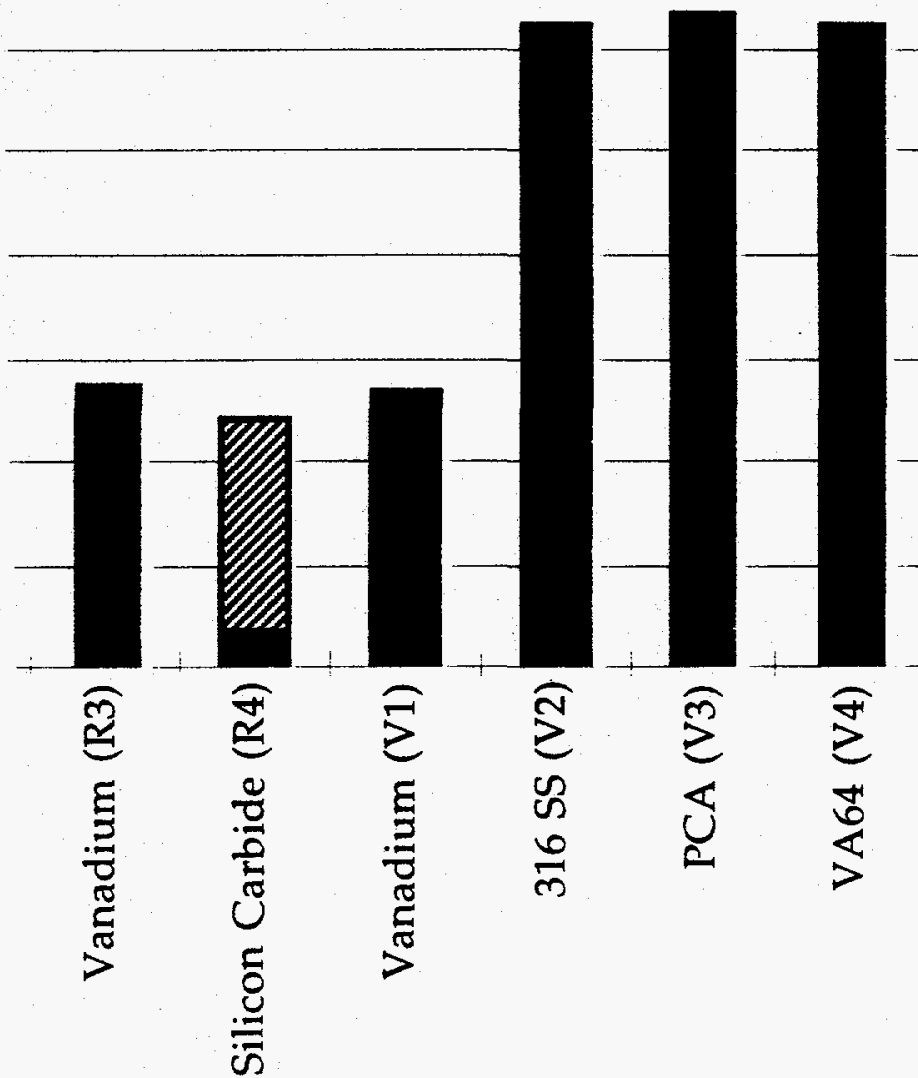

$\stackrel{0}{*}$

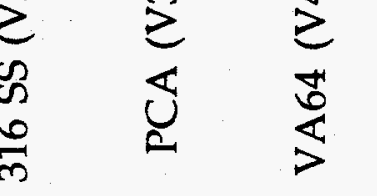

Figure 7

Comparison of First Wall Specific Activities (10 Years After Shutdown) 
- First Wall (w/pure structure) $\mathbf{m}$ Structural Impurities
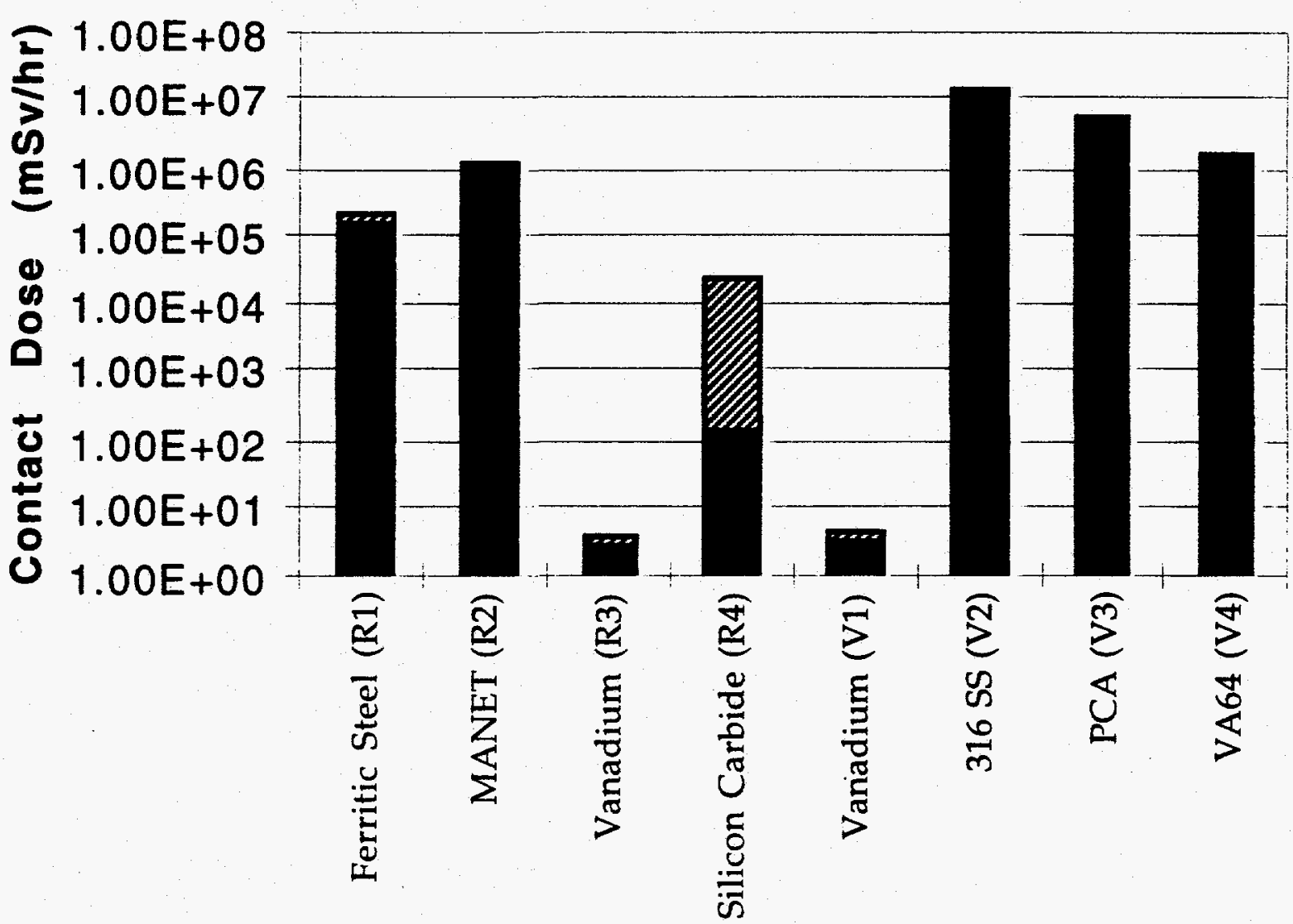

Figure 8

Comparison of First Wall Contact Doses

(10 Years After Shutdown) 


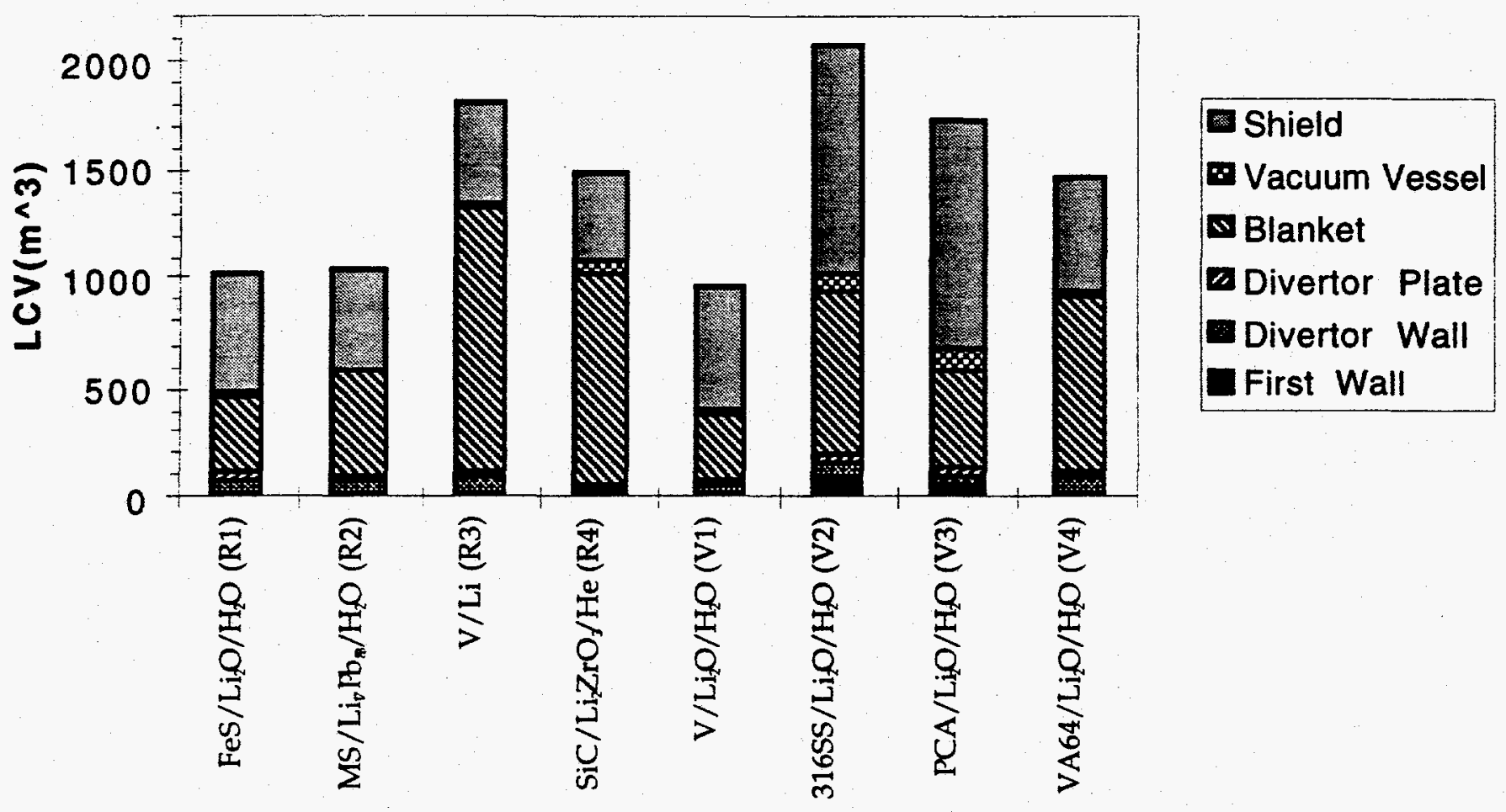

Figure 9

Comparison of Life Cycle Volumes 


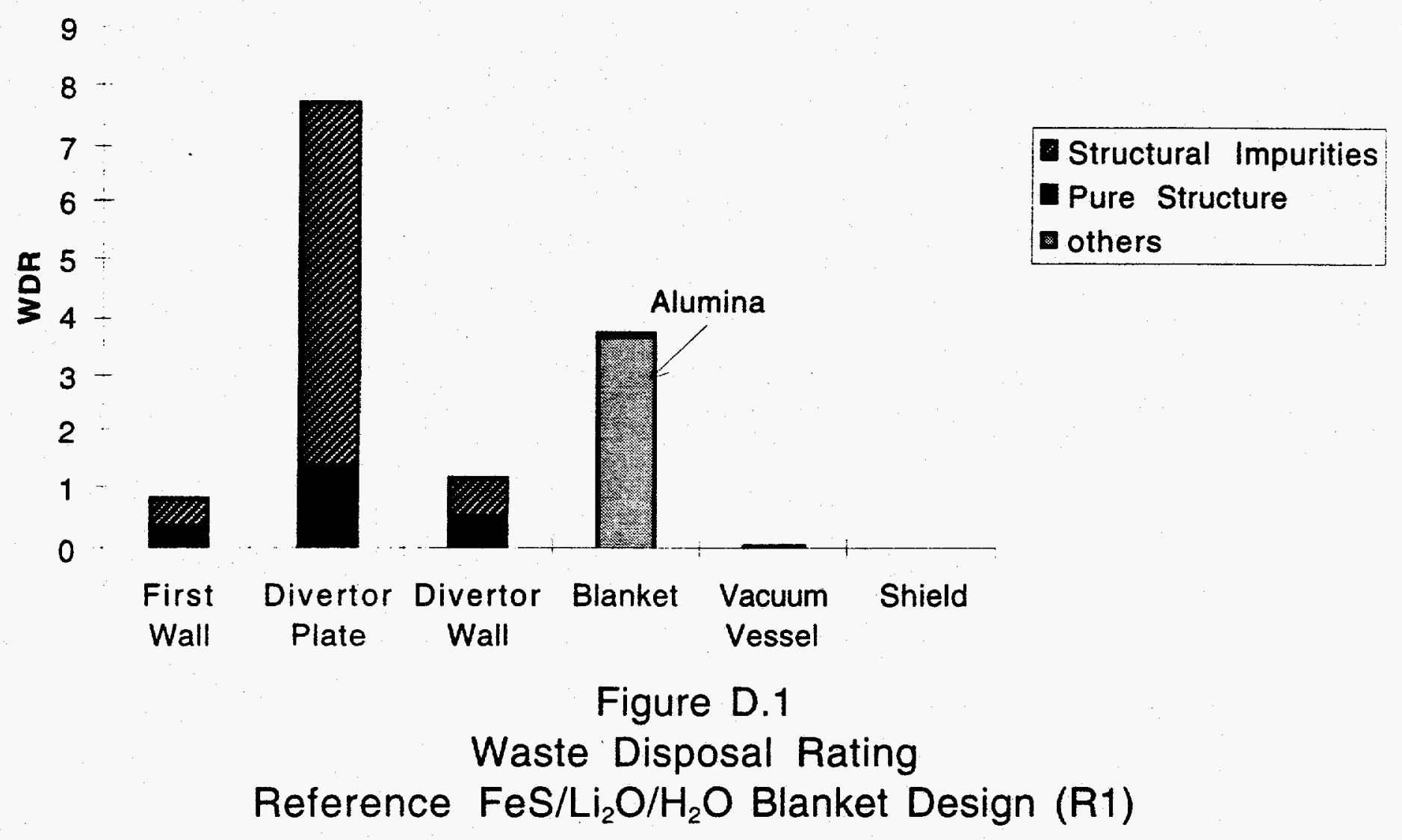




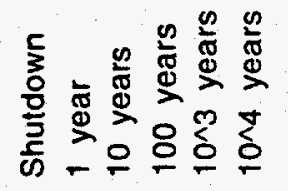

Pure Structure Structural Impurities DOthers

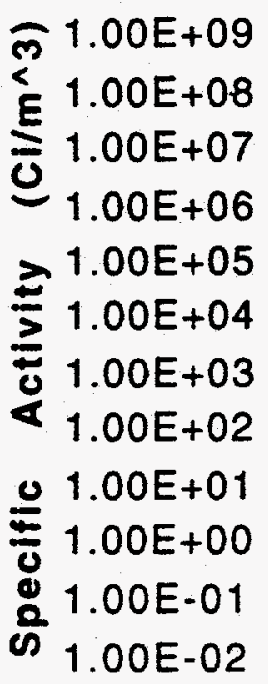

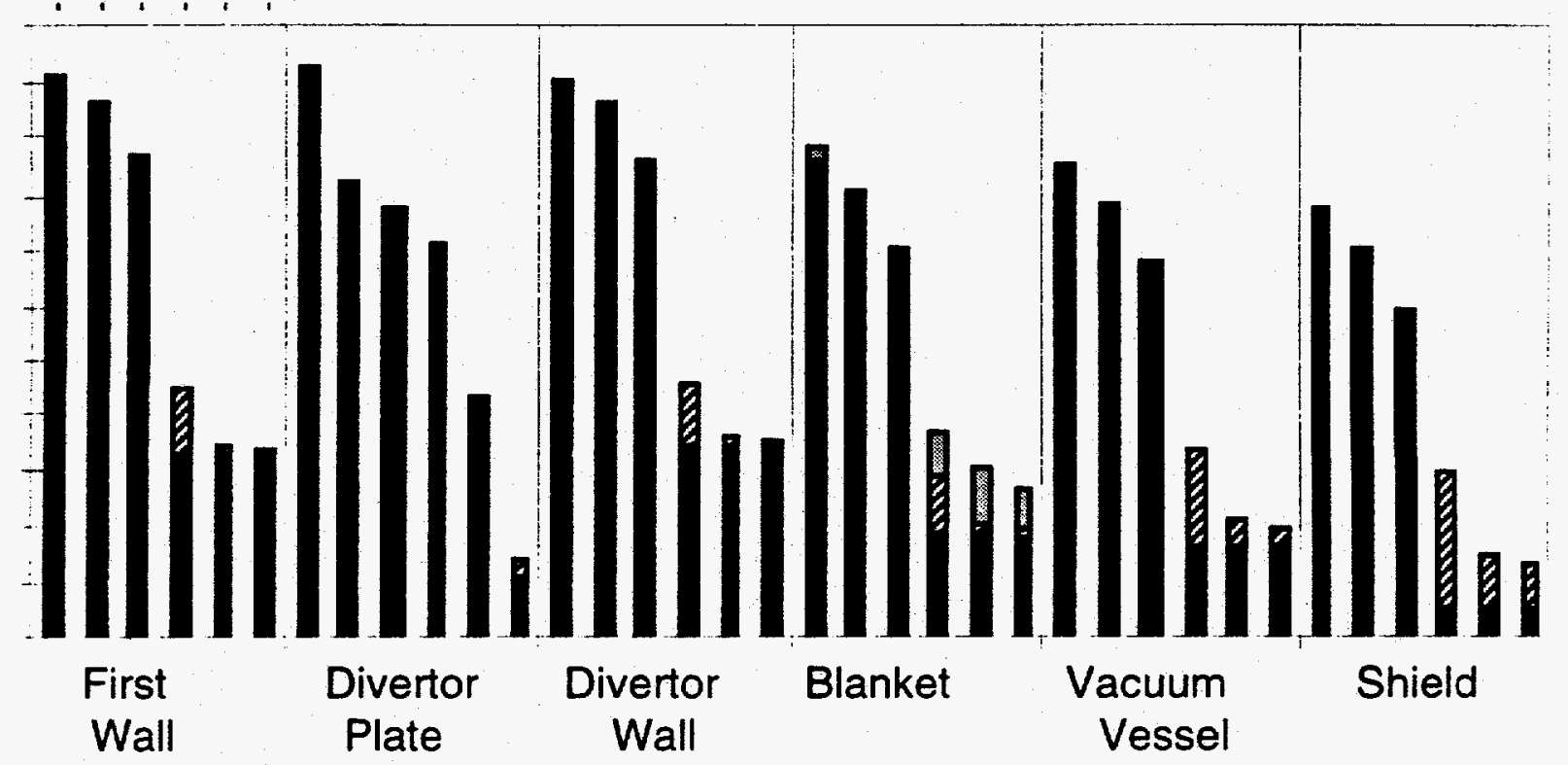

Figure D.2

Specific Activity

Reference $\mathrm{FeS} / \mathrm{Li}_{2} \mathrm{O} / \mathrm{H}_{2} \mathrm{O}$ Blanket Design (R1) 


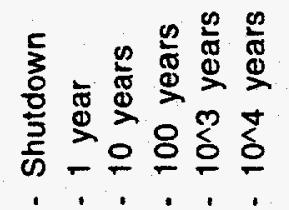

- Pure Structure Structural Impurites DOthers

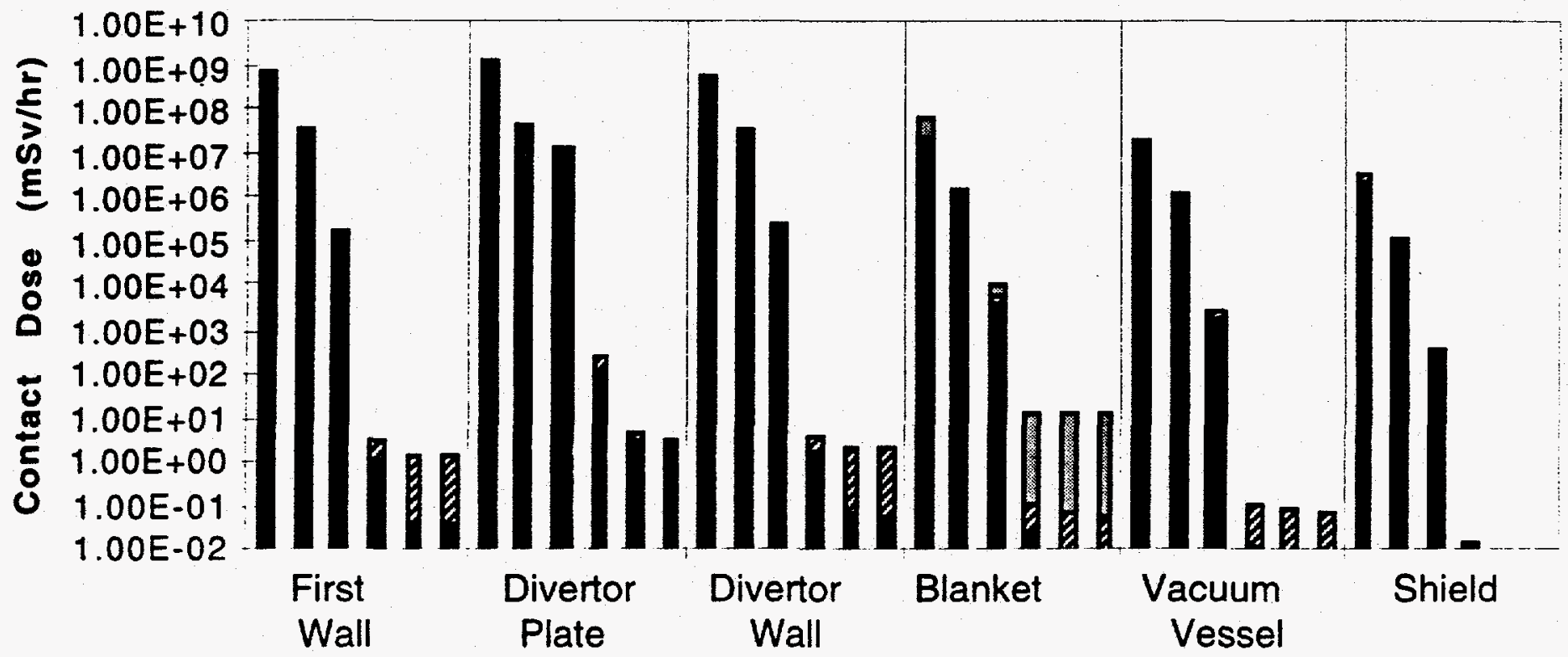

Figure D.3

Contact Dose

Reference $\mathrm{FeS} / \mathrm{Li}_{2} \mathrm{O} / \mathrm{H}_{2} \mathrm{O}$ Blanket Design (R1) 


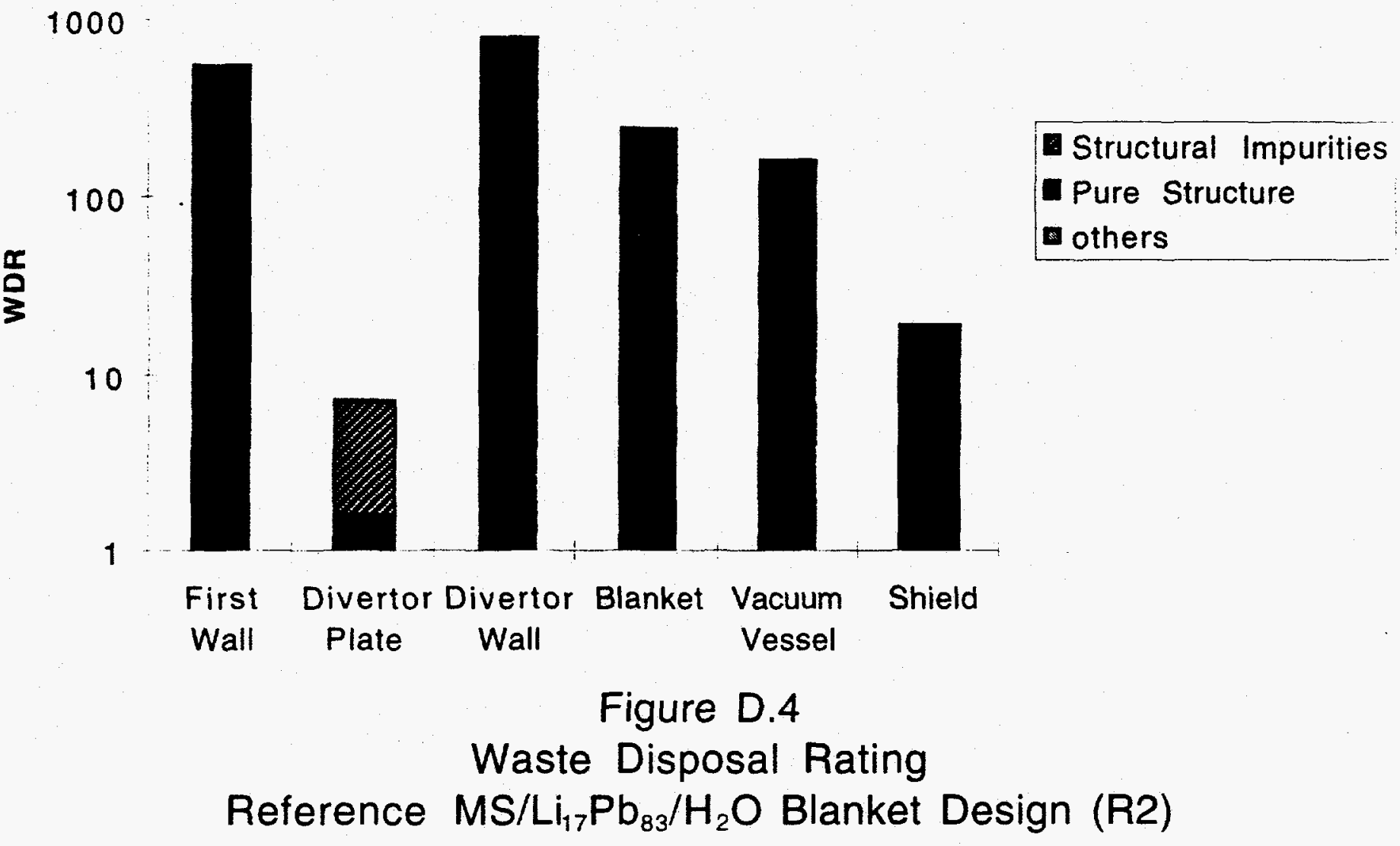




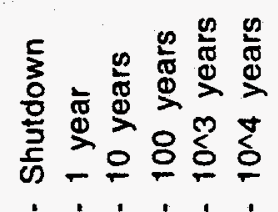

\section{Dure Structure Structural Impurities OOthers}
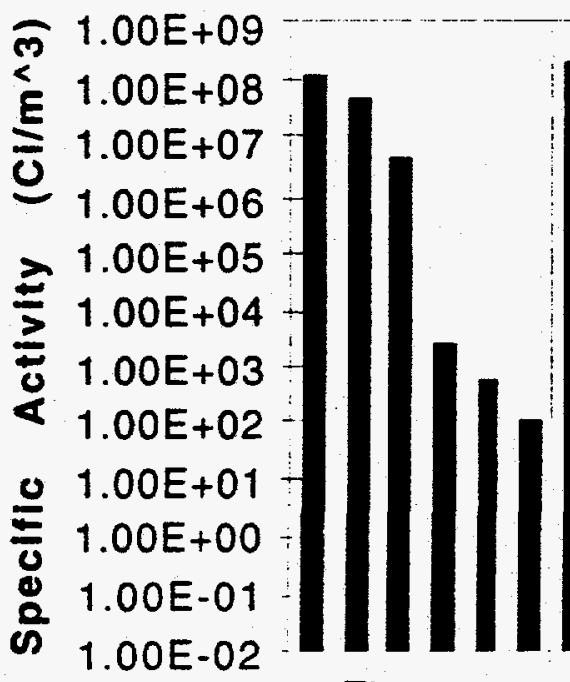

First

Wall

Divertor
Plate

Divertor

Wall

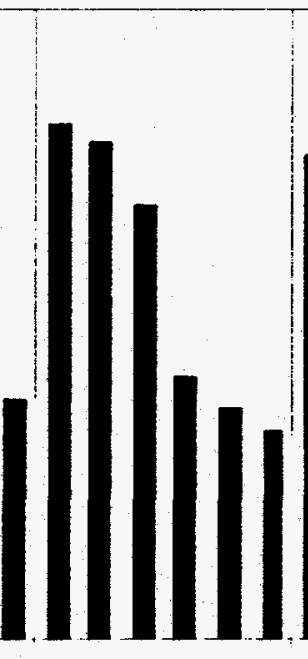

Blanket

Vacuum
Vessel

Figure D.5

Specific Activity

Reference $\mathrm{MS} / \mathrm{Li}_{17} \mathrm{~Pb}_{83} / \mathrm{H}_{2} \mathrm{O}$ Blanket Design (R2) 


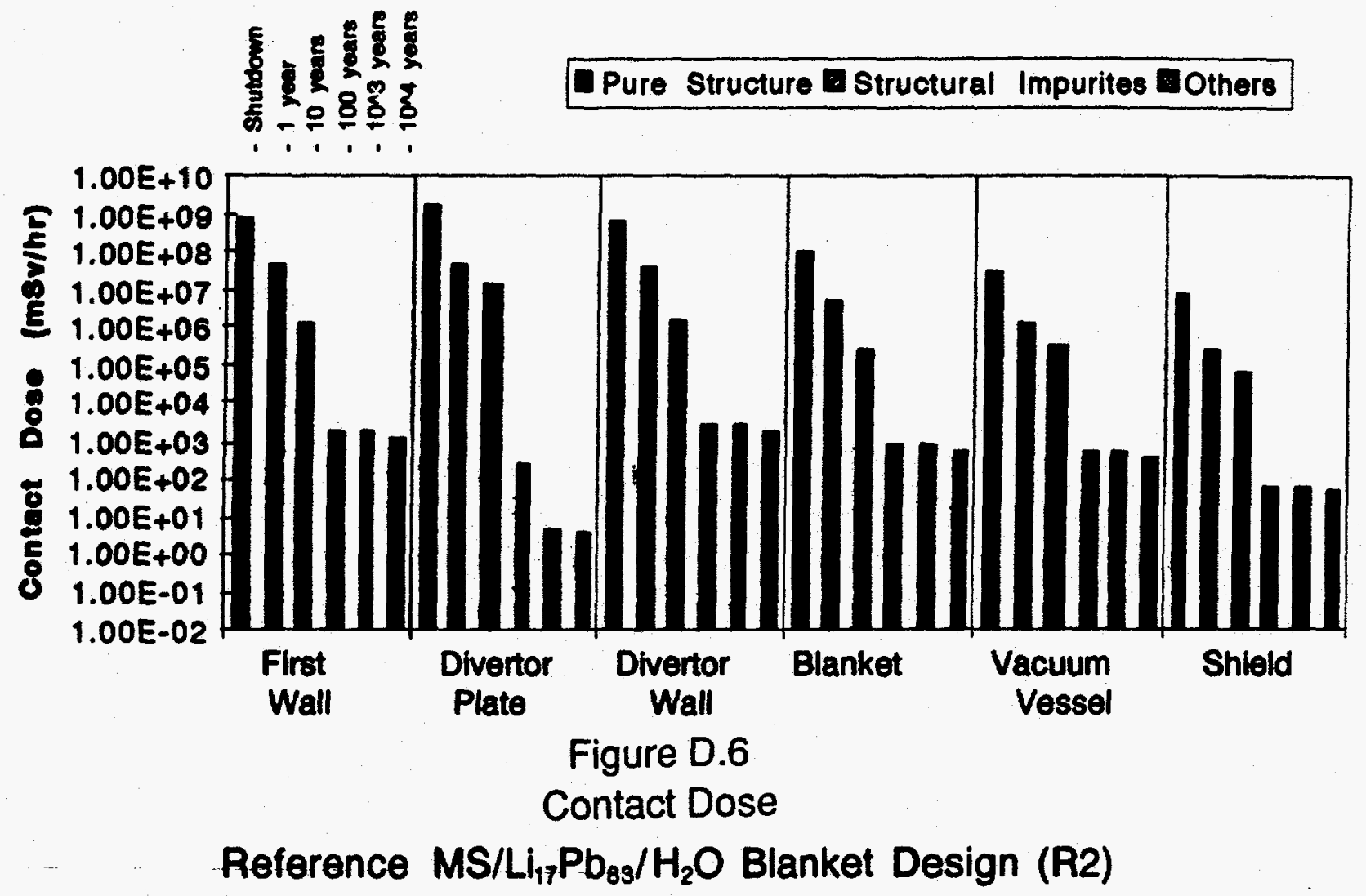




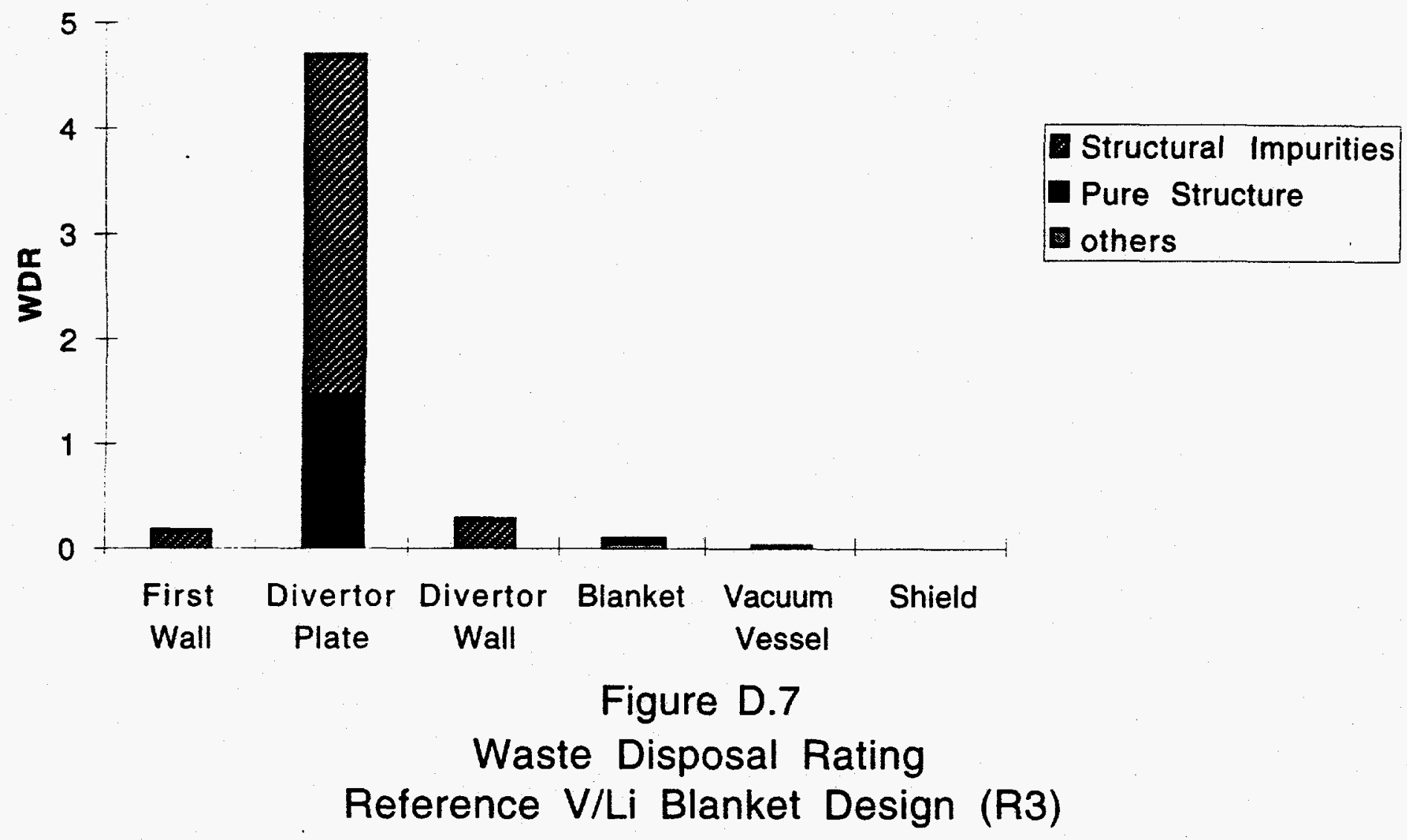




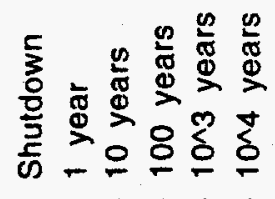

Pure Structure Structural Impurities Others
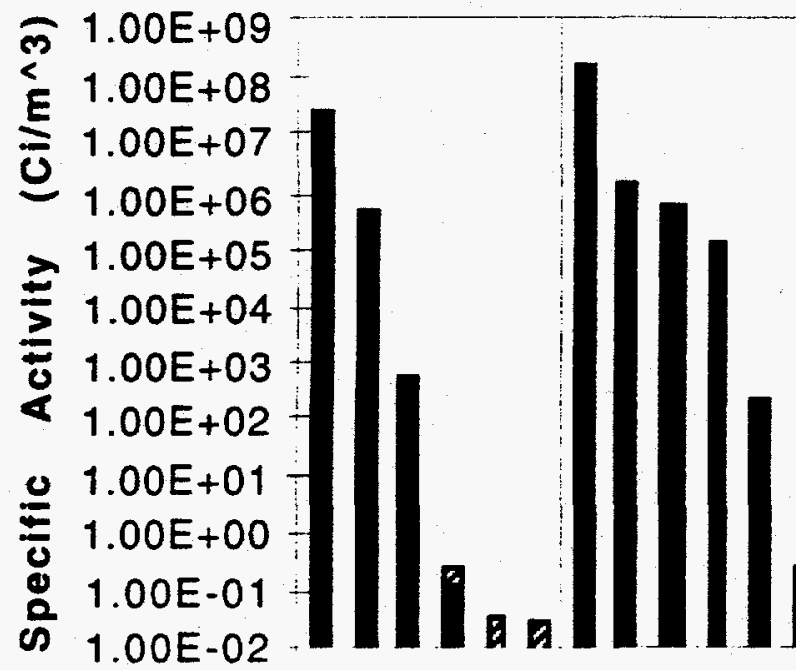

First

Wall

Divertor

Plate

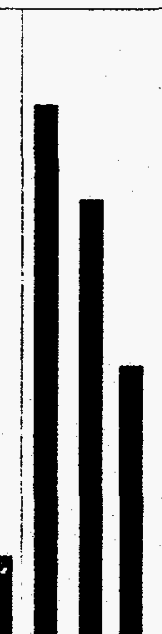

Divertor Wall

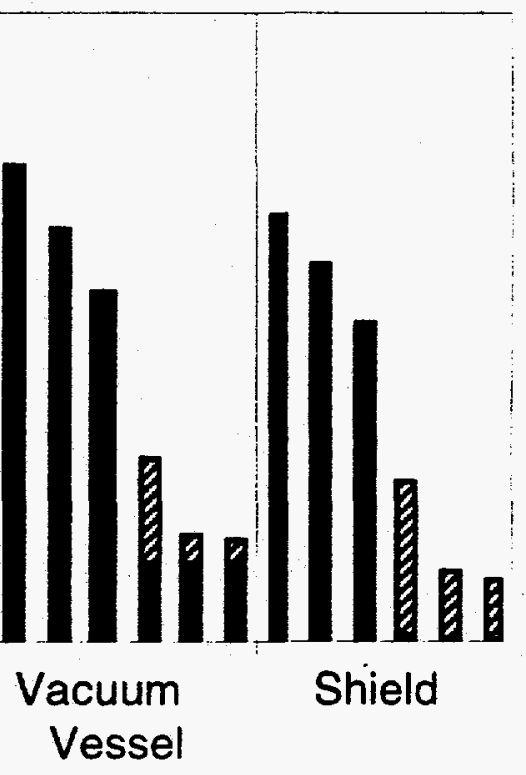

Figure D.8

Specific Activity 


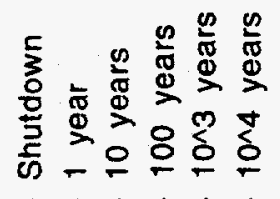

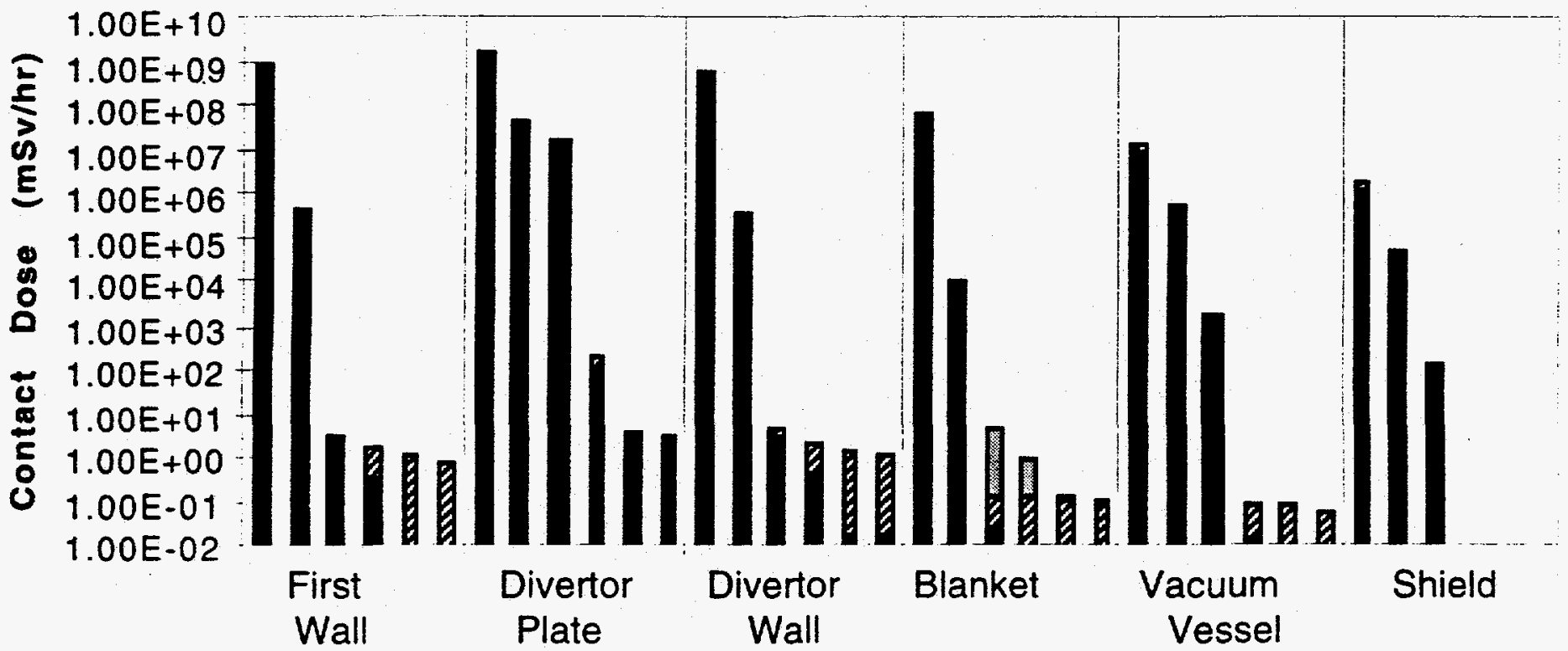

Figure D.9

Contact Dose

Reference V/Li Blanket Design (R3) 


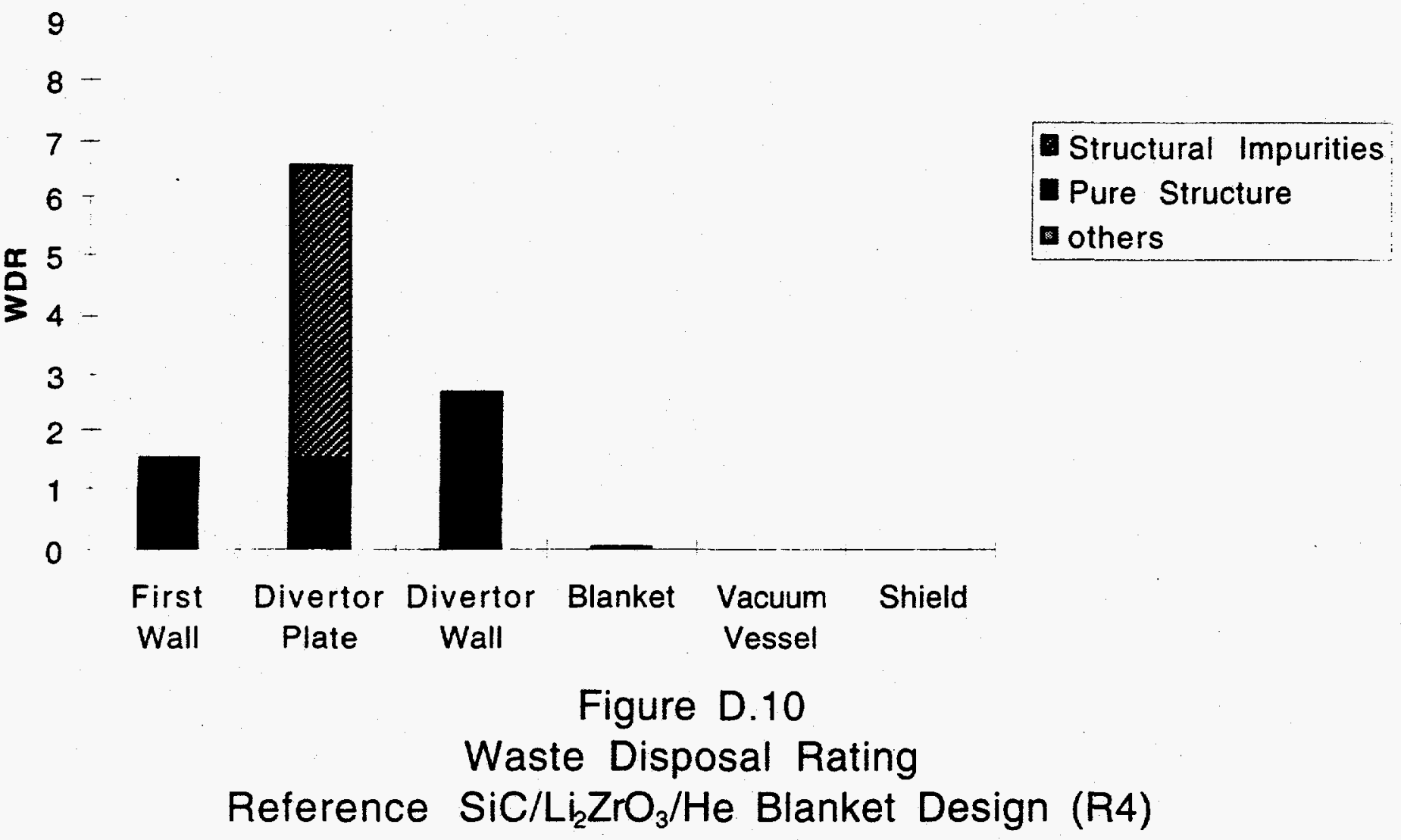




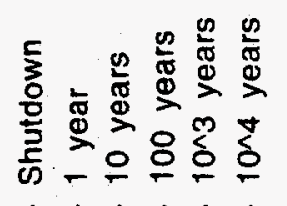

Pure Structure Structural Impurities Others

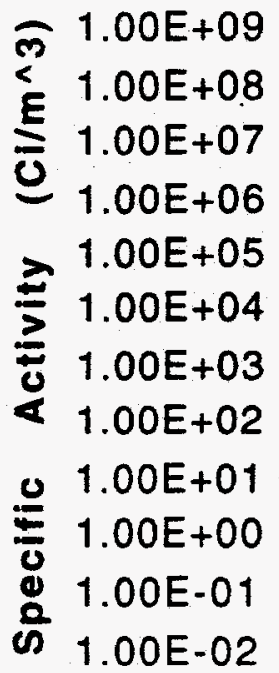

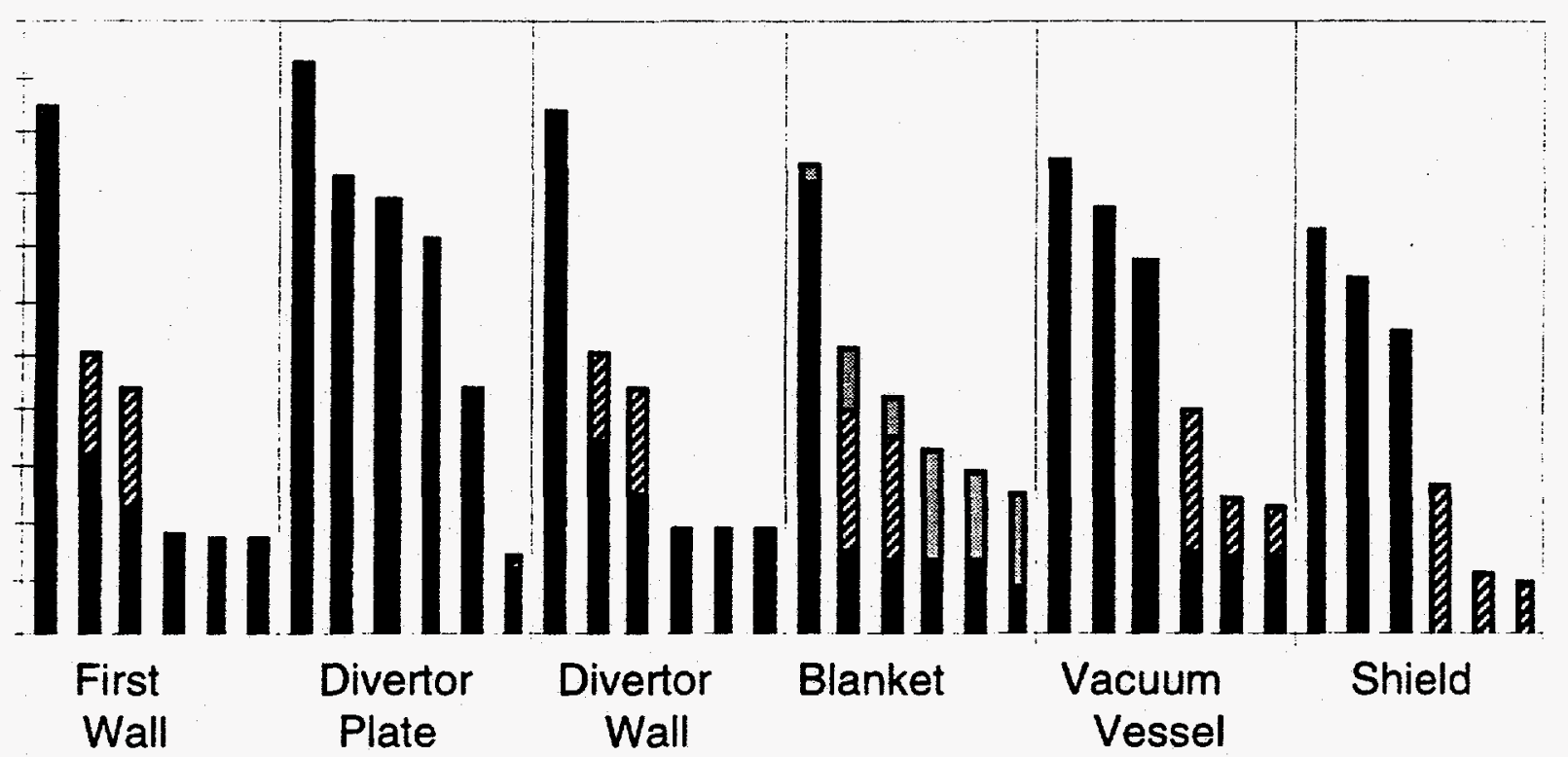

Figure D.11

Specific Activity

Reference $\mathrm{SiC} / \mathrm{Li}_{2} \mathrm{ZrO}_{3} / \mathrm{He}$ Blanket Design (R4) 


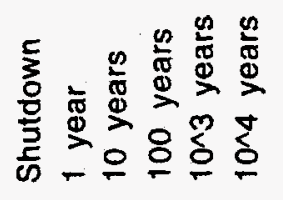

\section{Pure Structure Structural Impurites DOthers}

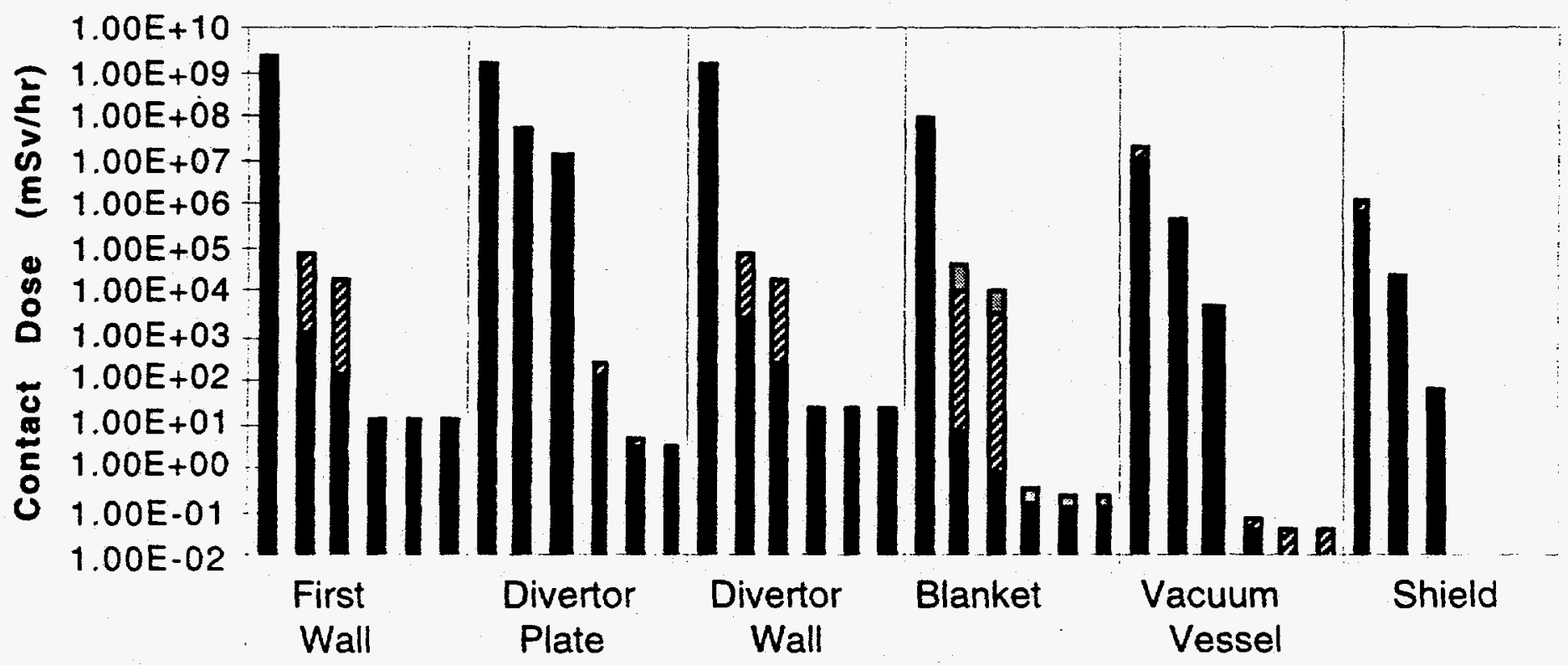

Figure D.12

Contact Dose

Reference $\mathrm{SiC} / \mathrm{Li}_{2} \mathrm{ZrO}_{3} / \mathrm{He}$ Blanket Design (R4) 


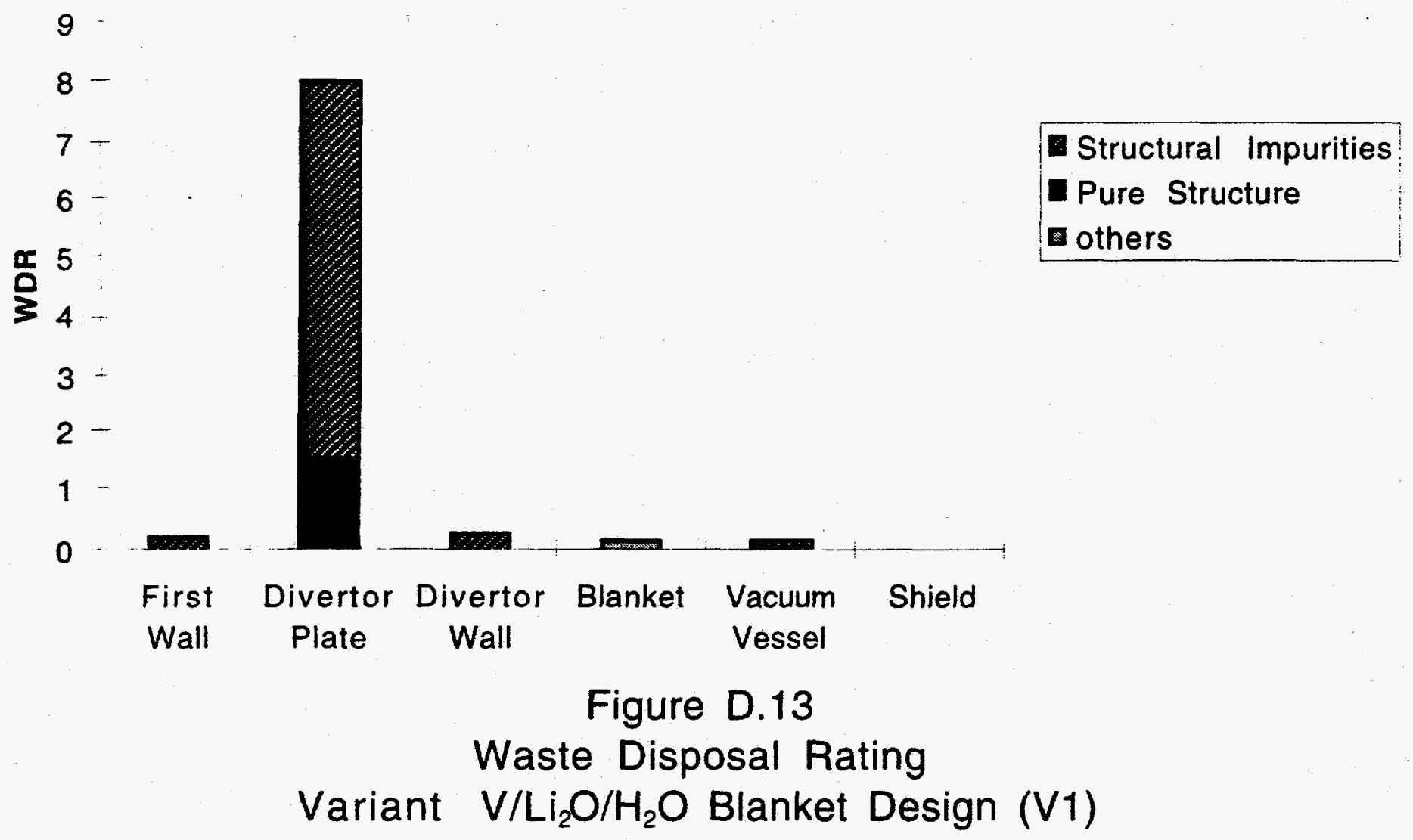




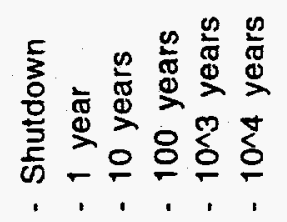

Pure Structure $\mathbf{D}$ Structural Impurities DOthers

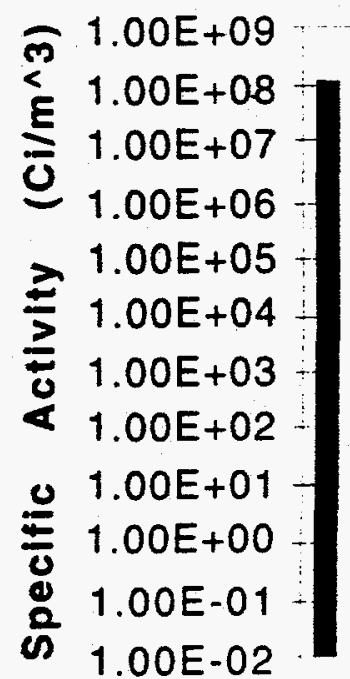

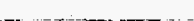




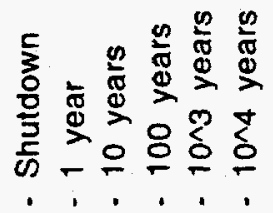

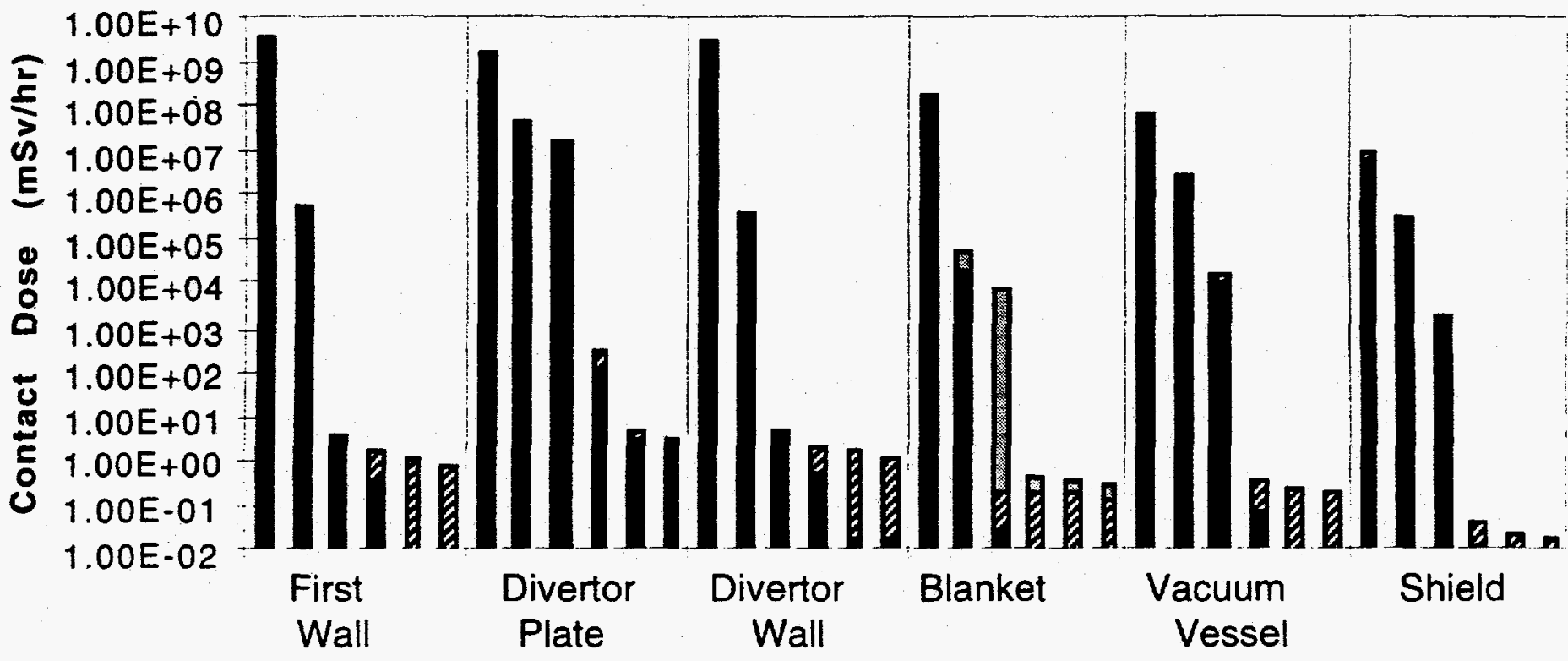

Figure D.15

Contact Dose

Variant $\mathrm{V} / \mathrm{Li}_{2} \mathrm{O} / \mathrm{H}_{2} \mathrm{O}$ Blanket Design (V1) 
1000

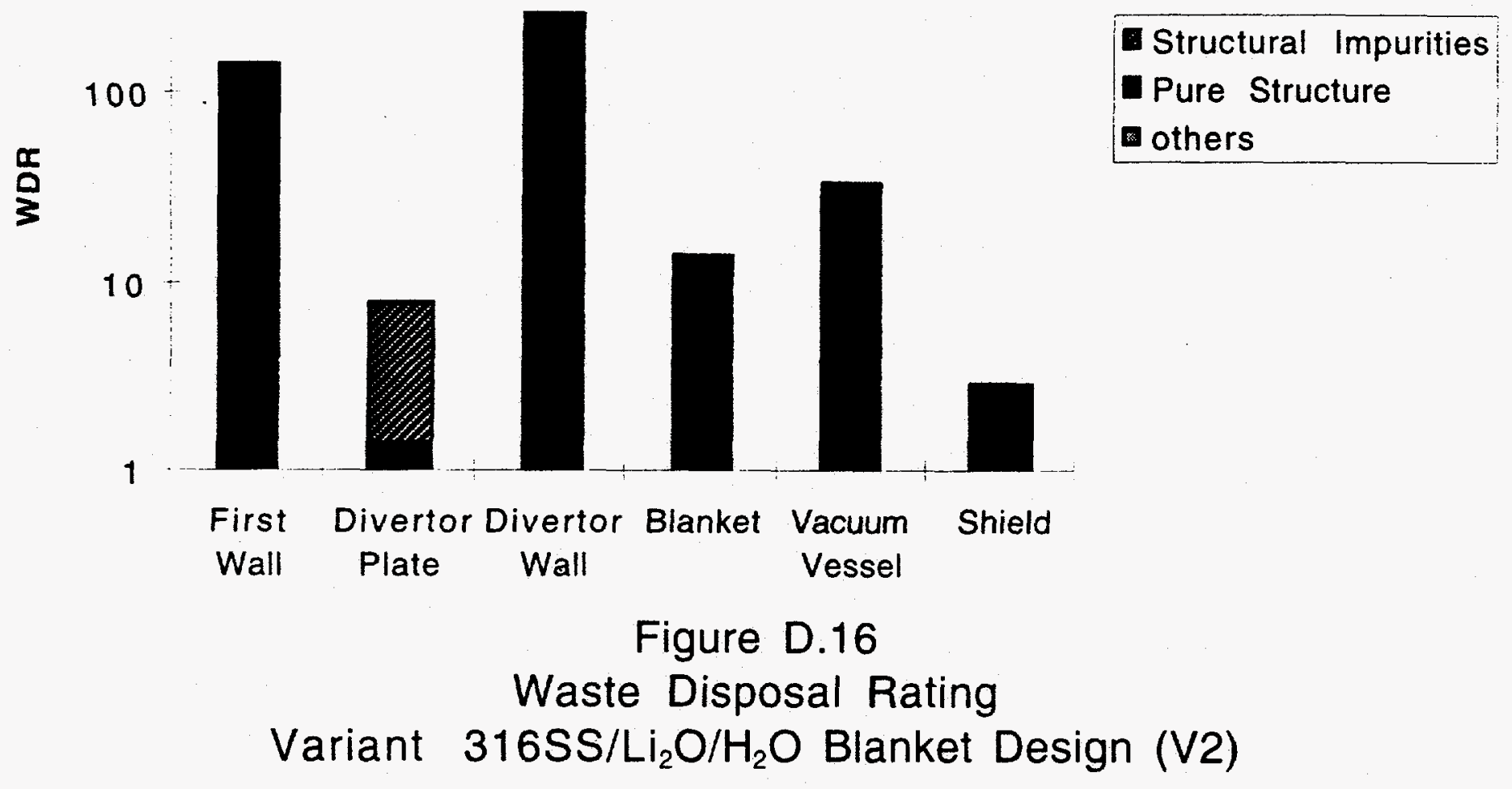




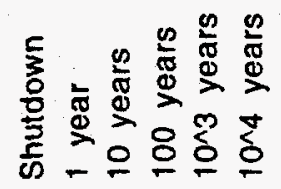

Pure Structure Structural Impurities Others

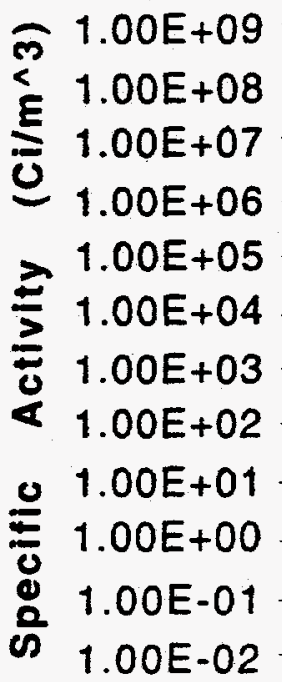

政

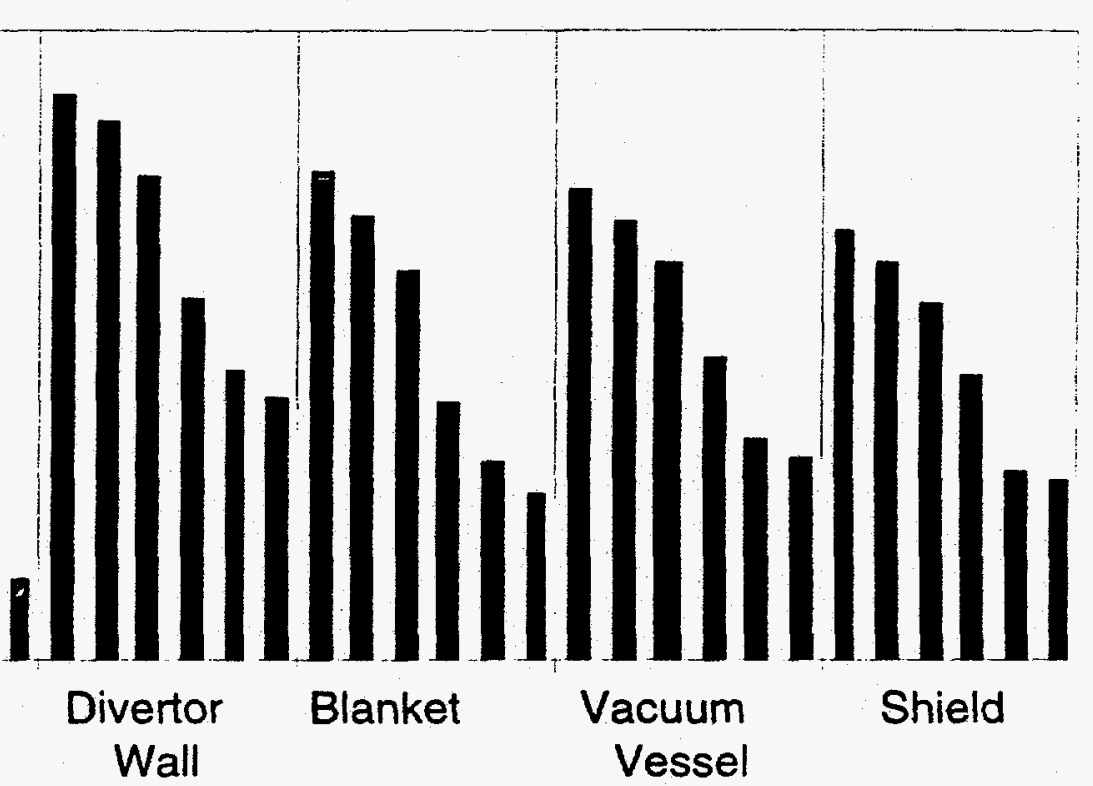

First

Wall

Divertor

Plate

Wall

Vessel

Figure D.17

Specific Activity

Variant $316 \mathrm{SS} / \mathrm{Li}_{2} \mathrm{O} / \mathrm{H}_{2} \mathrm{O}$ Blanket Design (V2) 


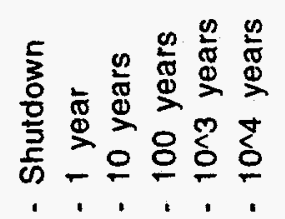

- Pure Structure $\mathbf{D}$ Structural Impurites Others

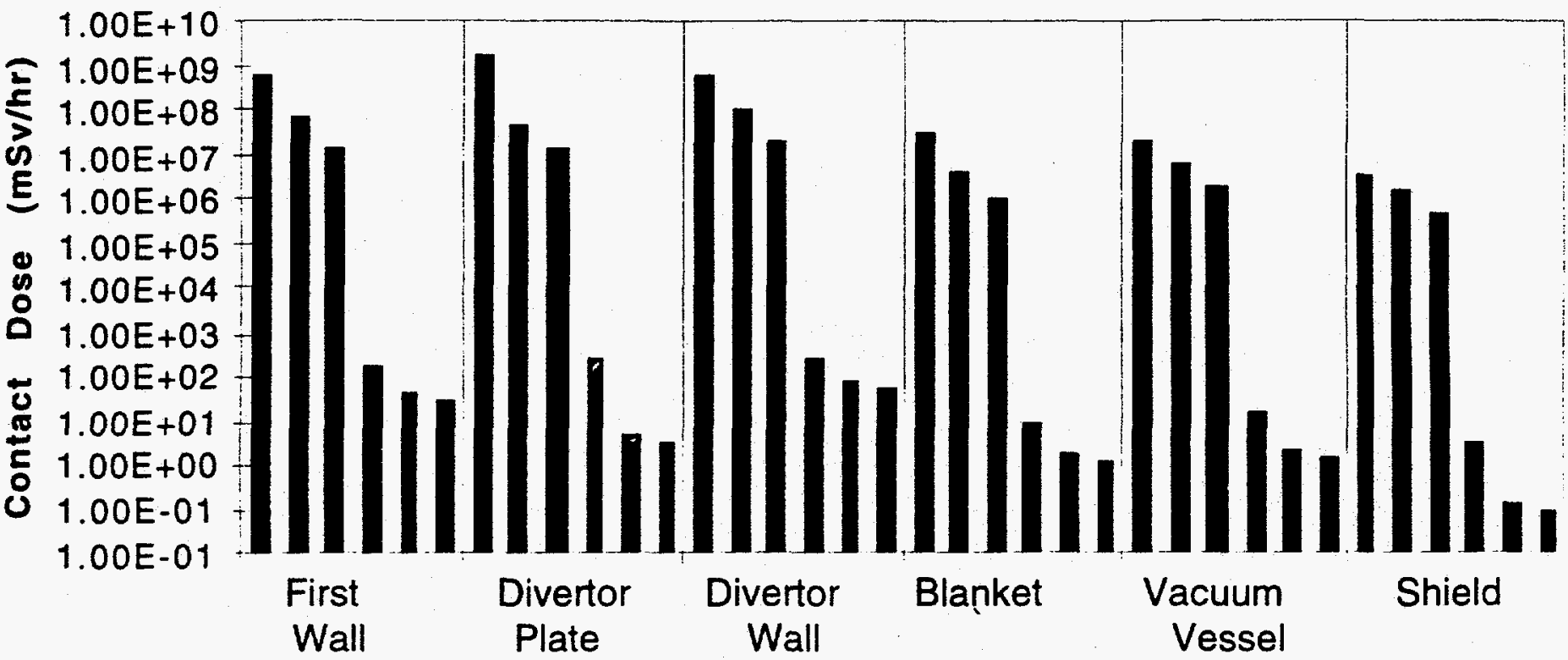

Figure D.18

Contact Dose

Variant $316 \mathrm{SS} / \mathrm{Li}_{2} \mathrm{O} / \mathrm{H}_{2} \mathrm{O}$ Blanket Design (V2) 